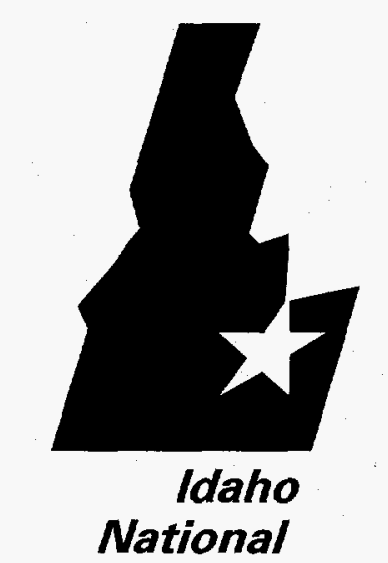

Engineering

Laboratory
INEEL/EXT-97-01113

Draft Final

May 1998
Radioactive Waste Management Complex Low-Level Waste Radiological Composite Analysis
J. M. McCarthy
B. H. Becker
S. O. Magnuson
K. N. Keck
T. K. Honeycutt

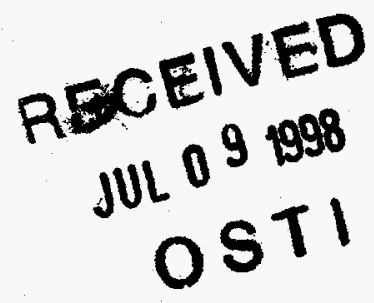




\section{DISCLAIMER}

This report was prepared as an account of work sponsored by an agency of the United States Government. Neither the United States Government nor any agency thereof, nor any of their employees, makes any warranty, express or implied, or assumes any legal liability or responsibility for the accuracy, completeness, or usefulness of any information, apparatus, product, or process disclosed, or represents that its use would not infringe privately owned rights. Reference herein to any specific commercial product, process, or service by trade name, trademark, manufacturer, or otherwise does not necessarily constitute or imply its endorsement, recommendation, or favoring by the United States Government or any agency thereof. The views and opinions of authors expressed herein do not necessarily state or reflect those of the United States Government or any agency thereof. 


\section{DISCLAIMER}

Portions of this document may be illegible in electronic image products. Images are produced from the best available original document. 
INEELIEXT-97-01113

Draft Final

\title{
Radioactive Waste Management Complex Low-Level Waste Radiological Composite Analysis
}

\author{
J. M. McCarthy \\ B. H. Becker \\ S. O. Magnuson \\ K. N. Keck \\ T. K. Honeycutt \\ Published May 1998

\begin{abstract}
Idaho National Engineering and Environmental Laboratory Integrated Earth Sciences Department Lockheed Martin Idaho Technologies Company Idaho Falls, Idaho 83415
\end{abstract} \\ Prepared for the \\ U.S. Department of Energy \\ Assistant Secretary for Environmental Management \\ Under DOE Idaho Operations Office \\ Contract DE-AC07-941D13223
}




\section{EXECUTIVE SUMMARY}

The Composite Analysis estimates the projected cumulative impacts to future members of the public from the disposal of low-level radioactive waste (LLW) at the Idaho National Engineering and Environmental Laboratory (INEEL) Radioactive Waste Management Complex (RWMC) and all other sources of radioactive contamination at the INEEL that could interact with the LLW disposal facility to affect the radiological dose. The impacts are compared with applicable U. S. Department of Energy (DOE) dose criteria as well as relevant U. S. Environmental Protection Agency (EPA) standards.

Based upon the Composite Analysis evaluation, waste buried in the Subsurface Disposal Area (SDA) at the RWMC is the only source at the INEEL that will significantly interact with the LLW facility. The source term used in the Composite Analysis consists of all historical SDA subsurface disposals of radionuclides as well as the authorized LLW subsurface disposal inventory and projected LLW subsurface disposal inventory. The Composite Analysis source term was developed from the contaminant inventory database for risk assessment (CIDRA) and subsequent modifications of CIDRA data for specific radionuclides.

Exposure scenarios evaluated in the Composite Analysis include the all-pathways and groundwater protection scenarios. The potential dose from gas-phase radionuclides in the air pathway has been shown to be negligible. Receptors are assumed to use groundwater from a well located at the INEEL boundary during the operations and institutional control period which ends in the year 2120 and at $100 \mathrm{~m}$ (328 ft) from the SDA facility boundary during post-institutional control. Potential cumulative health impacts from the active LLW disposal facility and all other sources of radioactive material in the ground that may interact with the LLW disposal facility are assessed for a hypothetical future member of the public. Figure 1 summarizes the exposure pathways evaluated for the Composite Analysis.

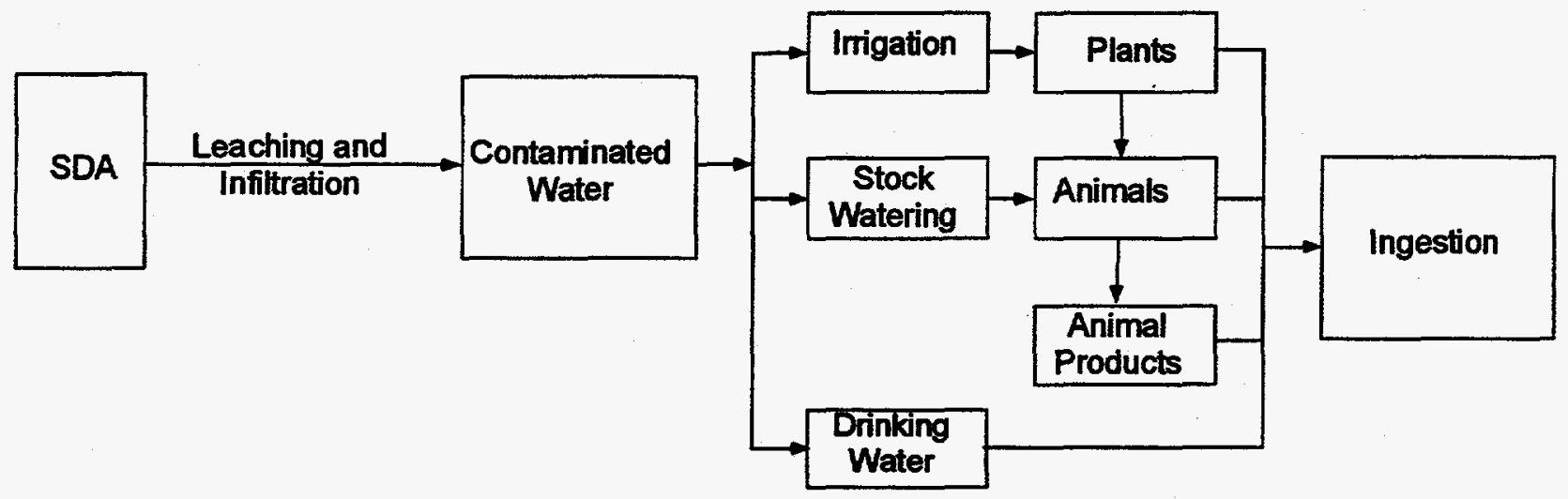

Figure 1. Exposure pathways at the RWMC considered in the Composite Analysis. 
All-pathways and groundwater doses to a hypothetical future member of the public were estimated for the following time periods:

- operational and institutional control period - present until the year 2120 , at the INEEL boundary.

- post-institutional control compliance period for approximately 1,000 years from present - year 2120 until the year $3000,100 \mathrm{~m}(328 \mathrm{ft})$ from the RWMC boundary.

The peak all-pathways dose for the period of institutional control for a member of the public located at the INEEL Site boundary is $0.06 \mathrm{mrem} / \mathrm{yr}$ occurring in the year 2120 . The dose calculations during the post-institutional compliance period for a member of the public located 100-m (328-ft) downgradient of the LLW facility is $58 \mathrm{mrem} / \mathrm{yr}$ occurring in the year 3000 . The primary radionuclides contributing to the dose are Np-237, U-234, U-238, and C-14. Table 1 presents the results of the Composite Analysis and compares them with the performance objectives for the all-pathways and groundwater protection scenarios.

The projected dose of $58 \mathrm{mrem} / \mathrm{yr}$ exceeds the Composite Analysis guidance dose constraint of 30 $\mathrm{mrem} / \mathrm{yr}$; therefore, an options analysis was conducted to determine the feasibility of reducing the projected annual dose. Three options for creating such a reduction were considered: (1) lowering infiltration of precipitation through the waste by providing a better cover, (2) maintaining control over the RWMC and portions of the INEEL indefinitely, and (3) extending the period of institutional control beyond the 100 years assumed in the Composite Analysis. Of the three options investigated, maintaining control over the RWMC and a small part of the present INEEL appears to be feasible and cost effective. 


\section{0}

Table 1. Comparison of results with performance objectives for all-pathways and groundwater protection.

\begin{tabular}{|c|c|c|c|}
\hline Performance objective & Regulatory reference & $\begin{array}{l}\text { Operational and institutional } \\
\text { control periods" }\end{array}$ & $\begin{array}{l}\text { Post-institutional control } \\
\text { period until the year } 3000^{b}\end{array}$ \\
\hline $\begin{array}{l}100 \mathrm{mrem} / \mathrm{yr} \text { (DOE primary dose limit) and } \\
30 \mathrm{mrem} / \mathrm{yr} \text { (CA dose limit for Options Analysis) }\end{array}$ & All-pathways ${ }^{c}$ & $0.23 \mathrm{mrem} / \mathrm{yr}$ & $58 \mathrm{mrem} / \mathrm{yr}$ \\
\hline 4 mrem/yr man-made beta-gamma EDE & Groundwater protection ${ }^{d}$ & $0.06 \mathrm{mrem} / \mathrm{yr}$ & $9.7 \mathrm{mrem} / \mathrm{yr}$ \\
\hline $20,000 \mathrm{pCi} / \mathrm{L}-3$ concentration & Groundwater protection ${ }^{d}$ & $6.5 \mathrm{pCi} /$ & $515 \mathrm{pCil}$ \\
\hline $8 \mathrm{pCi} / \mathrm{L} \mathrm{Sr}-90$ concentration & Groundwater protection ${ }^{d}$ & 4.9E-5 pCi/L & 1.7E-3 pCi/L \\
\hline $5 \mathrm{pCi} / \mathrm{La}-226$ and Ra-228 concentration & Groundwater protection & 3.5E-8 pCi/L & 3.2E-4 pCil \\
\hline $15 \mathrm{pC} / / \mathrm{L}$ gross alpha concentration & Groundwater protection ${ }^{6}$ & 6.0E-4 $\mathrm{pCi} / \mathrm{L}$ & $5.1 \mathrm{pCi} / \mathrm{L}$ \\
\hline $20 \mu \mathrm{g} / \mathrm{L}$ uranium concentration & Groundwater protection & $0.03 \mu \mathrm{g} / \mathrm{L}$ & $261 \mu \mathrm{g} / \mathrm{L}$ \\
\hline
\end{tabular}

a. During the operational and institutional control periods, from 1984 to 2120, the receptor is at the INEEL Site boundary.

b. During the post-institurtional control period, from 2120 to the year 3000 , the receptor is $100 \mathrm{~m}$ from the SDA boundary.

c. From the Composite Analysis Guidance Document, DOE, 1996.

d. Derived from current and proposed MCLs. 


\section{CONTENTS}

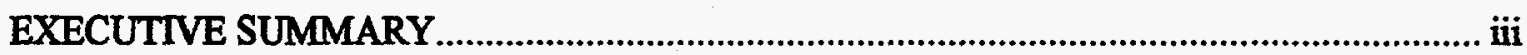

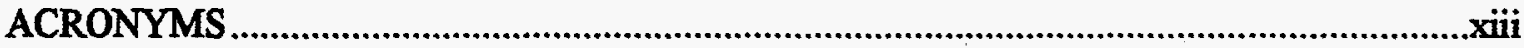

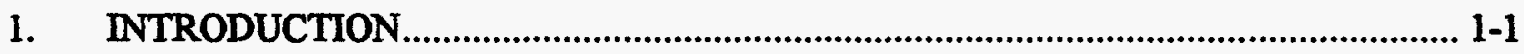

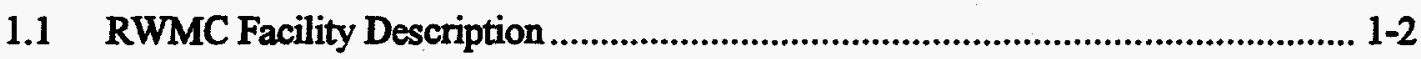

1.1.1 Past Disposal Practices..................................................................... 1-2

1.1.2 Disposal Practices Since 1985 ............................................................. 1-7

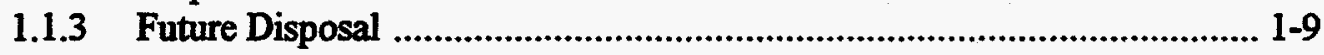

1.2 Potential INEEL Sources Which May Impact the Performance of the RWMC LLW Facility............................................................................1-10

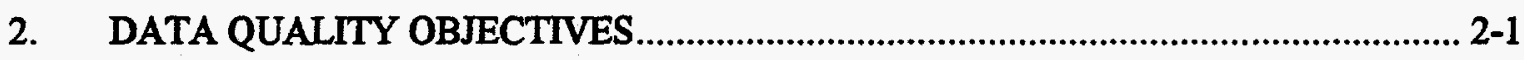

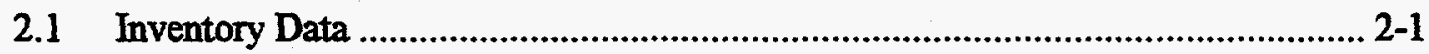

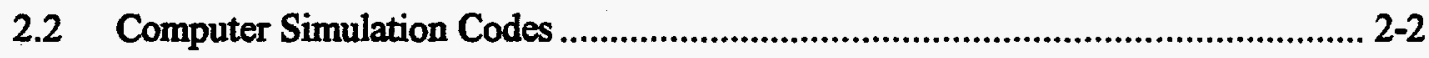

2.2.1 Source Term Release Simulation.................................................. 2-2

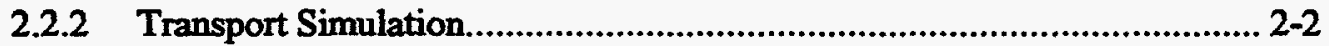

2.2.3 Radiation Physics Simulation ............................................................. 2-3

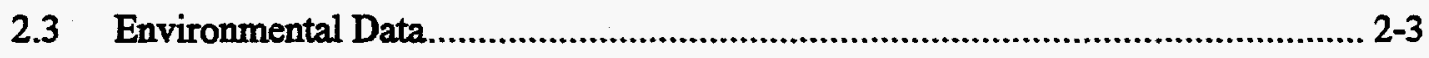

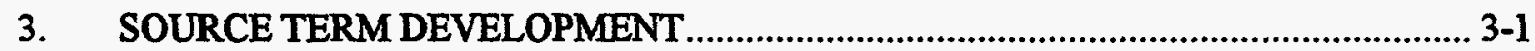

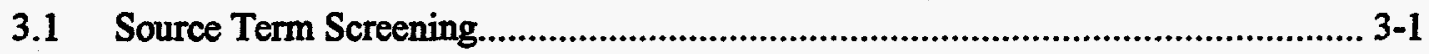

3.1.1 Contaminant Sources Outside the Upgradient Corridor........................... 3-1

3.1.2 Screening of Sources Within the Upgradient Corridor ............................. 3-4

3.1.3 Screening of Co-Located Facilities..................................................... 3-6

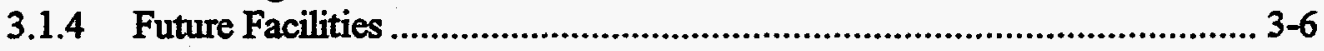

3.1.5 Summary of Source Term Screening .............................................. 3-6

3.2 Composite Analysis Source Term ................................................................ 3-7

4. COMPOSITE PERFORMANCE ANALYSIS .................................................... 4-1

4.1 Source Term Release and Transport.................................................... 4-1

4.1.1 Source Term Model ......................................................................... 4-1

4.1.2 Subsurface Model .........................................................................6

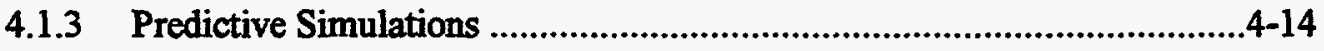

4.1.4 Composite Analysis Model ..........................................................14 
4.2 Exposure Scenarios

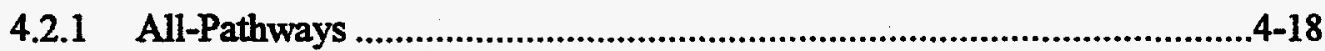

4.2.2 Groundwater Protection Scenario .................................................4-26

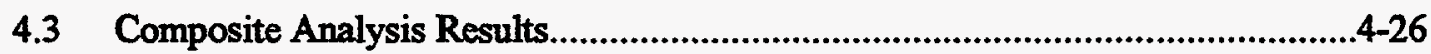

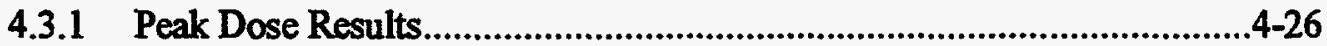

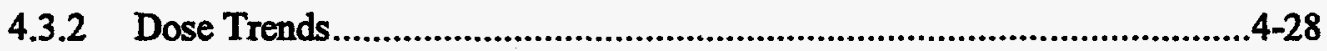

5. UNCERTAINTY AND SENSITIVITY ANALYSIS ............................................ 5-1

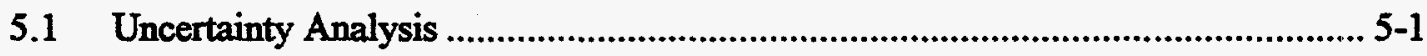

5.1.1 Source Term Uncertainty ........................................................... 5-1

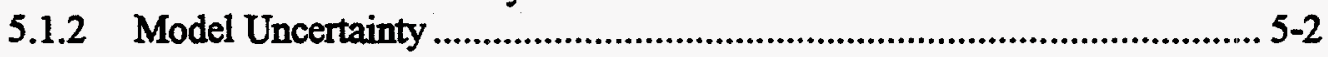

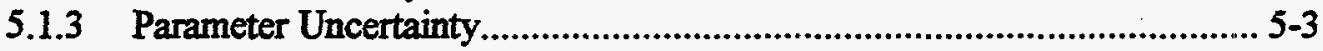

5.1.4 Dose Conversion Factor Uncertainty ................................................ 5-3

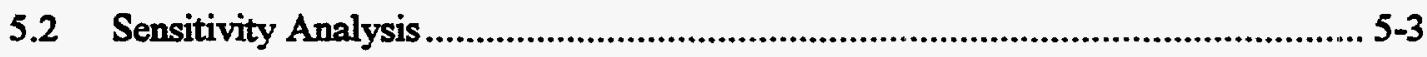

5.2.1 Model Sensitivity to Contaminant Mobility .......................................... 5-4

5.2.2 Model Sensitivity to Infiltration Rate ............................................... 5-7

5.2.3 Model Sensitivity to Contaminant Phase ............................................5-14

5.2.4 Model Sensitivity to Steel Corrosion Rate ..........................................5-14

5.2.5 Model Sensitivity Analysis Conclusions...........................................5-14

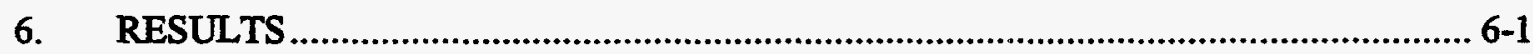

6.1 All-Pathways and Groundwater Protection.................................................... 6-1

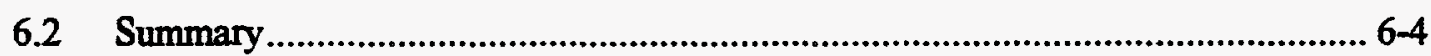

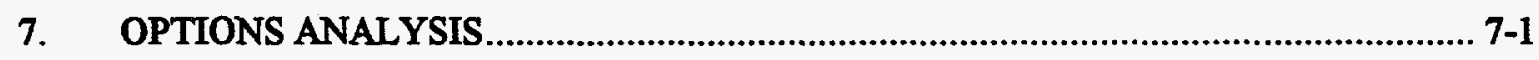

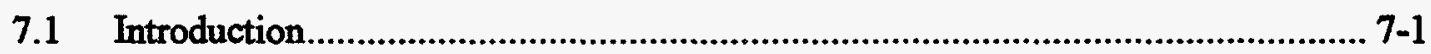

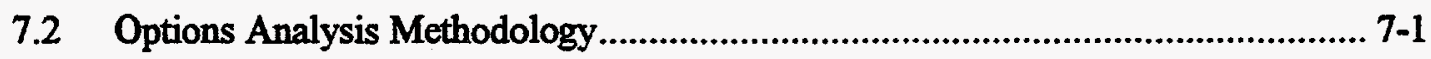

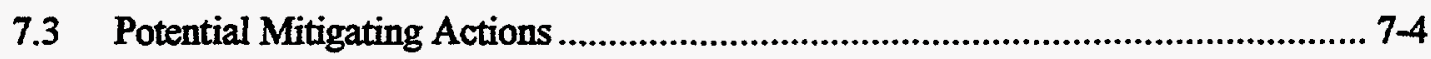

7.3.1 Reduced Infiltration .................................................................. 7-6

7.3.2 Maintaining Institutional Control ................................................... 7-7

7.3.3 Extend the Time of Institutional Control.............................................. 7-8

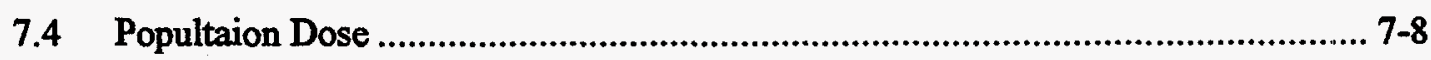

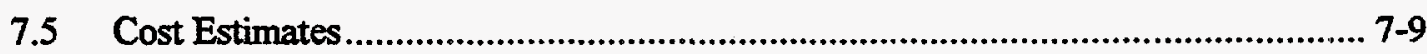


7.5.1 Cost of Reduced Infiltration ............................................................... 7-9

7.5.2 Cost of Maintaining Institutional Control ................................................ 7-9

7.6 ALARA Analysis ...................................................................................... 7-10

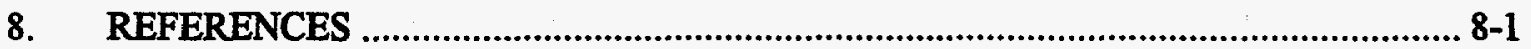

\section{FIGURES}

1-1. Location of the RWMC at the INEEL .................................................................. 1-3

1-2. Map of facilities within the RWMC......................................................................... 1-4

3-1. Groundwater flow paths at the INEEL .................................................................... 3-2

3-2. Corridor that defines the upgradient locations from which contamination will influence potential concentrations at the SDA .................................................................... 3-3

4-1. Distribution of three waste streams into the third level of grid refinement of the subsurface model

4-2. Simulated DUST source releases for uranium and other actinides .................................. 4-8

4-3. Simulated DUST source releases for I-129, Tc-99, and C-14 ........................................ 4-9

4-4. Assignment of variable surface infiltration inside the SDA ...........................................4-12

4-5. Numerical grid locations from which the peak aquifer concentrations were taken after the period of institutional control.

4-6. Comparison of the scaled Am-241 IRA doses with the Composite Analysis doses run using the best-estimate inventory.

4-7. Comparison of the scaled Tc-99 IRA doses with the Composite Analysis doses run using the best-estimate inventory

4-8. Exposure pathways at the RWMC considered in the Composite Analysis.

4-9. Total all-pathways and groundwater ingestion dose at $100 \mathrm{~m}$ downgradient from the SDA boundary during the 1,000 year compliance period

4-10. Total all-pathways dose and the major contributors to the all pathways dose at $100 \mathrm{~m}$ downgradient from the SDA boundary during the 1,000 year compliance period

4-11. Total groundwater ingestion dose and the major contributors to the total groundwater ingestion dose at $100 \mathrm{~m}$ downgradient from the SDA boundary during the 1,000 year compliance period. 
4-12. Total uranium concentration in groundwater at $100 \mathrm{~m}$ downgradient from the SDA boundary for the 10,000 years simulated

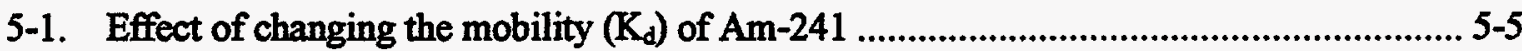

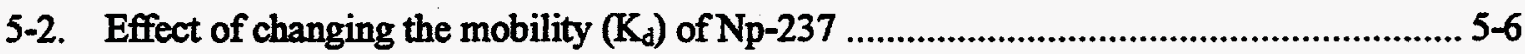

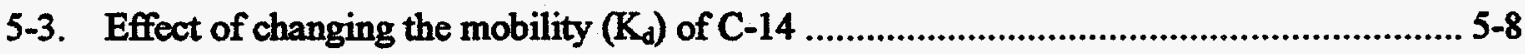

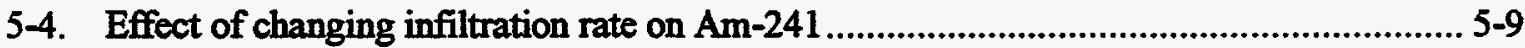

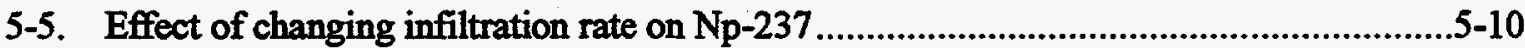

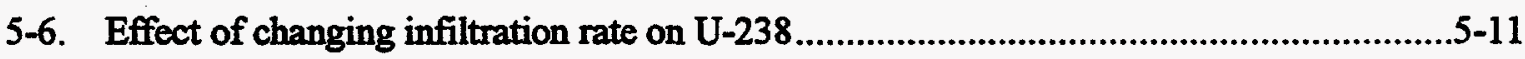

5-7. Simulated $\mathrm{U}-238$ concentrations $(\mathrm{pCi} / \mathrm{L})$ in the vadose zone immediately above the aquifer for the base and reduced infiltration cases.......................................5-13

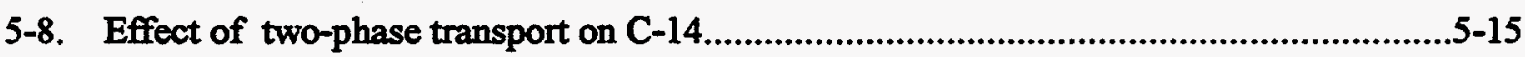

5-9. C-14 source releases, surface fluxes, and cumulative surface fluxes as a percentage of cumulative source releases for a range of partition coefficients in two-phase simulations

5-10. Effect of steel corrosion rate on C-14 dose

\section{TABLES}

3-1. Predicted peak doses south-west of the RWMC from the significant ICPP contaminants of potential concern.

3-2. RWMC (WAG-7) radionuclides of potential concern.

3-3. Composite Analysis source term inventory by date of disposal. 3-8

4-1. Release rate coefficients 4-4

4-2. Metal waste stream release mechanisms................................................................. 4-4

4-3. Percentage of contaminant disposal in resins....................................................... 4-5

4-4. Soil-to-water distribution coefficients used in modeling. 4-11

4-5. Scale factors used to convert the upper-bound doses to best-estimate doses. 4-16

4-6. Scale factor for daughter products. 4-17

4-7. Parameter values used in the all-pathways dose calculation. $. .4-22$ 
4-8. Peak dose $100 \mathrm{~m}$ downgradient of the SDA boundary during the 1,000 year compliance period

4-9. Peak dose $100 \mathrm{~m}$ downgradient of the SDA up to 10,000 years

$5-1 . \quad K_{d}$ values used in the mobility sensitivity cases................................................... $5-4$

5-2. Am-241 and Np-237 peak groundwater dose ..................................................... 5-7

5-3. Range of $K_{d}$ values used for $C-14$ and resulting peak .......................................... 5-7

5-4. Dose (mrem/yr) at two receptor locations for base and reduced infiltration cases...........5-14

5-5. Comparison of the single-phase $\mathrm{C}-14$ doses to the dual-phase $\mathrm{C}-14$ doses ....................5-17

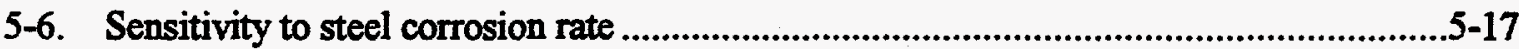

6-1. Comparison of results with performance objectives for all-pathways and groundwater protection.

7-1. Radionuclides considered in the Options Analysis

7-2. Radionuclide release model

7-3. Ingestion dose conversion factors used in the Options Analysis.

7-4. Physical dimensions used in the Options Analysis

7-5. Vadose zone distribution coefficients.

7-6. Aquifer solubility limits

7-7. Effect of reduced infiltration through use of a better cover 7-7

7-8. Effect of maintaining institutional control over part of the INEEL $7-8$

7-9. Areas to be retained and the present value of associated costs 7-10 


\section{ACRONYMS}

AEC Atomic Energy Commission

ALARA as low as reasonably achievable

ANL-W Argonne National Laboratory-West

ANSI American National Standards Institute

ATR Advanced Test Reactor

BAT best available technology

BORAX Boiling Water Reactor Experiment

BRA baseline risk assessment

CA Composite Analysis

CEDE committed effective dose equivalent

CERCLA Comprehensive Environmental Response, Compensation, and Liability Act

CFA Central Facility Area

CIDRA contaminant inventory database for risk assessment

CLP contract laboratory procedure

COPC contaminant of potential concern

DCF dose conversion factor

DOE Department of Energy

DQO data quality objective

EBR Experimental Breeder Reactor

EPA Environmental Protection Agency

ER Environmental Restoration

ERD Environmental Restoration Department

FSP field sampling plan

ICPP Idaho Chemical Processing Plant 
INEEL Idaho National Engineering and Environmental Laboratory

IRA interim risk assessment

IWTS INEEL Waste Tracking System

LLW low-level radioactive waste

LMITCO Lockheed Martin Idaho Technologies Company

LSIT large-scale infiltration test

MCL maximum contaminant level

NESHAP National Emission Standards for radionuclides other than Radon from DOE Facilities

NRF Naval Reactors Facility

PA performance assessment

PARCC precision, accuracy, representativeness, completeness, and comparability

PBF Power Burst Facility

PDD Program Description Document

PRD Program Requirements Document

QAPjP quality assurance project plan

RI/FS remedial investigation/feasibility study

RRWAC reusable property, recyclable materials, and waste acceptance criteria

RWMC Radioactive Waste Management Complex

RWMIS Radioactive Waste Management Information System

SAP sampling and analysis plan

SDA Subsurface Disposal Area

SMC Specific Manufacturing Capability

SRPA Snake River Plain Aquifer

TAN Test Area North

TCLP toxicity characteristic leaching procedure 

TRA Test Reactor Area
TRU transuranic
TSA Transuranic Storage Area
WAG waste area group
WERF Waste Experimental Reduction Facility
WIPP Waste Isolation Pilot Plant 


\section{INTRODUCTION}

The U.S. Department of Energy (DOE) requires a Composite Analysis (CA), in addition to either a Performance Assessment (PA) pursuant to DOE Order 5820.2A or risk assessments pursuant to the Comprehensive Environmental Response, Compensation, and Liability Act (CERCLA), for each active and planned low-level radioactive waste (LLW) disposal facility. The CA is a conservative assessment of the cumulative impacts from active and planned LLW disposal facilities, and all other sources of radioactive contamination that could interact with the LLW disposal facility to affect the dose to future members of the public. The projected total dose to a hypothetical future member of the public from these sources is compared with the DOE primary dose limit of $100 \mathrm{mrem} / \mathrm{yr}$ and with the $30 \mathrm{mrem} / \mathrm{yr}$ dose constraint. If the calculated dose exceeds the 100 mrem primary annual dose limit, an options analysis will be conducted to identify alternatives for reducing future doses to tolerable levels. If the calculated dose exceeds the 30 mrem annual dose constraint, an options analysis will be prepared to consider the actions that could be taken to reduce the calculated dose and to consider the costs of those actions. The CA process, including an Options Analysis and recommendations for further action will support the DOE decision-making process to ensure that continuing LLW disposal will not compromise future radiological protection of the public.

The operating disposal area for LLW at the Idaho National Engineering and Environmental Laboratory (NEEL) is a shallow land disposal facility located at the Radioactive Waste Management Complex (RWMC). The LLW subsurface disposal facility is a large contiguous pit comprising pits 17 through 20 and vertical vaults. Vaults receive waste that requires remote handling for radiation protection. A PA of the active disposal facility was performed by Maheras et al. (1994 and 1997). The PA estimated potential annual radiological doses resulting from the disposal of LLW during the period 1984 through 2020 and the results indicate performance compliance in the $1,000 \mathrm{yr}$ period specified by DOE with a reasonable assurance that public health and safety will be protected.

The RWMC PA was conditionally approved on August 30, 1996 and final acceptance is contingent upon the completion and acceptance of the Composite Analysis. The RWMC CA follows Guidance for $a$ Composite Analysis of the Impact of Interacting Source Terms on the Radiological Protection of the Public from Department of Energy Low-Level Waste Disposal Facilities (DOE, 1996). The entire historical and projected subsurface radiological source term disposed in the vicinity of the operating LLW disposal area as well as additional sources at the INEEL which could affect the radiological dose received by a hypothetical future member of the public are evaluated in the CA. Sources of potential radiation doses beyond the RWMC are evaluated for any contribution due to interacting source terms. The potential dose from gas-phase radionuclides in the air pathway is negligible. The CA presents an analysis of the radiological dose from exposure to contaminated groundwater for all-pathways (consumption of contaminated drinking water, contaminated produce, and contaminated meat and dairy products) for the estimated final subsurface source term at the RWMC.

Included in the RWMC CA report are a discussion of: (1) the RWMC facility and its past, present, and future operations, and its location with respect to other radiological sources on the INEEL, (2) quality of available data, (3) method of source term development, (4) composite performance analysis, (5) sensitivity and uncertainty analysis, (6) interpretation of results, and (7) options analysis. 


\subsection{RWMC Facility Description}

The RWMC contains the historical subsurface disposal area as well as the operating LLW subsurface disposal area for solid radioactive wastes at the INEEL. The RWMC is located in the southwestern portion of the INEEL site (Figure 1-1). The mission of the RWMC is to manage, in a safe and environmentally sound manner, the disposal of low-level radioactive waste and the storage of transuranic (TRU) radioactive waste (transuranic activity greater than $100 \mathrm{nCi} / \mathrm{g}$ ), along with the development of technologies that will serve the waste management needs of present and planned facilities at the INEEL. About $2265 \mathrm{~m}^{3}\left(80,000 \mathrm{ft}^{3}\right)$ of low-level radioactive waste are disposed at the facility each year.

The RWMC is divided into four major areas: Administrative Area, Operations Zone, Subsurface Disposal Area (SDA), and Transuranic Area (TSA) (Figure 1-2). The Administrative Area, locatied in the northeast section of the facility, consists of buildings used for office space and other activities that support operations. The Operations Zone, a 4-ha (10-acre) area located west of the Administrative Area, consists of buildings and storage sheds used for operations and other activities that support the RWMC. The SDA, a 39-ha (97-acre) area located in the western section of the facility, is dedicated to permanent shallow-land disposal of solid, low-level radioactive waste. The SDA is surrounded by a security fence and contains pits, trenches, and vaults for underground waste disposal. The TSA, a 23.5-ha (58-acre) area located in the southern section of the facility, is dedicated to the temporary storage of contact- and remote-handled solid transuranic wastes. Transuranic waste generated by national defense programs was disposed in the SDA from 1954 to 1970 and placed in storage from 1970 to the present. At the facility's Stored Waste Examination Pilot Plant, some of the transuranic waste is being vented, examined, and certified for eventual disposal at a permanent national repository, such as the Waste Isolation Pilot Plant (WIPP) in New Mexico. Nondestructive examination techniques are used to verify that transuranic waste meets the acceptance criteria for WIPP. Certified containers are stored in the Waste Storage Facility until shipment to WIPP for permanent storage.

Mixed hazardous waste materials were disposed of at the SDA from 1952 until late 1983. From 1984 to present only LLW has been disposed to the SDA. Trenches, pits, and soil vault rows that were open before 1984 could potentially contain mixed waste. In terms of disposal locations, this includes waste buried in trenches 1 through 58, soil vault rows 12 through 13 , and pits 1 through 16 . The active LLW disposal area consists of pits 17 through 20, and soil vault rows 14 through 20 representing an area approximately $1.6 \mathrm{ha}$ (4 acres) in size within the 39-ha (97-acre) SDA. An array of vertical concrete vaults for disposal of remote handled LLW is constructed within pit 20.

\subsubsection{Past Disposal Practices}

In A History of the Radioactive Waste Management Complex at the Idaho National Engineering Laboratory (EG\&G 1985), past operations were discussed in terms of four time intervals: early disposal (1952 to 1959), interim burial ground (1960 to 1963), the mid-to-late 1960 s (1964 to 1969), and 1970 to 1985. The intervals were defined on the basis of disposal practices of the day and waste that was received during the period. The information that follows was taken from that document.

1.1.1.1 Disposals from 1952 to 1959. The RWMC was established in 1952 and was managed and operated by the Atomic Energy Commission (AEC) Site Survey Branch. The first trench was opened for the disposal of solid waste in July of 1952 . The RWMC acid pit, located outside of the original burial 


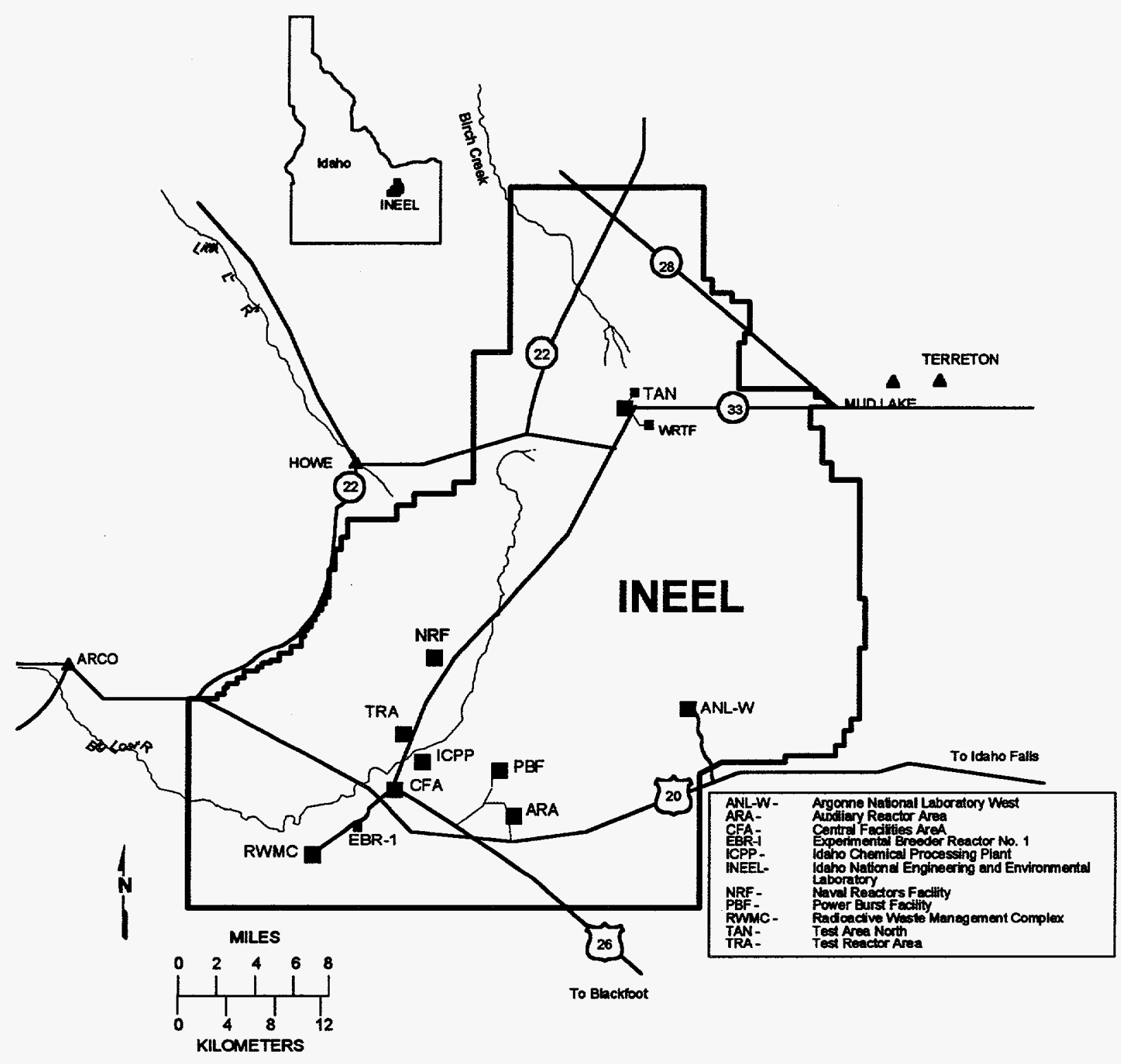

Figure 1-1. Location of the RWMC at the INEEL. 


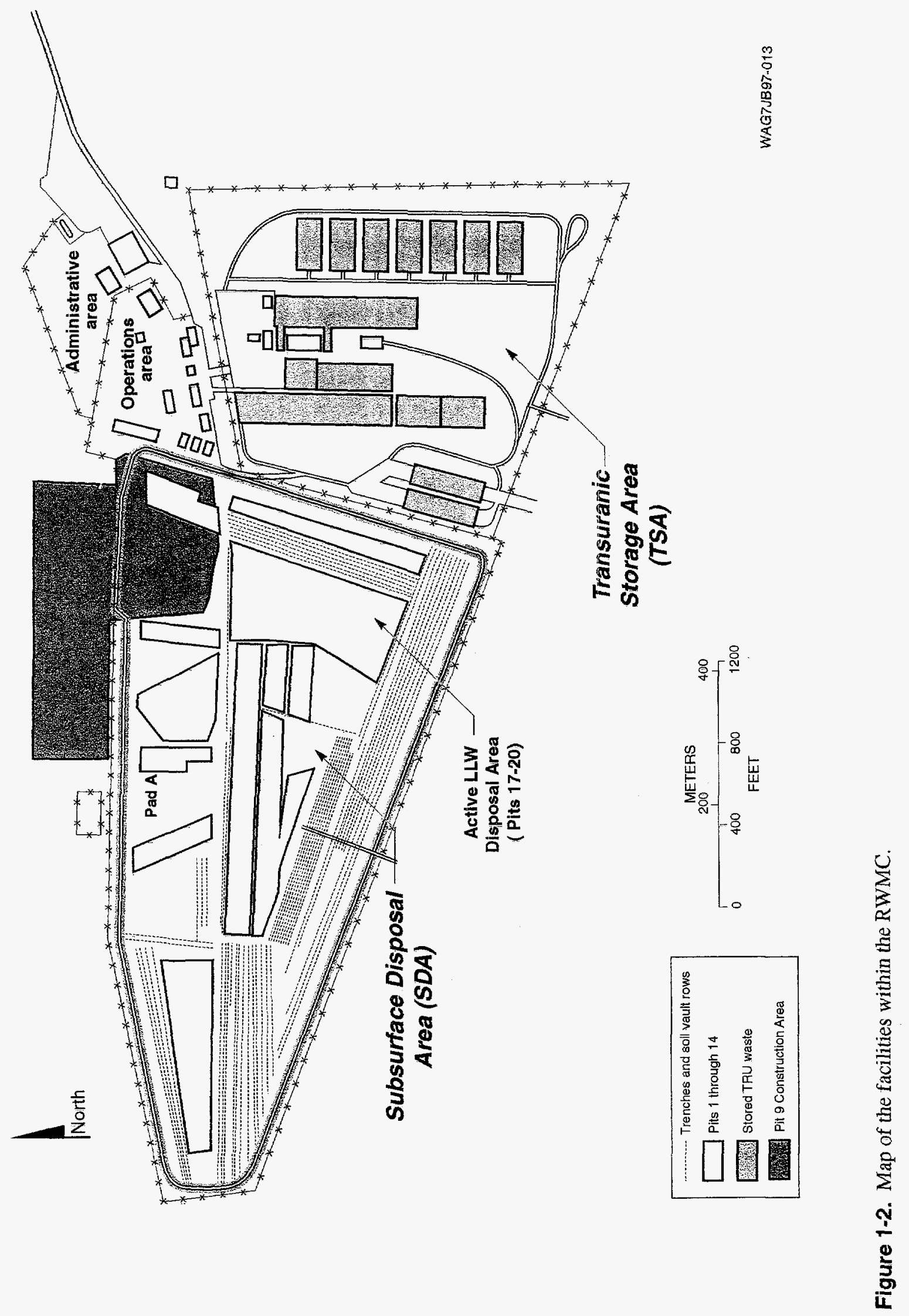


area, began receiving waste in 1954. Between 1952 and 1957, Trenches 1 through 10 were excavated to

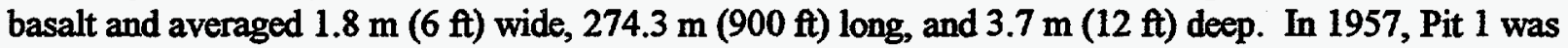
excavated for the disposal of large, bulky items. With the excavation of Pit 1, space in the original burial ground was nearly consumed; therefore, the facility was expanded in 1958 to the current SDA size of 39 ha (97 acres). The acid pit, no longer outside the disposal area, was incorporated within the SDA boundary.

Disposal practices during this time were dependent on the classification of the waste as either routine or nonroutine. Routine solid waste was identified by health physics personnel based on the daily occupational exposure limits at the time. Typically consisting of paper, laboratory glassware, filters, metal pipe fittings, and other items contaminated by mixed fission products during testing operations, routine solid waste was packaged in cardboard boxes. The boxes were taped shut and collected in dumpsters that eventually were emptied into the trenches in the burial ground. Nonroutine waste, defined as waste that could cause excess personnel exposure, was either placed in wooden boxes or in garbage cans. Special transport containers and vehicles were used to haul the waste to the disposal site. Up until 1957, the radiation level was not limited for any disposal, and items registering up to $12,000 \mathrm{R} / \mathrm{hr}$ were buried. Both nonroutine and routine waste was covered with soil, but according to different schedules. Nonroutine waste was covered immediately whereas routine waste boxes may have been left exposed until the end of an operating week. Because completion of a "waste disposal form" was not a requirement until 1959, early disposal records are sketchy. In 1959 procedures were standardized with the establishment of formal definitions of routine and nonroutine waste. The new procedure also required the completion of a standardized waste disposal form.

During the early waste disposal period, the RWMC also accepted waste shipments for permanent disposal from the Rocky Flats Plant under authorization of the AEC. TRU waste from Rocky Flats, packaged in drums or wooden crates, was stacked horizontally in pits and trenches along with the INEEL mixed fission product waste from 1954 to 1957. Therefore, most of the pits and trenches in the original burial ground contain INEEL waste interspersed with TRU waste from Rocky Flats. The records for the Rocky Flats disposals did not accompany the shipments. Instead, an annual summary of disposals provided total radionuclide content and waste volume.

Originally, trench locations were recorded by observation against metal tags placed at regular intervals along the barbed-wire enclosure that surrounded the burial ground. In the late 1950s, this procedure was discontinued, and concrete survey monuments were placed at the ends of the centerline of each trench and at the corners of each pit. A brass plate stamped with the trench or pit number and the dates the trench or pit was opened and closed, and a direction arrow were affixed to each monument. The older disposal sites were retrofitted with monuments, but the accuracy of the locations is somewhat uncertain.

1.1.1.2 Disposals from 1960 to 1963. The AEC determined that land disposal was preferable to offshore ocean disposal of solid radioactive waste. However, a commercially operated land disposal site was not available to private industries licensed by the AEC. Therefore, the AEC created an Interim Burial Ground Program for disposal of solid radioactive waste generated by AEC licensees while commercial sites were selected and established. Two facilities for interim disposal were selected and the RWMC became one of the two. From 1960 until commercial burial sites became available in 1963, the RWMC accepted approved shipments from off-Site generators in addition to the Rocky Flats and INEEL waste for disposal at the burial ground. Waste shipments from Rocky Flats continued after the commercial sites opened because of security concerns. 
During this period, several changes occurred in burial ground operations. First, the AEC delegated authority to manage and operate the burial ground to the INEEL operating contractor. Tasks managed under this authority included health physics surveillance and arrangements for nonstandard disposals. The contractor refined and formalized standard practices for disposal operations and implemented a system of careful record keeping. Another change in disposal practices regarded the physical burial of TRU waste from Rocky Flats. Beginning in November 1963 and continuing until 1969, drums from Rocky Flats were dumped into pits rather than stacked to reduce labor costs and personnel exposures. Environmental monitoring systems were improved to incorporate film badges around the perimeter of the burial ground.

During the time from 1960 to 1963 when the Interim Burial Ground Program was active, Trenches 16 through 25 and Pits 2 through 5 were open for disposal. These excavations received some mixture of stacked or dumped Rocky Flats TRU waste, and off-Site waste.

1.1.1.3 Disposals from 1964 to 1969. By the mid-1960s, concern about the environmental impacts of waste disposal significantly influenced waste management. Disposal practices, monitoring systems, and the adequacy of facilities were subjected to critical scrutiny, resulting in the passage of environmental legislation designed to protect the environment. In Idaho, the particular concern was then, as now, about maintenance of water quality in the Snake River Plain Aquifer (SRPA). Numerous studies were conducted by various agencies that concluded previous burial of radioactive waste did not generate off-Site health or safety problems. However, several improvements were recommended to monitor and mitigate potential impacts from continued waste burial.

Modifications to procedures for permanent interment included: (1) increasing the minimum trench depth from 0.9 to $1.5 \mathrm{~m}$ ( 2 to $5 \mathrm{ft}$ ), (2) lining the bottoms of excavations with at least $0.6 \mathrm{~m}(2 \mathrm{ft})$ of soil underburden, (3) compacting the waste by dropping a heavy steel plate on the waste in trenches, and (4)

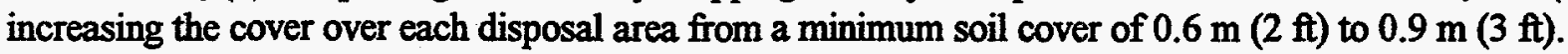
These modifications were implemented between 1964 and 1970. In addition, TRU disposal, especially plutonium-contaminated waste, was discontinued in 1969. Instead of burying TRU waste, the waste containers were stacked aboveground.

The environmental monitoring program was revised during this period. The 35 film badges around the perimeter of the burial ground were replaced with 18 thermoluminescent dosimeters. Water sarnples also were collected and analyzed from subsurface monitoring holes, and field investigations to assess leaching were conducted. Threats to the aquifer were not identified.

1.1.1.4 Disposals from 1970 to 1985. The greatest departure from previous disposal practices during this period was the implementation of the 1970 AEC Policy Statement Regarding Solid Waste Burial (EG\&G 1985; AEC 1970). The policy required segregated and retrievable storage of all solid waste contaminated with long-lived TRU in concentrations of greater than $10 \mathrm{nCi} / \mathrm{g}$. The AEC also committed to removing buried and stored TRU from the RWMC. The new policy initiated several changes in waste disposal practices within the SDA and was the genesis of the TSA for the above-ground storage of TRU waste until a permanent repository for such waste becomes available. Originally, TRU waste was defined as all waste contaminated with TRU radionuclides in concentrations greater than $10 \mathrm{nCi} / \mathrm{g}$. In 198.2, the definition of TRU was redefined as materials with concentrations of greater than $100 \mathrm{nCi} / \mathrm{g}$ at the end of institutional control containing alpha-emitting radionuclides of atomic number greater than 92 and balflives longer than 20 years.

A pad was constructed within the SDA in an area found unsuitable for subsurface disposal clue to the presence of shallow surficial sediments. Originally called the Engineered Waste Storage Area, this pad 
was later called the Transuranic Disposal Area and is now commonly referred to as Pad A. Pad A waste contains TRU alpha-emitting radioisotopes with concentrations of less than $10 \mathrm{nCi} / \mathrm{g}$ and exposure rates less than $200 \mathrm{mR} / \mathrm{hr}$ at the container surface. Pad A waste was not officially categorized as TRU, but interim disposal techniques were implemented in the event of the desire or requirement of retrieval in the future. Boxes were stacked around the periphery of $\mathrm{Pad} A$, and drums were stacked horizontally in staggered layers and covered with soil. Disposal operations were conducted on Pad A from 1972 to 1978. The pad and waste were covered with a final soil layer with a minimum 0.9-m (3-ft) thickness, contoured to a maximum 1:3 slope, and seeded with grass.

Other modifications including compaction, packaging criteria, and enlarging pit volumes were made to SDA disposal practices during 1970 to 1985 because of concern about space availability. The Naval Reactors Facility (NRF) began compacting its disposals beginning in 1971. By 1974 the practice of compacting waste developed by NRF was implemented at the RWMC. Generators of waste at the INEEL, except NRF, began sorting their own waste and shipping non-TRU compactible waste to the RWMC in plastic bags to expedite compaction operations. The volumes of pits were expanded by using heavy equipment to remove fractured basalt from the base of the excavations. Beginning with Pit 17 in 1980 , explosive fracturing was used to deepen pit excavations. A soil underburden of at least $0.6 \mathrm{~m}(2 \mathrm{ft})$ thick was added to cover the basalt before waste was interred, and a final layer of compacted soil at least $0.9 \mathrm{~m}$ ( $3 \mathrm{ft}$ ) thick covered the buried waste. In 1985, the practice of incorporating a geotextile liner into the underburden was implemented. Packaging criteria were modified in 1978 to facilitate close-packed array stacking within the pits. In combination, the above practices greatly expanded the useable space within the SDA and significantly extended the operational lifetime of the facility.

Additional changes to disposal practices were implemented during the 15-yr period to minimize personnel exposures to radiation emanating from the waste. Beginning in 1977, areas not suited for pits were reserved for soil vault rows. Soil vaults, consisting of cylindrical vertical shafts with diameters ranging from 0.4 to $2 \mathrm{~m}(1.3$ to $6.5 \mathrm{ft})$ and averaging about $3.6 \mathrm{~m}(12 \mathrm{ft})$ deep, were drilled in rows, and vaults within any given row were at least $0.6 \mathrm{~m}(2 \mathrm{ft})$ apart. At least $0.6 \mathrm{~m}(2 \mathrm{ft})$ of soil was placed in the hole if basalt was penetrated during drilling. The soil vaults were designed for the disposal of highradiation waste, defined as materials producing a beta-gamma exposure rate greater than $500 \mathrm{mR} / \mathrm{hr}$ at a

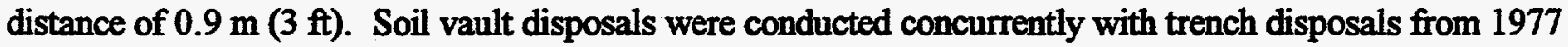
to 1981 . Trenches also received high-radiation waste until trench disposal was discontinued in 1981 and the unfilled trench area was redesigned for soil vaults. General disposal practices were the same for pits, trenches, and soil vaults. For example, compacted waste was baled; larger, bulky items were wrapped in plastic; and smaller noncompactible waste was contained in wooden boxes covered with fire retardent paint. Waste was placed into the excavations by free-air transfer or in shielded casks, depending on the exposure rate measured on the outside of the waste container. The three types of waste were buried in separate areas within a given excavation. To expedite natural drainage, a final soil cover at least $0.9 \mathrm{~m}$ ( 3 ft) thick was crowned and compacted over each excavation as it became full.

\subsubsection{Disposal Practices Since 1985}

Presently Pits 17, 18, 19, and 20 and Soil Vault Rows 14 through 20 are the major burial areas open in the SDA to receive LLW. About $2,265 \mathrm{~m}^{3}\left(80,000 \mathrm{ft}^{3}\right)$ of LLW are disposed to the facility each year.

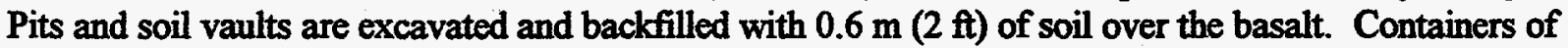
waste are stacked in the pit or soil vault. An earth cover is applied to provide a minimum cover of $0.9 \mathrm{~m} \mathrm{(3}$ $\mathrm{ft}$ ) over all waste during the operational period. Additional earth covering may be applied during operations if the radiation level of the covered waste is greater than $1 \mathrm{mrem} / \mathrm{h}$ at $0.9 \mathrm{~m}(3 \mathrm{ft})$ above the ground. 
LLW generated at the INEEL primarily consists of contaminated or potentially-contaminated protective clothing, paper, rags, packing material, glassware, tubing, and other general-use items. Also included is contaminated equipment (such as gloveboxes and ventilation ducts) and process waste (such as filter cartridges and sludges). These materials are either surface contaminated with radionuclides or are activated from nuclear reactions. Most of the radioactivity in the LLW at the time of receipt stems from short-lived radionuclides. Most of this waste has an external exposure rate of $<500 \mathrm{mR} / \mathrm{h}$ at $0.9 \mathrm{~m} \mathrm{(3 \textrm {ft } )}$ from the container surface.

LLW disposed in the SDA must meet the requirements of the INEEL Reusable Property, Recyclable Materials, and Waste Acceptance Criteria (RRWAC). Should new LLW streams develop and have characteristics different than those allowed in the RRWAC, the waste stream is not accepted for disposal at the RWMC until an analysis ensures the limitations of the RRWAC and RWMC are not exceeded. The four categories of LLW handled at the INEEL are nonprocessible (direct disposal) waste, compactible waste, incinerable waste, and sizable waste.

Nonprocessible waste is LLW that currently cannot be processed at the INEEL Waste Experimental Reduction Facility (WERF) due to radiation levels, size, or composition. Nonprocessible waste is directly disposed at the SDA and comes to the RWMC in containers such as wooden boxes, metal bins, and 55-gal drums. The RRWAC prohibits the disposal of free liquids, hazardous materials, and pyrophorics and require physical and chemical waste characterization. Void space minimization is required by the RRWAC.

Compactible waste is LLW that cannot be incinerated at WERF but can be compacted. Compactible waste generally contains halogens or sulfur and some rubber materials, with a radiation level $<200 \mathrm{mR} / \mathrm{hr}$ at the surface. Compactible waste is sent to WERF where it can be compacted into $1.2 \times 1.2$ $x 1.8-\mathrm{m}(4 \times 4 \times 6-\mathrm{ft})$ metal boxes. Compaction achieves a volume reduction ratio of about 5:1. After compaction, the waste is shipped to the RWMC for disposal.

Incinerable waste consists of rags, plastics, wood, and other combustible material with a radiation level less than $20 \mathrm{mR} / \mathrm{hr}$ at contact. Most incinerable waste is packaged in cardboard boxes and shipped to WERF where it may be burned in the WERF incinerator. A volume reduction ratio of 50:1 to 300:1 can be obtained depending on the type of material incinerated. The resulting fly ash mixed waste is treated by solidification with cement in 71-gal drums to stabilize the chemically hazardous levels of lead and cadmium. To assess the effectiveness of treatment and approval for shipping to the RWMC, the treated fly ash is sent for toxicity characterization leaching procedure (TCLP) testing. When the stabilized fly ash passes the TCLP it is shipped to the RWMC for disposal.

WERF sizing waste is defined as metal (aluminum, stainless and carbon steel, copper, and others) with wall-thickness too great for compaction with the WERF 200-ton compactor, having radiation levels $<100 \mathrm{mR} / \mathrm{hr}$ at contact, and free of toxic and hazardous material. Metallic waste for sizing is shipped to WERF in bins. The bulk metal shipments are then reduced in size to where a volume reduction of about $4: 1$ is achieved. The sized waste is then packaged and shipped to the RWMC for disposal.

Disposal of contact-handled LLW since 1984 has averaged approximately $2,000 \mathrm{~m}^{3} / \mathrm{yr}(70,620$ $\left.\mathrm{ft}^{3} / \mathrm{yr}\right)$. In addition, an average of $73 \mathrm{~m}^{3} / \mathrm{yr}\left(2,577 \mathrm{ft}^{3} / \mathrm{yr}\right)$ of remote-handled LLW has been received from waste generators; containers of this waste have been disposed of at the RWMC in waste disposal pits or in soil vaults. 
1.1.2.1 Low-Level Radioactive Waste Disposal Pits. Currently a single large excavated area is used for open pit disposal of LLW at the SDA. The excavation is approximately $182.9 \mathrm{~m} \mathrm{(660} \mathrm{ft)} \mathrm{long,}$ $91.4 \mathrm{~m} \mathrm{(300} \mathrm{ft)} \mathrm{wide,} \mathrm{and} 9.1 \mathrm{~m}(30 \mathrm{ft})$ deep and is designated as four pits consecutively numbered 17 through 20 (Figure 1-2). A $0.7 \mathrm{~m}$ (2ft) cover of sediment and a thin layer of gravel is placed over the floor of the excavation where basalt was exposed during excavation. Geofabric has been placed beneath the thin gravel cover in some areas of the excavation floor to provide a stable surface for vehicles and equipment.

Waste disposed in the pits is packaged in barrels, wooden boxes, and metal bins. The greatest volume of waste is placed in wooden boxes. For disposal, the waste is segregated by the type of packaging and then placed in the pits as free-standing stacks. The wooden boxes are stacked in the central portion of the excavation, metal bins and materials with odd size or shape are placed on the western side, and metal bins, drums, and cargo containers are disposed on the eastern side of the excavation. Waste is closely

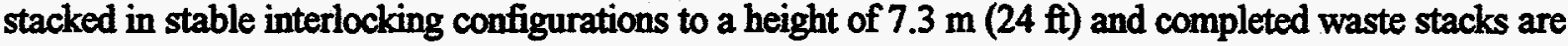
covered with approximately $1.2 \mathrm{~m}(4 \mathrm{ft})$ of sediment.

1.1.2.2 Low-Level Radioactive Waste Disposal SoillConcrete Vaults. Soil vaults are vertical cylindrical borings drilled into the subsurface at the SDA and are used to dispose of remote handled LLW which has sufficiently high radiation levels $(>500 \mathrm{mR} / \mathrm{hr})$. The diameter of soil vaults constructed in the SDA ranges from $0.4 \mathrm{~m}$ to $2.0 \mathrm{~m}$ ( $1.3 \mathrm{ft}$ to $6.5 \mathrm{ft}$ ) and soil vaults average $3.7 \mathrm{~m}(12 \mathrm{ft})$ in depth, with a minimum depth of $2.0 \mathrm{~m}(6.6 \mathrm{ft})$. When a soil vault bottoms in basalt, $0.6 \mathrm{~m}(2 \mathrm{ft})$ of soil is placed in the bottom of the vault. The soil vaults are held open until they are filled with LLW. Once a vault is filled it is covered with soil to a minimum thickness of $0.9 \mathrm{~m}(3 \mathrm{ft})$. Each vault is separated from the previous vault by a minimum distance of $0.6 \mathrm{~m}(2 \mathrm{ft})$. The vaults are constructed in rows along predetermined center lines. There are currently 20 soil vault rows at the SDA. Soil vault rows 1 through 13 are inactive disposal sites and are being investigated under the CERCLA program. Soil vault rows 14 through 20 are considered active LLW disposal sites interspersed between existing trenches of the CERCLA portion of the SDA and will be closed under the CERCLA program.

In the southwest corner of the active LLW disposal pit area is a $17.7 \mathrm{~m}(58 \mathrm{ft})$ by $8.2 \mathrm{~m}(27 \mathrm{ft})$ area which contains enhanced concrete lined vaults for the disposal of remote handled LLW. The concrete vaults are specifically used to dispose of waste generated by the NRF. All remote handled LLW generated by other INEEL facilities is disposed in soil vaults. The vault array is oriented length-wise to the north, with the east west sides of the array being the long sides. The concrete vault array is $7.6 \mathrm{~m}(25 \mathrm{ft})$ in depth and extends from the land surface of the top of the pit area (msl elevation $1527.0 \mathrm{~m}$ or $5010 \mathrm{ft}$ ) to the base of the pit (msl elevation of $1519.4 \mathrm{~m}$ or $4985 \mathrm{ft}$ ). Approximately $1.5 \mathrm{~m}(5 \mathrm{ft})$ of backfill is beneath the concrete vault array.

Waste disposal in the concrete vault array is similar to the soil vault disposal. The concrete vaults

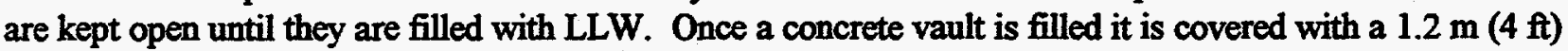
thick reinforced concrete plug. To inhibit moisture infiltration into the vaults, the seams between adjacent plug caps of filled vaults are sealed with acrylic caulk at the surface of the vault array. Presently, there are approximately $\mathbf{5 0}$ concrete vaults in pit 20 but only about half of them are filled at this time.

\subsubsection{Future Disposal}

LLW waste disposal is expected to continue through the year 2020. Similar disposal practices are assumed to be used. 


\subsection{Potential INEEL Sources Which May Impact the Performance of the RWMC LLW Facility}

The INEEL encompasses $2,305 \mathrm{~km}^{2}\left(892 \mathrm{mi}^{2}\right)$ with nine major facilities scattered across the site: Test Area North (TAN), NRF, Test Reactor Area (TRA), Idaho Chemical Processing Plant (ICPP), Central Facility Area (CFA), Power Burst Facility (PBF), Argonne National Laboratory-West (ANL-W), Experimental Breeder Reactor I (EBR-I), and RWMC (see Figure 1-1). The distance between the RWMC and other major INEEL facilities ranges from just a few kilometers (EBR-1) to over $50 \mathrm{~km}(31 \mathrm{mi})$ to the north (TAN) and over $30 \mathrm{~km}$ (19 mi) to the east (ANL-W).

Under the CERCLA program the INEEL is divided into Waste Area Groups (WAGs) to facilitate environmental remediation efforts. WAGs 1 through 9 generally correspond to the INEEL operational facilities, while WAG 10 corresponds to overall concerns associated with the SRPA and those surface and subsurface areas not included in the bounds of the facility-specific WAGs.

TAN (WAG 1) is located at the north end of the INEEL, about $55 \mathrm{~km}$ (34 mi) northeast of the RWMC (WAG 7). TAN was established in the 1950s by the U.S. Air Force and Atomic Energy Commission Aircraft Nuclear Propulsion Program to support nuclear-powered aircraft research. Upon termination of this research, the area's facilities were converted to support a variety of other DOE research projects. Environmental sites under investigation at TAN include an injection well, pits, rubble disposal sites, tanks, wastewater disposal ponds, burn pits, a sewage lagoon, and historic spill sites.

TRA (WAG 2) is located in the southwest portion of the INEEL, $19 \mathrm{~km}$ (12 mi) northeast of the RWMC. The major mission of TRA is to conduct scientific and engineering experiments in behalf of DOE and to support various nuclear and nonnuclear programs. TRA was established in the early 1950 s with the development of the Materials Test Reactor. Two other major reactors: the Engineering Test Reactor and the Advanced Test Reactor were built soon after. The Materials Test Reactor was shut down in 1970, and the building is now used for offices, storage, and test areas in support of activities at ICPP. The Engineering Test Reactor has been inactive since January 1982. The major program at the area now is the Advanced Test Reactor. Sites being investigated at TRA include pits, tanks, rubble piles, ponds, cooling towers, wells, french drains, and spills. A comprehensive Remedial Investigation/Feasibility Study (RI/FS) for TRA has been evaluated under the CERCLA program and more detailed information about this facility may be found in Burns et al. (1997).

ICPP (WAG 3) is located about $16 \mathrm{~km}(10 \mathrm{mi})$ northeast of the RWMC. The mission of the plant is to receive and store spent nuclear fuels and radioactive wastes, treat and convert wastes, and develop new technologies for waste and waste management for the DOE. Before April 1992, this mission also included nuclear fuel reprocessing. However, reprocessing work was phased out, and consequently, facilities once dedicated to reprocessing work will be converted to a safe and stable shutdown condition while awaiting reuse or decontamination and decommissioning. Sites being investigated at ICPP include facilities associated with wastewater disposal systems such as sumps, ponds, and an injection well, spills, and tank farm storage systems.

CFA (WAG 4) is located about $11 \mathrm{~km}(7 \mathrm{mi})$ northeast of the RWMC and is the main service and support center for the programs located at the INEEL's other primary facility areas. Eighty percent of the activity at CFA consists of INEEL-wide programmatic support such as transportation, maintenance, capital construction, environmental and radiological monitoring, security, fire protection, warehouses, calibration laboratories, and a cafeteria. A small amount of research and development work is also 
conducted. Work on radioactive and hazardous materials is restricted in and around CFA. Sites under investigation at CFA include historical spills, tanks, landfills, ponds, leach fields, and leach pits.

PBF (WAG 5) is located in the south-central portion of the INEEL, about $26 \mathrm{~km}$ (16 mi) northeast of the RWMC. PBF was established in the 1950s to test the operational behavior of reactors and to study the safety of light-water-moderated, enriched fuel systems. Now the mission of PBF is to become a regional and national center for hazardous waste reduction and mixed waste treatment, research, and development. Sites being investigated at PBF include evaporation ponds, percolation ponds, leach fields, pits, and dry wells. In conjunction with WAG 5 is the Auxiliary Reactor Area (ARA). ARA consisted of four separate groupings of buildings in which various activities have occurred including the operation of test reactors. All of the ARA reactors have been removed from the facility and have undergone partial or complete decontamination and decommissioning.

EBR-I (WAG 6) is located in the southwestern portion of the INEEL site, about $3 \mathrm{~km}$ (2 mi) northeast of the RWMC. EBR-I was the first reactor built on the site and the first reactor in the world to generate electricity. It began operating on December 20, 1951. This reactor provided the first proof that nuclear fuel breeding (creating more fuel than is used) was feasible. It is no longer operational, however it has become a National Historic Landmark. Also within WAG 6 are the remains of the Boiling Water reactor Experiment (BORAX) facilities. The BORAX-I reactor was a small experimental reactor used in the summer months for 1953 and 1954 for testing boiling water reactor technology. BORAX-I was designed to investigate the ability of the reactor to protect itself against sudden, artificially-induced increases in reactivity. During the last test, the reactor was intentionally destroyed to determine its inherent safety under extreme conditions. Subsequent BORAX experiments, BORAX-II through V, were conducted

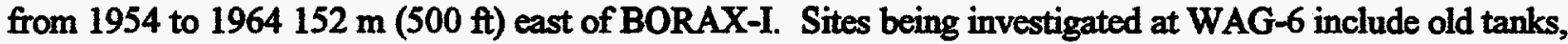
a small spill area, and several liquid and solid waste disposal locations.

RWMC (WAG 7), was established in 1952 and is a controlled area for the disposal of solid radioactive waste generated at the INEEL. The primary site being investigated under the CERCLA agreement is the SDA within the RWMC which includes pits, trenches, and vaults where radioactive and organic wastes were placed, with the exception of the active low-level radioactive waste storage area (Pits 17-20). The TSA within the RWMC has been used since the early 1970 s for retrievable storage of transuranic waste on earthen-covered pads and in facilities awaiting final shipment to WIPP. The Stored Waste Examination Pilot Plant is also located at the RWMC and is used for certifying waste destined for shipment to WIPP.

NRF (WAG 8), a part of the Bettis Atomic Power Laboratory, was established in the early 1950s to support development of naval nuclear propulsion. The facility is $27 \mathrm{~km}(17 \mathrm{mi})$ northeast of the RWMC and is operated by Westinghouse Electric Corporation under the direct supervision of the DOE's Office of Naval Reactors. The facility supports the Naval Nuclear Propulsion Program by carrying out assigned testing, examination, and processing activities. Sites under investigation at NRF include landfills, old spills, wastewater disposal systems, such as ponds, ditches, basins, drains, and drain fields, and storage areas.

ANL-W (WAG 9) is located in the southeastern portion of the INEEL site, about $39 \mathrm{~km}$ (24 mi) northeast of the RWMC. ANL-W is the prime testing center in the U.S. for advanced reactor systems research. Research centered on the Experimental Breeder Reactor II that operated from 1964 to 1994. Along with the reactor's research contributions, it produced electrical power with an electrical output of 19.5 megawatts of electricity. The reactor is currently being defueled for decommissioning. Sites being investigated at ANL-W include tanks and wastewater handling and disposal systems. 


\section{DATA QUALITY OBJECTIVES}

Data quality objectives (DQOs) for the Composite Analysis are established by identifying the types of decisions that will be made and identifying the data uses and needs. The primary decision types addressed by the Composite Analysis are planning decisions. The Composite Analysis is intended to be a conservative estimate of the cumulative impacts of the active LLW disposal facility and other sources at INEEL that may interact to contribute to the total dose to a hypothetical future member of the public. The intent of the Composite Analysis is to provide DOE with ample information to make reasonable management decisions regarding the total LLW disposal system and resource expenditure. Data used in the Composite Analysis must be of sufficient quality to support justification of assumptions and therefore ensure credibility. The general processes used to ensure data quality in the source term inventory data, computer simulations, and environmental data used in the Composite Analysis are described below.

\subsection{Inventory Data}

Historically the quality of RWMC source term inventory data has periodically been improved as methods of measuring and estimating radionuclide inventories have been refined. Early records do not include individual radionuclides and the radioactivity was estimated not measured. Improved radionuclide identification procedures have resulted in improved estimates of container activity. In addition, data on physical and chemical characteristics are now collected. Waste management records have been computerized and incorporated into the Radioactive Waste Management Information System (RWMIS).

Several efforts have refined the estimates of disposed inventory in the SDA. Plansky and Hoiland (1992) initially improved information regarding radionuclides in LLW buried at the RWMC by reconciliation of RWMIS data with generator information. The study utilized generator review of data captured in RWMIS and subsequent input regarding past processes, disposed wastes, radionuclides, activities, weights, and the existence of other sources of information or disposal records. Discrepancies in disposal data were identified and RWMIS was updated accordingly.

Barnard (1992) performed verification of shipment-specific waste information contained in historical databases with the RWMIS database. Original shipping manifests that accompanied the waste shipments for the years 1961 through 1984 were compared with fields on printouts of the RWMIS database. Inconsistencies were noted, and proposed amendments to the RWMIS database were reviewed and resolved. The RWMIS database was subsequently updated accordingly.

LMITCO Environmental Restoration Department (ERD) data requirements have led to additional refinement of the knowledge of the radionuclide inventory disposed in the SDA. Environmental Restoration (ER) activities have resulted in the development of a Contaminant Inventory Database for Risk Assessment (CIDRA). Development of the CIDRA is documented in LMITCO (1995a) and LMITCO (1995b). The CIDRA was developed using waste generation process knowledge and various supporting information from reports, shipping, databases, and nuclear physics calculations. The CIDRA effort resulted in a best estimate quantity for each known disposed contaminant including lower and upper bounding estimates.

For the CA, refinements to radionuclide inventory estimates were performed to rectify identified data gaps associated with CIDRA. Data gaps were identified and reconciled in key waste streams from ANLW, NRF, TRA, and the Specific Manufacturing Capability (SMC) at TAN for radionuclides critical to the performance of the active LLW disposal pits at the SDA. The waste stream updates will be incorporated into CIDRA. Carboneau (1998) provides a reassessment of neutron activation product radionuclides in EBR-II core non-fuel bearing structural metal hardware disposed from ANL-W. Abbott (1997a,b) and 
Bradley (1998) provide refined estimates of key environmental radionuclides in NRF core structural waste and expended ion exchange resin waste disposed in the SDA. Schnitzler (1995) calculated refined estimates of the radionuclide inventories in ATR beryllium (Be) reflector blocks and outer shim control cylinders. The data of Schnitzler (1995) were extrapolated by Honeycutt (1998) to estimate the inventory of selected radionuclides in the reported Be block disposals from TRA. Sterbentz (1998) has calculated key environmental radionuclide estimates for all core components removed from the Advanced Test Reactor (ATR) core per the Core Internal Change-out schedules, the ATR core component inventory disposed in the RWMC SDA is not determined therefore, the estimate provides a conservative upper limit. Schnitzler (1998) has calculated an estimate of C-14 production in ATR coolant, providing a basis for the determination of Abbott (1998) for estimated C-14 inventory in TRA resin disposal shipments to the SDA.

Current practices for shipping LLW to the RWMC require waste generators to be approved and the waste stream to be authorized to ensure compliance with requirements of RRWAC. Waste streams are characterized to ensure the physical and chemical characteristics and radionuclide content are known and recorded during all stages of the waste management process. The waste characterization and certification process is a controlled process that uses records, statements, reports, and data along with a waste certification statement signed by the waste generator. Waste shipment information is input into The INEEL Waste Tracking system (WTS) which provides for tracking the creation, transportation and disposal of LLW.

\subsection{Computer Simulation Codes}

The Lockheed Martin Idaho Technologies Company (LMITCO), prime contractor for management of the INEEL, Management Control Procedure 550 "Software Management" establishes the companywide uniform standard for the management and maintenance of software. Software quality assurance requirements including verification and validation requirements for software used by LMTCO are found in (a) DOE orders, (b) NQA-1, (c) LMITCO Program Requirements Document (PRD)-101 Quality Assurance Program, (d) LMITCO Program Description Document (PDD)-1 Quality Assurance Program, (e) LMITCO PDD-12 Engineering Design, and (f) other codes and standards, such as those developed by American National Standards Institute and Institute of Electrical and Electronic Engineers.

\subsubsection{Source Term Release Simulation}

The source term release model provides prediction of the release of contaminants into the subsurface. The release model utilized the DUST-MS simulation code (Sullivan 1993) to predict releases from buried waste into the subsurface. DUST-MS is a one-dimensional model and three release mechanisms of surface washoff, diffusion, and dissolution. Container failure time can be specified. DUST-MS was identified during the model selection and validation process (Becker 1997) as the appropriate code for the source term modeling. The release models used in DUST-MS are well documented (Sullivan 1993).

\subsubsection{Transport Simulations}

Transport of released mass in the subsurface was simulated using the TETRAD code (Vinsome and Shook 1993). TETRAD is a petroleum engineering/geothermal numerical simulator that has been adapted for use in environmental studies. TETRAD is a three-dimensional, three-phase transport code which can model flow in either porous or fractured media and is well-suited for simulating multi-phase, multi-component transport. Problem descriptions and comparisons to analytical solutions used to verify TETRAD application to environmental simulations are provided in Shook (1995). Comparison to analytical solutions for applications of TETRAD to petroleum/geothermal problems is given in Vinsome and Shook (1993) and Shook and Faulder (1991). TETRAD results give favorable comparison to results 
from MAGNAS multiphase simulation code and thereby provide a partial benchmarking of TETRAD (Magnuson 1996).

Quality assurance requirements that have been completed for GWSCREEN include documentation of software requirements, theory of operation, and user documentation. Verification and validation test plans (Rood 1993) and a verification and validation report (Smith and Whitaker 1993) have been completed.

\subsubsection{Radiation Physics Simulations}

Radiation physics simulations are used to support source term development. Both MCNP2 and ORIGEN2 have been used to predict radionuclide source quantities. Additionally, MICROSHIELD has been used in source term extrapolation.

A formal verification and validation of ORIGEN2 has not been published by the code developers, Oak Ridge National Laboratory. However, a number of verification activities have been undertaken, including comparison of ORIGEN2 decay heat results with both calculated and experimental values and a comparison of predicted spent fuel compositions with measured values. ORIGEN2 is used widely at DOE facilities and in the commercial nuclear industry, and it is an industry standard for calculations of the production, decay, and ingrowth of radionuclides. MCNP2 is a validated code used extensively in reactor calculations. A comprehensive verification of MICROSHIELD has been performed, and comparisons to both ANSI and European Shielding Information Service benchmark shielding problems have been published.

\subsection{Environmental Data}

DQOs for ER data collection are essentially statements that specify the quality of data required to support decisions during remedial response activities. DQOs are established before data collection and are developed through a process (i. e. DQO development process) which is integrated into project planning. Results of the DQO development process are incorporated into Sampling and Analysis Plans (SAPs), Quality Assurance Project Plans (QAPjPs), and in a general fashion are incorporated into work plans. Guidance provided in Data Quality Objectives for Remedial Response Activities, Development Process (EPA 1987) is typically used in the development of DQOs.

Ideally DQOs should be specified for each data collection activity associated with remedial response activities. Development of DQOs is a three stage process:

- Stage 1 decision types are identified,

- Stage 2 data uses and needs are identified,

- Stage 3 data collection programs are designed.

To delineate decision types it is generally necessary to (a) identify and involve data users, (b) evaluate available information, (c) develop a conceptual model, and (d) specify objectives and decisions. To identify data uses and needs requires (a) identification of data uses, types, quality needs, and quantity needs; (b) evaluation of sampling and analysis options; and (c) review of precision, accuracy, representativeness, completeness, and comparability (PARCC) parameters. 
Data collection programs such as a Field Sampling Plan (FSP) result from the implementation of the first two stages of the DQO process: (1) identification of decision type, and (2) identification of data uses and needs.

Uniformity in data quality for ER data collection is achieved through the use of site-wide quality assurance requirements of the Quality Assurance Project Plan for Waste Area Groups 1, 2, 3, 4, 5, 6, 7, 8, 9 and 10 (Baumer et al., 1995). The site-wide QAPjP establishes minimum standards for the following data collection elements:

- quantitative and qualitative quality assurance objectives;

- sample site selection and sampling procedures;

- analytical procedures and calibration;

- $\quad$ preventive maintenance;

- data reduction, validation and reporting;

- internal quality control checks;

- systems and performance audits/evaluations;

- calculation of data quality indicators;

- corrective action; and

- quality-control reports to management. 


\section{SOURCE TERM DEVELOPMENT}

The sources of radioactive material at the INEEL that may contribute to the potential dose from the active LLW disposal facility at the RWMC are selected in accordance with Guidance for a Composite Analysis of the Impact of Interacting Source Terms on the Radiological Protection of the Public from Department of Energy Low-Level Waste Disposal Facilities (DOE 1996). All major INEEL facilities were considered during the term source screening process: TAN (WAG-1), TRA (WAG-2), ICPP (WAG3), CFA (WAG-4), PBF/ARA (WAG-5), EBR-1/BORAX (WAG-6), RWMC (WAG-7), NRF (WAG-8), and ANL-W (WAG-9) (see Figure 1-1). The following sections discuss the source term screening, radionuclide inventory, and release rate for the source term assessed in the Composite Analysis.

\subsection{Source Term Screening}

Although there are many potential aquifer contamination sources at the INEEL, most of them do not and will not significantly influence the groundwater dose downgradient from the LLW disposal facility. Contaminant source sites and contaminants of potential concern (COPCs) were evaluated on the basis of: (1) proximity of the source to the RWMC, (2) source location with respect to the groundwater flow path that passes beneath the RWMC, (3) risk estimates from Waste Area Group RI/FS studies, and (4) CERCLA assumptions on the future risk posed by co-located facilities. Potential dose from gas-phase radionuclides via the air pathway is negligible (see Section 4).

\subsubsection{Contaminant Sources Outside The Upgradient Corridor}

The source terms of interest are the buried wastes at the RWMC and any upgradient or downgradient radiological sources with a potential for generating a contaminant plume in the groundwater that may interact with a plume originating at the RWMC. Figure 1-1 presents the locations of the RWMC and other major facilities on the INEEL. All potential radiological sources are within the boundaries of the INEEL. Ingestion of contaminated groundwater is the recognized exposure pathway of primary concern. Therefore, this study focuses on those radiological source terms in the ground that may enhance committed effective dose equivalents (CEDEs) due to concentrations of radionuclides in the groundwater.

The probability that source terms will interact is directly correlated to proximity to the RWMC and location relative to aquifer flow lines. A preliminary screening on the basis of location without regard to source term characteristics was performed to eliminate the detailed evaluation of source terms with little or no probability of interaction. Facilities were retained in the CA on the basis of location relative to the RWMC and groundwater flow direction. A series of groundwater flow paths was constructed using a recent groundwater hydraulic head map (Figure 3-1). This figure illustrates that groundwater flows predominantly from northeast to southwest. A region of interest (i.e. upgradient corridor) defined as the

region where contaminants at the RWMC may interact with those from other sources was developed. The upgradient corridor is defined as the region bounded by flow paths within approximately $5 \mathrm{~km}(3 \mathrm{mi})$ east and west of the RWMC. Figure 3-2 illustrates this area and indicates sources in the shaded area of the figure are excluded from further consideration in the CA because they will not interact with RWMC sources.

PBF/ARA and ANL-W facilities are neither upgradient nor downgradient from the RWMC, but located to the east over streamlines that are roughly parallel to those beneath the RWMC (Figure 3-2). Although, dispersion transverse to the flow direction does occur, dispersion in the flow direction is 


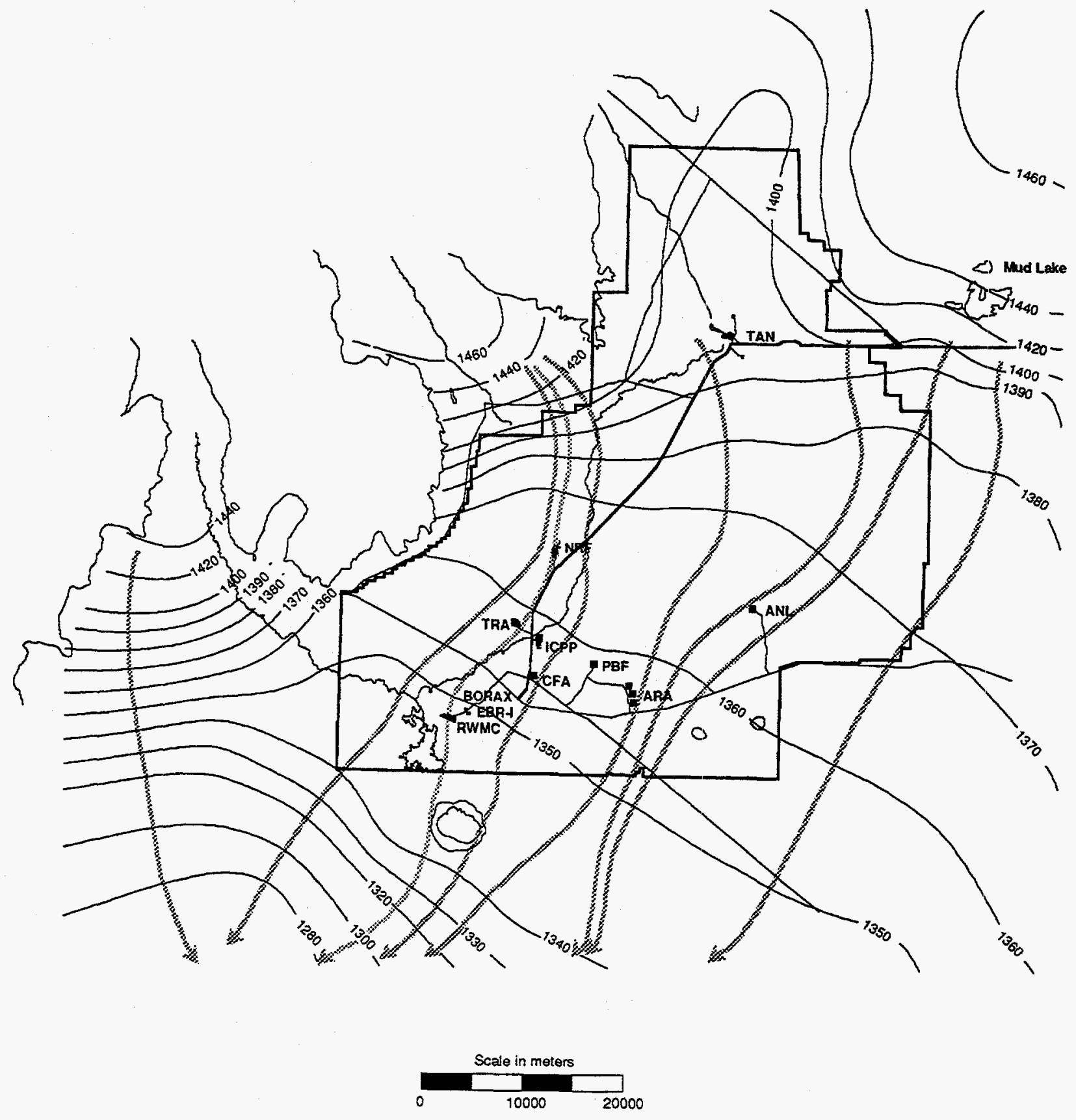

Figure 3-1. Groundwater flow paths at the INEEL. 


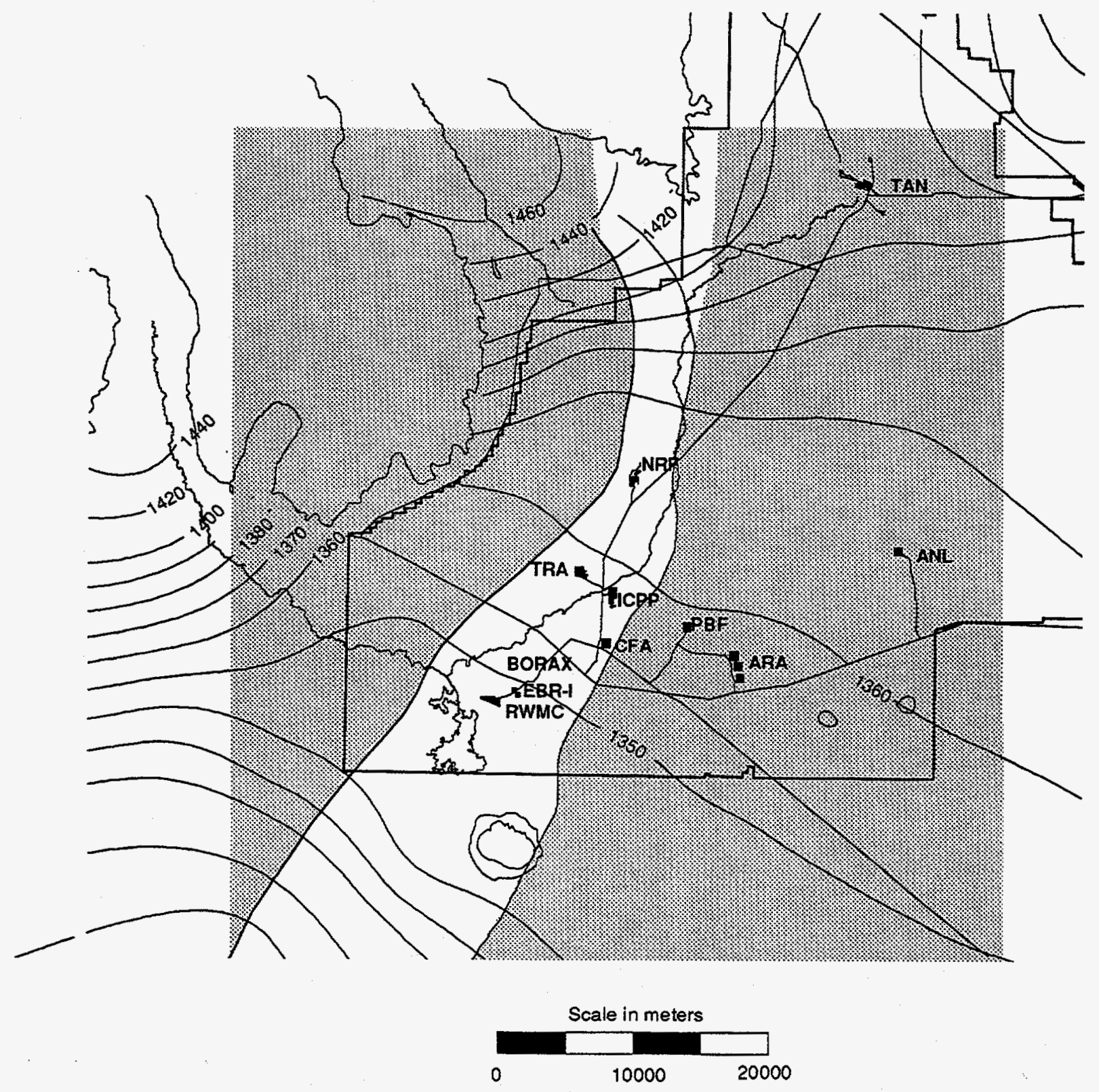

Figure 3-2. Corridor that defines upgradient locations from which contamination will influence potential concentrations at the SDA. 
dominant. Therefore, sources at these facilities are very unlikely to interact with sources at the RIMMC. TAN is located upgradient from the RWMC, but the flow path with a potential to transport contaminants from TAN to the south is located more than $15 \mathrm{~km}(9 \mathrm{mi})$ east of the RWMC along parallel groundwater flow paths. Therefore, facilities screened from the CA on the basis of location relative to the RWMC and parallel groundwater flow path include TAN, PBF/ARA, and ANL-W.

Facilities evaluated further include ICPP, TRA, NRF, CFA, and EBR-I/BORAX. As discussed below, each of these facilities have completed or are currently in the process of CERCLA RI/FS evaluations that define the potential for groundwater contamination from each facility.

\subsubsection{Screening of Sources Within the Upgradient Corridor}

The results of the RI/FS studies for remaining facilities in the upgradient corridor as defined in Section 3.1.1 are summarized below. Where the CERCLA evaluation has not shown any significant risk to the aquifer, the respective facility is then assumed to not contribute to the dose in the vicinity of the RWMC. However, if the CERCLA evaluation does indicate a groundwater risk, then the predicted dose at the RWMC is calculated and evaluated as a possible dose contributor for the groundwater pathway.

Although TRA (WAG 2) is within the upgradient corridor, a Comprehensive RI/FS indicates no unacceptable future groundwater risks are posed by this facility (Burns et al., 1997). Therefore, TRA is excluded from the CA under the assumption that contaminants from TRA will not significantly contribute to the cumulative dose associated with the LLW source term.

Decontamination and dismantlement operations have resulted in the complete removal of all structures in the BORAX (WAG 6) area with the exception of the remains of BORAX-I and the BORAX II-V basement, subbasement, and equipment (Rodman and Stoll, 1994). The RI/FS for BORAX-I indicates no unacceptable future groundwater risks are posed by this facility (Holdren et al., 1995). A Record of Decision (LITCO 1995) was signed to contain the remains of the facility by capping with an engineered long-term barrier comprised primarily of natural materials to maintain effective long-term isolation of contaminants. BORAX II-V was assessed under the CERCLA Track 1 process and a decision was made to contain the remains by placing a concrete cap over the site. This containment is expected to be protective of the groundwater. Therefore, WAG 6 is excluded from the CA on the basis that no significant sources are available that may interact with the active LLW source term.

A Comprehensive RI/FS for CFA (WAG 4) is scheduled for completion by the end of FY98. Historically, work on radioactive and hazardous materials is restricted in and around CFA. An obvious source term does not exist, however should the comprehensive RI/FS identify a potential source term that may interact with the active LLW source term the CA will be revised to consider the new source term.

A Comprehensive RI/FS is near completion for ICPP (WAG 3). Results of the RIFS indicate radionuclides have entered the aquifer at ICPP and will be transported downgradient to the vicinity of the RWMC. Therefore, the 10 radionuclides identified in the ICPP RI report as contaminants of potential concern, i.e., Am-241, Co-60, Cs-137, H-3, I-129, Np-237, Total Pu, Sr-90, Tc-99, and Total U, have been evaluated for their potential to contribute to the dose associated with the RWMC LLW facility. The simulation model developed for the ICPP RI was used to predict future concentrations in the vicinity of the RWMC LLW facility. Table 3-1 summarizes the peak dose contribution for radionuclides contributing greater than $0.01 \mathrm{mrem} / \mathrm{yr}$ all pathways dose near the RWMC resulting from aquifer contamination from the ICPP. The peak dose value is the peak value predicted in the model from the entire area south-west of the RWMC to the boundary of the INEEL. This is a conservative assumption, however, given the 
Table 3-1. Predicted peak doses south-west of the RWMC from the significant ICPP contaminants of potential concern.

\begin{tabular}{lcccc}
\hline Radionuclide & $\begin{array}{c}\text { Peak Concentration } \\
(\mathrm{pCi} L \text { ) }\end{array}$ & $\begin{array}{c}\text { Peak Groundwater } \\
\text { Dose (mrem/yr) }\end{array}$ & $\begin{array}{c}\text { Peak All Pathways } \\
\text { Dose (mrem/yr) }\end{array}$ & Year of Peak \\
\hline $\mathrm{H}-3$ & $1.40 \mathrm{E}+04$ & $6.19 \mathrm{E}-01$ & $1.79 \mathrm{E}+00$ & 1978 \\
$\mathrm{H}-3$ (post 1996) & $5.67 \mathrm{E}+03$ & $2.50 \mathrm{E}-01$ & $7.23 \mathrm{E}-01$ & 1997 \\
$\mathrm{I}-129$ & $2.95 \mathrm{E}+00$ & $5.78 \mathrm{E}-01$ & $1.33 \mathrm{E}+00$ & 2041 \\
$\mathrm{~Np}-237$ & $3.18 \mathrm{E}-01$ & $8.68 \mathrm{E}-01$ & $9.16 \mathrm{E}-01$ & 2721 \\
Total Pu & $6.10 \mathrm{E}-02$ & $1.84 \mathrm{E}-01$ & $1.93 \mathrm{E}-01$ & 21279 \\
TC-99 & $3.56 \mathrm{E}+00$ & $3.24 \mathrm{E}-03$ & $1.07 \mathrm{E}-02$ & 2019 \\
Total U & $2.41 \mathrm{E}-01$ & $4.22 \mathrm{E}-02$ & $4.70 \mathrm{E}-02$ & 2578 \\
\hline \multirow{2}{*}{ a. For total Pu the Pu239 dose conversion factor (DCF) was used because it is largest. } & \\
b. For total U the U234/235 DCF was used because it is higher than the U238 DCF.
\end{tabular}

uncertainty in long term predictions, it is assumed to be a reasonable assumption. Based on the results shown in Table 3-1, during the 1,000 yr compliance period, a total all pathways dose of approximately 1 $\mathrm{mrem} / \mathrm{yr}$ near the RWMC is predicted to result from aquifer contamination from the ICPP. Of these, Np237 will contribute the greatest dose at $0.92 \mathrm{mrem} / \mathrm{yr}$ in the year 2721 .

Since the peak all pathways dose contribution predicted from the ICPP is only $1 \%$ of the DOE primary dose limit of $100 \mathrm{mrem} / \mathrm{yr}$ and only $3 \%$ of the $30 \mathrm{mrem} / \mathrm{yr}$ dose, and is small compared to the predicted dose from the RWMC sources, the cumulative contribution from the ICPP contamination is neglected for the CA.

Remedial investigation activities ongoing at NRF (WAG 9) as well as the operational history of the facility indicate that there is no significant source of radionuclides which could effect the dose contribution of the active LLW disposal facility at the RWMC. The primary source of radionuclides released to the environment at NRF consisted of dilute radioactive water effluent. Between 1953 and 1979 the NRF discharged approximately $1.47 \mathrm{E}+09 \mathrm{~L}(3.9 \mathrm{E}+08 \mathrm{gal})$ of effluent containing a total of approximately $345 \mathrm{Ci}$ of activity; the bulk of the activity being attributed to short-lived activation products. Given that the ICPP dose contribution at the RWMC LLW facility is shown to be negligible, it can be moreover argued that NRF should not receive further consideration as a source because NRF is further upgradient from the RWMC than ICPP and the NRF source term is considerably smaller than that of the ICPP.

A Comprehensive RI/FS for the RWMC (WAG 7) has not been completed at this time. However an interim risk assessment (IRA) which considered wastes disposed in the SDA from inception of burial in 1952 through 1994 has been completed and it indicates other radiological sources within the SDA not associated with the active LLW facility may present future groundwater risks (Becker et al., 1998). The entire source term of WAG-7 (i.e., all historical waste disposals) has been included in the CA, due to its proximity to the RWMC LLW facility. Table 3-3 is a summary of the radionuclides of potential concern for the RWMC WAG 7. 


\subsubsection{Screening of Co-Located Facilities}

The facility screening discussion in Section 3.1.2 is based on those contamination sites defined as CERCLA sites. In addition to the CERCLA sites, there are facilities that are co-located with the CERCLA sites. For example, there are 88 primary facilities at the ICPP that will be closed in the future, and have the potential for radioactive releases to the environment, and the residual contamination in these sites has not been included in the ICPP baseline risk assessment analysis. The approach for integrating these facility closures with the CERCLA restoration is documented in the draft ICPP Feasibility Study report (Rodriguez et al., 1996). It requires that the increase in human cancer incidence resulting from the residual contamination be evaluated and minimized in order to be consistent with the CERCLA remedial action objectives. For purposes of the CA, it is assumed that closure of the co-located facilities at ICPP will satisfy the CERCLA requirements and therefore do not significantly add to the dose from the LLW facility.

\subsubsection{Future Facilities}

An Environmental Impact Statement is presently being prepared to evaluate reasonable alternative process options for dispositioning of high level waste (calcine and sodium bearing waste) accumulated from previous ICPP reprocessing activities. One alternative being considered is for a High Level Waste Treatment Facility and Interim Storage Facility to be located here on the INEEL. The High Level Waste Treatment Facility would consist of a separations operation, extracting the high activity or transuranic wastes which would then be solidified and temporarily stored in the Interim Storage Facility until the waste can be sent off-Site for permanent disposal. The remaining low activity portion of the waste would be grouted and classified as either 10 CFR 61.55 Class A or Class C waste. A permanent low-level nixed waste landfill would potentially be located at the INEEL to store the grouted low activity waste. Since, a final decision has not been made on any of these proposed facilities they will not be addressed in this CA at this time. However, should these facilities be located at the INEEL they will be evaluated in a revised version of the CA to determine if cumulative impacts from these facilities and the active LLW disposal facility and all other potential radioactive sources on the INEEL would adversely affect the potential radiological dose to future members of the public.

\subsubsection{Summary of Source Term Screening}

The evaluation of all major INEEL facilities for potential source term dose contribution at the active LLW disposal facility resulted in three facilities being removed from further consideration on the basis of hydrogeologic considerations. PBF (WAG-5) and ANL-W (WAG-9) are outside the groundwater flow paths flowing beneath the RWMC and lie to the east along parallel flow lines. TAN (WAG-1) is upgradient of the RWMC but lies in a region of flowpaths that run well to the east of the RWMC. Furthermore TAN is considerably distant from the RWMC over $50 \mathrm{~km}$ (31 mi).

The remaining facilities (NRF, TRA, ICPP, CFA, EBR-1/BORAX, and RWMC) with the exception of the RWMC (WAG 7) lie upgradient and are within the flow path of the LLW facility. With the exception of ICPP (WAG-3) and RWMC (WAG-7), each of these facilities was removed from consideration as a source which could effect the dose from the active LLW disposal facility because CERCLA investigation activities and institutional knowledge indicate there is no appreciable risk from the groundwater pathway.

Groundwater contaminant transport simulations indicate that radionuclides released from ICPP (WAG-3) will migrate beneath the RWMC. However, the potential ICPP (WAG-3) contribution to dose from the groundwater pathway is negligible. During the $1,000 \mathrm{yr}$ compliance period, a total all pathways 
dose of approximately $1 \mathrm{mrem} / \mathrm{yr}$ near the RWMC is predicted to result from aquifer contamination from the ICPP. Therefore, ICPP (WAG-3) is removed from further consideration. The source screening does indicate the RWMC (WAG-7) as having the potential to provide significant contribution to the dose from the active LLW disposal facility. All other INEEL sources are eliminated from further consideration. Table 3-2 is a summary of the radionuclides for the RWMC (WAG 7).

Table 3-2. RWMC (WAG 7) radionuclides of potential concern.

\begin{tabular}{ccc}
\hline Ac227 & Nb94 & Sr90 \\
Am241 & Ni59 & Tc99 \\
Am243 & Ni63 & Th228 \\
C14 & Np237 & Th229 \\
C136 & Pa231 & Th230 \\
Cm244 & Pb210 & Th232 \\
C060 & Pu238 & U232 \\
Cs137 & Pu239 & U233 \\
Eu152 & Pu240 & U234 \\
Eu154 & Pu241 & U235 \\
H3 & Pu242 & U236 \\
I129 & Ra226 & U238 \\
Na22 & Ra228 & \\
\hline
\end{tabular}

\subsection{Composite Analysis Source Term}

The source term used in the Composite Analysis consists of all historical subsurface disposals of radionuclides as well as the authorized LLW subsurface disposal inventory and projected LLW subsurface disposal inventory. The Composite Analysis source term was developed from CIDRA and subsequent modifications of CIDRA data for specific radionuclides.

LLW subsurface disposal at the RWMC is controlled by the waste acceptance criteria as authorized by the RWMC PA (Maheras et al. 1994 and Addendum 1997). The PA analysis included all waste disposed after 1984 and projected LLW disposal to the year 2020. The current waste acceptance criteria do not consider the effect of waste disposed in the SDA prior to 1984. The risk posed by waste disposed in the SDA prior to 1984 is being investigated as part of a CERCLA baseline risk assessment (BRA). The interim results of the investigation have been documented as an IRA (Becker et al., 1998). The IRA source term included all radionuclide contaminants disposed in the SDA, including the current LLW disposals, and was adapted for use in the CA source term. The IRA for the RWMC (WAG-7) used the 1952 to 1993 upper-bound inventory estimate from CIDRA to compute the source term inventory at the SDA; the CA source term uses the 1952 to 2020 best-estimates from CIDRA, as well as modifications for TRA, ANLW, NRF, and SMC inventories. Table 3-3 lists the Composite Analysis source term. The data are divided into the actual LLW disposals, the projected disposals through the year 2020 , and total. 
Table 3-3. Composite Analysis source term inventory by date of disposal.

\begin{tabular}{|c|c|c|c|}
\hline Radionuclide & $\begin{array}{c}\text { Actual } \\
(1952-1993)\end{array}$ & $\begin{array}{c}\text { Projected } \\
(1994-2020)\end{array}$ & $\begin{array}{c}\text { Total } \\
(1952-2020)\end{array}$ \\
\hline$\overline{\mathrm{Am}-241}$ & $1.60 \mathrm{E}+05$ & $4.72 E+00$ & $1.60 \mathrm{E}+05$ \\
\hline Am-243 & 2.27E-01 & $0.00 \mathrm{E}+00$ & $2.27 \mathrm{E}-01$ \\
\hline C-14 & $5.04 \mathrm{E}+02$ & $1.57 \mathrm{E}+02$ & $6.61 E+02$ \\
\hline Cl-36 & $3.14 \mathrm{E}-01$ & $0.00 \mathrm{E}+00$ & $3.14 \mathrm{E}-01$ \\
\hline $\mathrm{Cm}-244$ & $7.01 E+01$ & $5.18 \mathrm{E}-01$ & $7.06 \mathrm{E}+01$ \\
\hline $\mathrm{Co}-60$ & $4.09 E+06$ & $1.92 E+06$ & $6.01 E+06$ \\
\hline Cs-137 & $6.17 \mathrm{E}+05$ & $4.26 \mathrm{E}+03$ & $6.21 E+05$ \\
\hline Eu-152 & $2.41 E+02$ & $1.87 \mathrm{E}+00$ & $2.42 E+02$ \\
\hline Eu-154 & $2.95 \mathrm{E}+03$ & $3.71 E+00$ & $2.96 E+03$ \\
\hline $\mathrm{H}-3$ & 4.52E+06 & $2.66 \mathrm{E}+06$ & $7.18 \mathrm{E}+06$ \\
\hline I-129 & $6.45 \mathrm{E}-02$ & $1.35 \mathrm{E}-01$ & $2.00 \mathrm{E}-01$ \\
\hline $\mathrm{Na}-22$ & $8.40 \mathrm{E}-01$ & $2.52 \mathrm{E}-01$ & $1.09 \mathrm{E}+00$ \\
\hline $\mathrm{Nb}-94$ & $5.08 \mathrm{E}+01$ & $1.92 \mathrm{E}+00$ & $5.27 E+01$ \\
\hline $\mathrm{Ni}-59$ & $6.30 \mathrm{E}+03$ & $1.98 \mathrm{E}+02$ & $6.50 \mathrm{E}+03$ \\
\hline $\mathrm{Ni}-63$ & $1.11 \mathrm{E}+06$ & $1.52 E+05$ & $1.26 \mathrm{E}+06$ \\
\hline $\mathrm{Np}-237$ & $1.84 \mathrm{E}+00$ & $0.00 \mathrm{E}+00$ & $1.84 E+00$ \\
\hline Pu-238 & $2.45 E+03$ & $1.11 \mathrm{E}+00$ & $2.45 \mathrm{E}+03$ \\
\hline Pu-239 & $6.36 \mathrm{E}+04$ & $1.13 \mathrm{E}+00$ & $6.36 \mathrm{E}+04$ \\
\hline $\mathrm{Pu}-240$ & $1.46 \mathrm{E}+04$ & $1.22 \mathrm{E}-01$ & $1.46 \mathrm{E}+04$ \\
\hline $\mathrm{Pu}-241$ & $3.87 \mathrm{E}+05$ & $1.25 \mathrm{E}+02$ & $3.87 \mathrm{E}+05$ \\
\hline $\mathrm{Pu}-242$ & $9.61 \mathrm{E}-01$ & $0.00 \mathrm{E}+00$ & $9.61 \mathrm{E}-01$ \\
\hline Ra-226 & $5.99 \mathrm{E}+01$ & $0.00 \mathrm{E}+00$ & $5.99 \mathrm{E}+01$ \\
\hline $\mathrm{Ra}-228$ & $0.00 \mathrm{E}+00$ & $0.00 \mathrm{E}+00$ & $0.00 \mathrm{E}+00$ \\
\hline Sr-90 & $4.52 \mathrm{E}+0.5$ & $0.00 \mathrm{E}+00$ & 4.52E+05 \\
\hline Tc-99 & $2.63 \mathrm{E}+01$ & $1.08 \mathrm{E}-01$ & $2.64 \mathrm{E}+01$ \\
\hline Th-228 & $1.02 E+01$ & $0.00 \mathrm{E}+00$ & $1.02 \mathrm{E}+01$ \\
\hline Th-230 & $1.79 \mathrm{E}-02$ & $0.00 \mathrm{E}+00$ & $1.79 \mathrm{E}-02$ \\
\hline Th-232 & $1.32 E+\infty 0$ & $0.00 \mathrm{E}+\infty 0$ & $1.32 \mathrm{E}+00$ \\
\hline U-232 & $1.06 \mathrm{E}+01$ & $0.00 \mathrm{E}+00$ & $1.06 \mathrm{E}+01$ \\
\hline U-233 & $1.15 \mathrm{E}+00$ & $0.00 \mathrm{E}+00$ & $1.15 \mathrm{E}+00$ \\
\hline U-234 & $6.49 E+01$ & $9.88 \mathrm{E}-02$ & $6.50 \mathrm{E}+01$ \\
\hline $\mathrm{U}-235$ & $5.12 \mathrm{E}+00$ & $4.58 \mathrm{E}-03$ & $5.13 E+00$ \\
\hline U-236 & $2.14 \mathrm{E}+00$ & $1.62 \mathrm{E}-02$ & $2.16 \mathrm{E}+00$ \\
\hline U-238 & $1.12 E+02$ & $1.18 \mathrm{E}-01$ & $1.12 \mathrm{E}+02$ \\
\hline
\end{tabular}




\section{COMPOSITE PERFORMANCE ANALYSIS}

The methodology used to assess the potential migration of radionuclides from the various sources and the resulting doses to a potential receptor consists of: (1) modeling the source term and release using the DUST-MS code, (2) using the DUST-MS output as input to the TETRAD subsurface transport modeling code, (3) using the output from TETRAD (radionuclide groundwater concentrations) as exposure concentrations in the exposure scenarios, and (4) calculating the predicted radiological dose to the public. Included in this section are a description of the Composite Analysis source term release and transport, exposure scenarios, and the Composite Analysis results.

\subsection{Source Term Release and Transport}

The modeling performed for the Composite Analysis relies extensively on both the results and the methodology of recent modeling efforts conducted for the RWMC (WAG-7) IRA (Becker et al. 1998; Magnuson and Sondrup, 1998). Guidance for the Composite Analysis stipulates use of best-estimate waste inventory data however, the IRA used upper-bound waste inventory estimates. For the lesser or low-risk radionuclides, the results of the IRA (Becker et al., 1998) were scaled to provide groundwater concentrations based on the best-estimate waste inventory data and projected waste disposal. Section 4.1.4 describes the methodology used for scaling and shows how well the scaled radiological doses match the best-estimate radiological dose simulations. The groundwater simulations were rerun with best-estimate waste disposal inventories for the major radiological risk drivers (C-14, I-129, Np-237, Tc-99, U-234, and U-238) identified in the IRA.

\subsubsection{Source Term Model}

DUST-MS was used to predict releases from buried waste into the shallow subsurface by modeling container failure and eventual release from the waste (Sullivan 1993). DUST-MS is a one-dimensional model that has three waste form release mechanisms: surface washoff, diffusion, and dissolution. The surface washoff model can be used to estimate the release from general laboratory trash and is equivalent to the first-order leach model used in other codes such as GWSCREEN (Rood 1994). The diffusion model computes the diffusion release from different waste geometries based on user-supplied diffusion coefficients for each waste form. Diffusion of contaminants from cement-encased waste was estimated with the diffusion release model. The dissolution release model was used to estimate the release caused by general corrosion such as the release of activated metals from the corrosion of the base metal. The simulated mass release is then used as input into the subsurface flow and transport model that was developed with the TETRAD transport modeling code (Vinsome and Shook 1993). Because the release and transport were calculated for a large number of radionuclides, the radionuclides were grouped for fate and transport simulation. Members of a decay chain were in a single group. Other radionuclides with similar retardation values were also grouped. Isotopes in the chain with a half-life of more than one year were included in the simulations. Shorter half-life contaminants were handled by assuming they were in equilibrium with the longer half-life parent and adding the respective toxicity values. This grouping was used in the source term simulations to provide a consistent set of inputs for all of the simulations. Inputs for the source term model are discussed below and include: (1) waste inventory source term, (2) container failure rates, and (3) waste stream and contaminant-specific release rates.

4.1.1.1 Waste Inventory Source Term. The source term used in the CA is the latest CIDRA (LMITCO 1995a; LMITCO 1995b) inventory with supplemental data for data gaps identified and reconciled in key waste streams from ANL-W, NRF, TRA, and the SMC at TAN for radionuclides critical 
to the performance of the active LLW disposal pits at the SDA. The waste stream updates will be incorporated into CIDRA. Carboneau (1998) provides a reassessment of neutron activation product radionuclides in EBR-II core non-fuel bearing structural metal hardware disposed from ANL-W. Abbott (1997a,b) and Bradley (1998) provide refined estimates of key environmental radionuclides in NRF core structural waste and expended ion exchange resin waste disposed in the SDA. Schnitzler (1995) calculated refined estimates of the radionuclide inventories in ATR beryllium (Be) reflector blocks and outer shim control cylinders. The data of Schnitzler (1995) were extrapolated by Honeycutt (1998) to estimate the inventory of selected radionuclides in the reported Be block disposals from TRA. Sterbentz (1998) has calculated key environmental radionuclide estimates for all core components removed from the ATR core per the Core Internal Change-out schedules, the ATR core component inventory disposed in the RWMC SDA is not determined therefore, the estimate provides a conservative upper limit. Schnitzler (1998) has calculated an estimate of C-14 production in ATR coolant, providing a basis for the determination of Abbott (1998) for estimated C-14 inventory in TRA resin disposal shipments to the SDA.

Past radiological disposals were decayed to the present, then release simulations were performed. Yearly waste disposal inventory was used in the Composite Analysis to allow decay and release calculations to begin at the actual year of disposal. This approach prevents underestimation of mobile contaminants with short half-lives. DUST-MS was modified to allow a delay time to be input. Decay and release calculations did not commence until after the input delay time. Inputting the yearly disposal quantity with the appropriate delay time allows direct input of the yearly quantities of contaminants without having to correct for decay until the year of disposal. Validation cases were run to ensure that this change did not affect the release models other than delaying the start of release calculations.

4.1.1.2 Container Failure Rates. Before a contaminant can be released to the environment from the waste form, the containment in which the waste is buried must first degrade. If a contaminant is buried in drums, the contaminant will not be released until the drums are breached. DUST-MS allows the user to specify the time until container failure. If the waste disposal were performed without containment, then the failure time is set at zero and the release mechanisms control the release of the contaminants from the waste. Once the container is breached, the waste is released to the subsurface according to the release mechanisms that are appropriate for that waste stream.

The source term model used the yearly disposal information to assign container type for calculation of the release. In the model, each container had a prescribed time until failure from the time of emplacement. A single contaminant might reside in multiple containers buried in a given year because of the different waste form or different containment to be modeled. For example, if the disposal contents of a particular waste stream were buried in metal containers and in cardboard boxes, two container types would be used to model that year's disposal. One container type would be for the amount of the inventory in the metal containers, and the other container type would be for the amount in cardboard boxes.

Individual waste streams were evaluated for the type of containment used. The disposal contents of many waste streams were buried in wood or other readily degradable boxes. It was assumed that these readily degradable "containers" do not hinder contaminant movement; therefore, no delay of the contaminant release was assumed for the boxes in the model. Polyethylene bags were not accounted for in the release modeling either. This is a conservative assumption for contaminants other than tritium and carbon-14 that may be present in the gas-phase. The 55-gal drums, concrete casks, and metal boxes offer a barrier to contaminant release that is accounted for in the source term model. Waste in the containers is released only after the drums, casks, or metal boxes are assumed to have failed. Waste streams listed as " $O$ " (other) in CIDRA, or as a mix of containment types without a breakdown of the actual amounts in each type, were modeled as having no containment. 
The carbon steel corrosion rate (see Table 4-1) was used to determine the failure time of the metal boxes. Release from concrete casks was modeled as a diffusion release from a nominal $15 \mathrm{~cm}$ (6-in.) wall thickness cylinder. Using this thickness assumption is conservative for early releases because it assumes that the waste is at the surface of the cask and is readily released. In addition, a conservative diffusion endpoint of $1.0 \mathrm{E}-06 \mathrm{~cm}^{2} / \mathrm{g}$ was used. This is a typical diffusion coefficient for a metal ion in water and is conservative because it does not account for the possible partitioning of the contaminant with the waste form or the porous media that the contaminants must travel through. Any partitioning would slow the contaminant release.

The majority of the containers buried in the SDA are 55-gal drums. A separate study was performed to determine the failure rate of these drums using data gathered during earlier waste retrieval efforts (Becker 1997). The study indicates dumped drums fail more rapidly than stacked drums. Therefore, the two drum disposal methodologies are treated accordingly.

4.1.1.3 Release Mechanisms. DUST-MS has three release models: (1) diffusion, (2) dissolution, and (3) surface washoff. Each contaminant's yearly disposal has been proportioned among the release mechanisms. The percent in a release mechanism is input into DUST-MS. The total disposal inventory has been analyzed to determine the release mechanism and release rate as a function of the waste stream contents put in storage in any given year. Because each contaminant has a unique set of information, each year's disposal for each contaminant is modeled as a separate waste container. The results are summed to provide the total release over the time interval for input into the transport models. Table 4-1 is a summary of the release rate information for the different release models.

Waste streams that have metal listed as the primary waste form can be either a dissolution release (corrosion of the base metal) of activation products or surface washoff (contamination on the metal). Metal waste streams will generally be a surface washoff release for actinides and fission products and dissolution (corrosion) for activation products. Table 4-2 lists the grouping and release mechanism for radionuclides having metal waste streams. Actinides and fission products are surface contaminants on the base metal. The activation products are the result of activation of the base metal and generally are released only as the metal corrodes. Activation products such as Na-22 produced within the coolant and not in the structural components are modeled as surface contamination using the surface washoff model.

For the CA, the corrosion rate of $4,500 \mathrm{yr} / \mathrm{mm}$ for stainless steel was taken from Nagata (1997). For metals other than stainless steel such as uranium, the release of the metal into the subsurface is dependent on the chemical properties of the soil water and the solubility of that metal in the INEEL pore water conditions. The soil water has a high $\mathrm{pH}$, causing many contaminants to have a low solubility. To simulate the release of metals like uranium, the surface washoff model has been used with the appropriate solubility limit (Becker et al., 1998; Section 5.2) for the INEEL soil water chemistry.

A surface washoff release mechanism is also used for waste streams that are generic laboratory trash. The surface washoff release mechanism provides the most conservative release rates. Similarly, contaminants identified as surface contamination of a base material, such as radionuclides on anticontamination clothing, are modeled with the surface washoff model. The surface washoff model uses a partition coefficient to determine the release. As a first approximation, the soil-to-water partition coefficient was used. 
Table 4-1. Release rate coefficients.

\begin{tabular}{|c|c|c|c|}
\hline Contaminant Release & Model Used & Rate & Comment \\
\hline $\begin{array}{l}\text { Release from Be } \\
\text { corrosion (diffusion is } \\
\text { negligible) }\end{array}$ & Dissolution & $3.0 \mathrm{E}-04 / \mathrm{yr}$ & Nagata (1993) \\
\hline $\begin{array}{l}\text { Release from corrosion } \\
\text { of stainless steel }\end{array}$ & Dissolution & $4,500 \mathrm{yr} / \mathrm{mm}$ & Nagata (1997) \\
\hline $\begin{array}{l}\text { Release from corrosion } \\
\text { of carbon steel }\end{array}$ & Dissolution & 450 to $680 \mathrm{yr} / \mathrm{mm}$ & $\begin{array}{l}\text { Banaee and Nagata } \\
\text { (1996) }\end{array}$ \\
\hline Release by leaching & Surface washoff & $\begin{array}{l}\text { Soil-to-water partition } \\
\text { coefficients }\end{array}$ & Dicke (1997) \\
\hline Release from resin & Surface washoff & $\begin{array}{l}\text { Soil-to-water partition } \\
\text { coefficients }\end{array}$ & Dicke (1997) \\
\hline $\begin{array}{l}\text { Release of metal by } \\
\text { corrosion }\end{array}$ & Surface washoff & Contaminant solubility & Dicke (1997) \\
\hline
\end{tabular}

Table 4-2. Metal waste stream release mechanisms.

\begin{tabular}{lcc}
\hline \multicolumn{1}{c}{ Group } & Release Mechanism & Contaminant \\
\hline Fission products & Surface washoff & Cs-137, Eu-154, I-129, Sr-90 \\
Activation products & Dissolution & C-14, Co-60, Ni-59, Ni-63, Nb-94, Tc-99 \\
Actinides & Surface washoff & Am-243, Cm-244, Np-237, Pu, U \\
\hline
\end{tabular}


Table 4-3 shows the percentage of the disposal of each radionuclide in resins. C-14 in ion exchange resin constitutes a significant potentially mobile fraction. Therefore, it was conservatively assumed that release from ion exchange resin was at the lower end of the $\mathrm{K}_{\mathrm{d}}$ range for $\mathrm{C}-14$ in soil, or $0.1 \mathrm{~mL} / \mathrm{g}$. The release from resins was then modeled using the more conservative surface washoff release based on the soil-to-water partition coefficients.

Beryllium corrosion was studied for the revised SDA scoping risk assessment (Burns et al., 1994) and the RWMC performance assessment (Maheras et al., 1994). Beryllium corrosion primarily controls the release of $\mathrm{H}-3$ and $\mathrm{C}-14$ because beryllium reflector blocks contain most of the $\mathrm{H}-3$ and $\mathrm{C}-14$ that was disposed. The predicted fractional release is within a factor of three for the two studies. The Nagata (1993) study results were used in the Composite Analysis.

Table 4-3. Percentage of contaminant disposal in resins.

$\%$ of Individual

Isotope Disposed

Radionuclide

C-14

Cm-244

Co-60

Cs-137

Eu-154

I-129

Ni-59

Ni-63

Pu-238

Pu-239

$\mathrm{Pu}-240$

Pu-241

Pu-242

Sr-90

U-234

U-236
Waste Stream Number

TRA-603-1H

TRA-603-1H

TRA-603-1H

TRA-603-1H

TRA-603-1H

TRA-603-1H

TRA-603-1H

TRA-603-1H

TRA-603-1H

RFO-DOW-13H

RFO-DOW-13H

RFO-DOW-13H

RFO-DOW-13H

TRA-603-1H

TRA-603-1H

TRA-603-1H of in Resins

\section{1}

25.7

2.5

7.0

39.3

9.8

6.9

3.7

1.2

1.1

1.1

1.1

1.0

9.8

1.0

10.9 
4.1.1.4 Pit and Trench Grouping. The pits and trenches were grouped for the simulations because DUST-MS is a one-dimensional model that cannot model them individually without numerous separate simulations. Separate simulations were impractical considering the number of contaminants to analyze for in each pit and trench. In addition, the exact disposal location is not always available. An analysis of the contaminant disposal shows a distinct difference in the waste types buried before 1970 and after 1970 . Current LLW waste disposal (waste buried during 1984 and after) must meet contemporary SDA waste acceptance criteria. Before 1970, hazardous, mixed, LLW, and TRU waste were accepted for disposal at the SDA. After 1970, TRU waste was no longer accepted. After 1984, hazardous and mixed waste was no longer accepted. Therefore, the waste was divided into three groups based on the time that the pit or trench was open. Pits and trenches opened before 1970 were in one group, pits and trenches opened after 1970 but before 1984 were in a second group, and pits opened after 1984 were in a third group. The simulated source release from the three waste stream groups was input into the subsurface pathway model as shown in Figure 4-1. Figures 4-2 and 4-3 show the simulated DUST source releases for the radionuclides that were resimulated in the Composite Analysis.

\subsubsection{Subsurface Model}

The subsurface model was developed in stages. First, a flow model was developed that describes the movement of water in the subsurface. This model includes hydraulic descriptions of each lithologic material in the subsurface and boundary conditions related to water sources both from infiltration of water at the surface and from horizontal movement of water within the SRPA. Calibration of the flow model was obtained by adjusting hydraulic input parameters in the model until simulated water movement agreed with observed water level measurements. Second, a transport model was developed describing the movement of contaminants dissolved in either water or in air. Contaminant release time histories obtained from the source term model were input into the subsurface model and were described in Section 4.1.1. The transport model consists of parameterizing dispersion, diffusion, decay, and sorption and describing additional boundary condition effects that affect pressure and therefore advection within the gaseous phase. Aqueous phase advection was parameterized by the flow model. Calibration data is limited but calibration of the transport model, to the degree possible, was achieved by comparing simulated concentrations of indicator contaminants to observed aquifer concentrations and adjusting transport parameters and boundary conditions to improve the agreement. The flow-and-transport model was used to make predictive simulations for the radionuclides identified in the source term screening in Section 3. A complete description of the subsurface model developed and used for predictive simulation can be found in Magnuson and Sondrup (1998). A brief overview of the model is presented in the following section.

\subsubsection{Conceptual Model for Flow and Transport. Contaminant fate and transport was} simulated for contaminants that exist in a dissolved or aqueous phase and for contaminants such as tritium that could simultaneously exist in both aqueous and gaseous phases. The general conceptual model for flow treats water movement as if the subsurface consisted of a heterogeneous, anisotropic porous medium. Infiltration of meteoric water into the subsurface could be either transient or described by constant average infiltration rates. The surficial sediments and sedimentary interbeds are simulated with varying thicknesses and upper surface elevations. Known gaps in the interbeds are included in the model. In the fractured basalt portion of the subsurface, flow is considered to only occur within the fracture network to emulate a medium with a low effective porosity but high permeability. Movement of water within the SRPA is assumed to be steadystate given the long time duration of hundreds to thousands of years considered in the subsurface pathway model.

For the dissolved-phase transport conceptual model, the processes that were considered were advection, dispersion, diffusion, radioactive chain decay and ingrowth, and adsorption onto solid surfaces. 

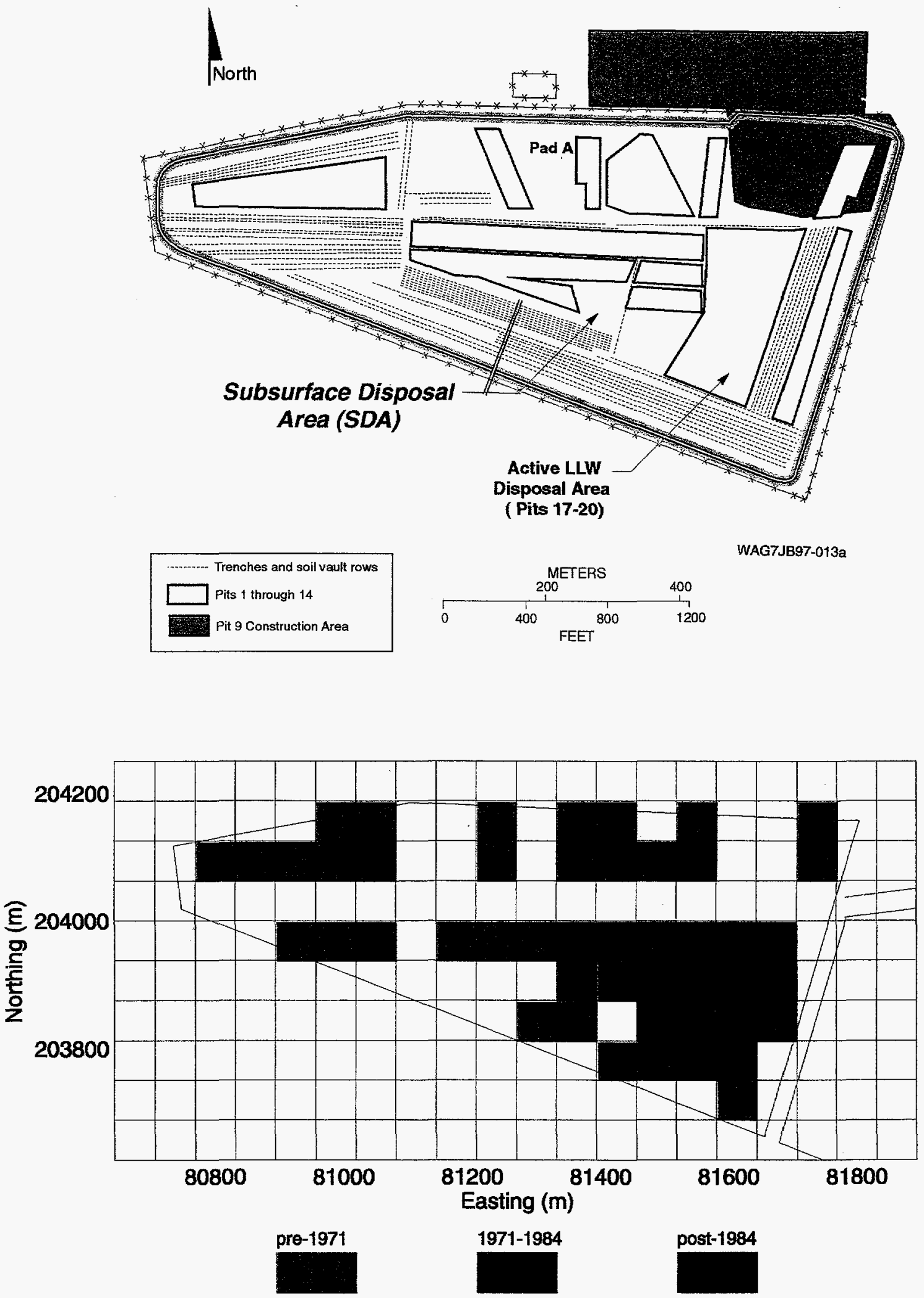

WAG7JB97-013a

Figure 4-1. Distribution of three waste streams into the third level of grid refinement of the subsurface model. 
Pu242
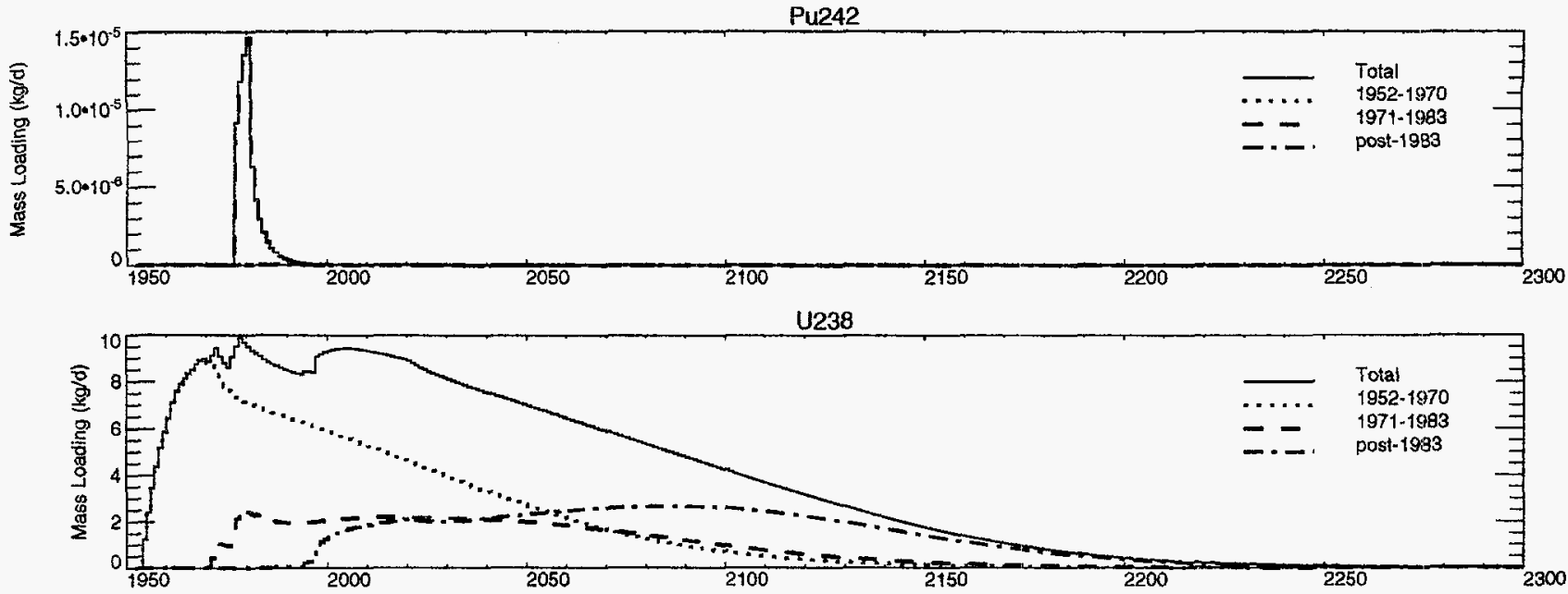

U234

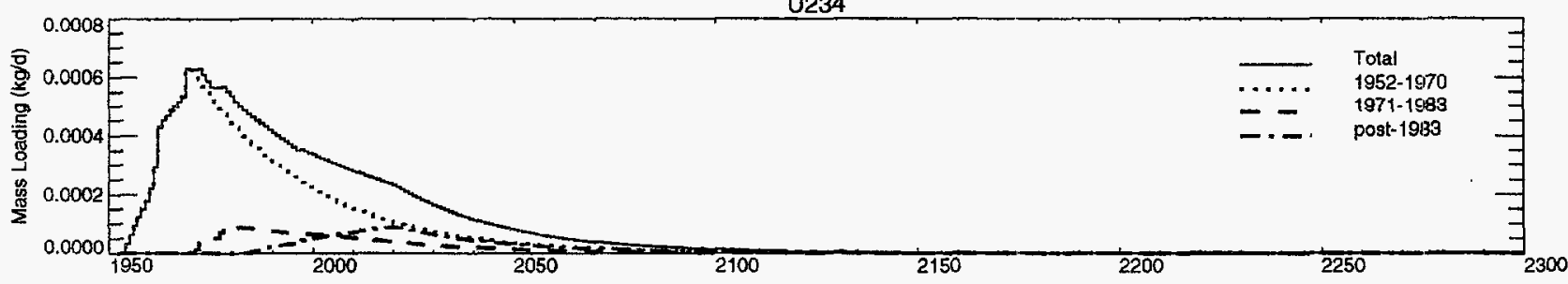

Pu238
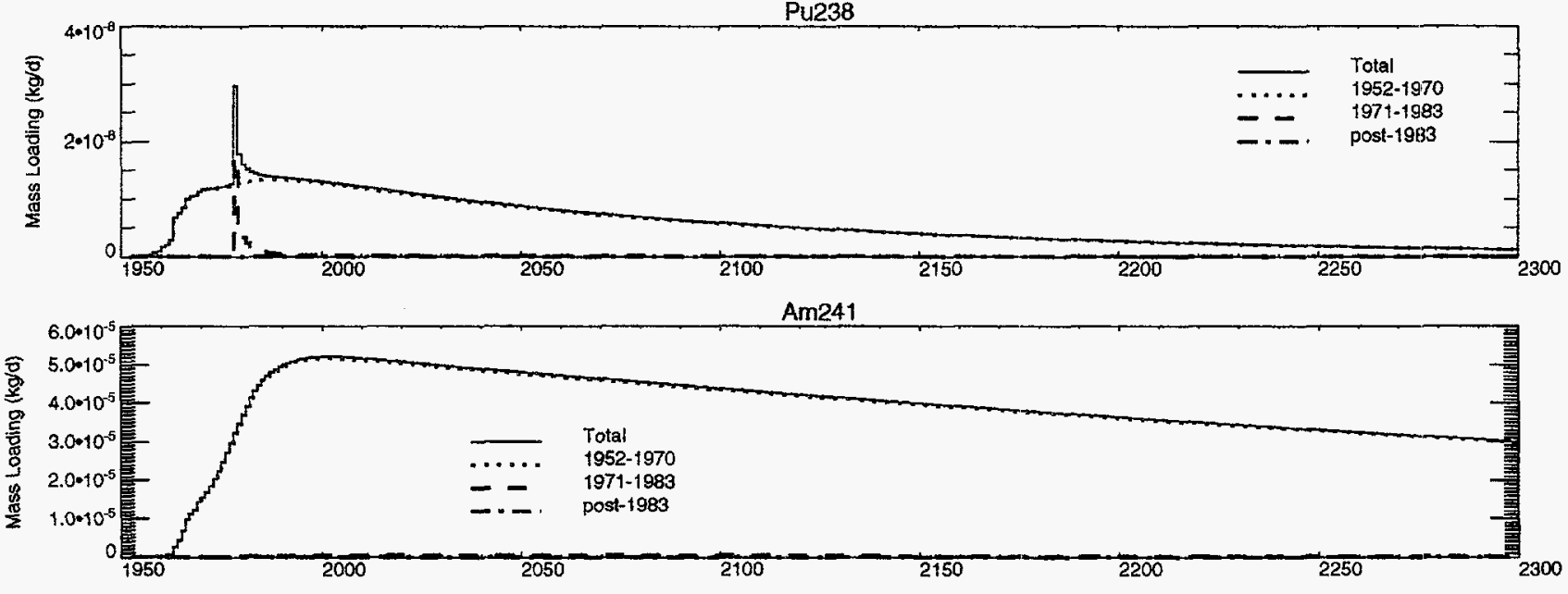

Np237

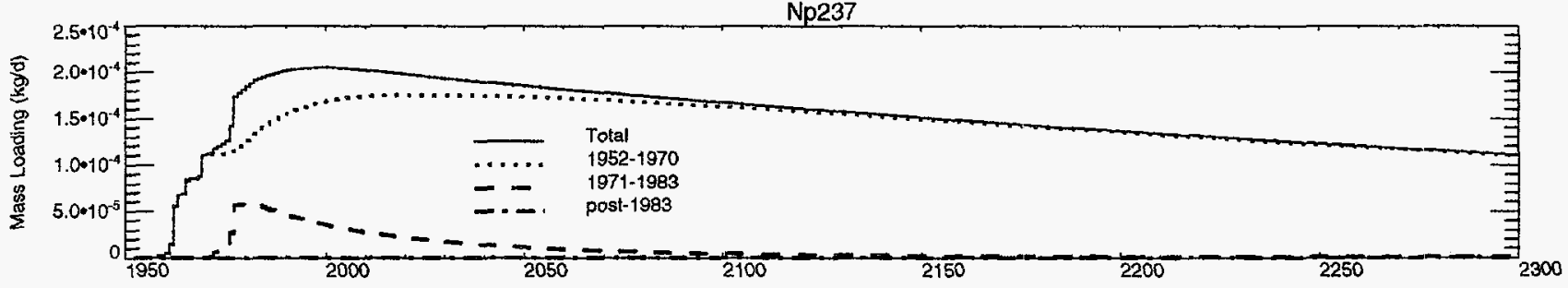

Figure 4-2. Simulated DUST source releases for uranium and other actinides. 

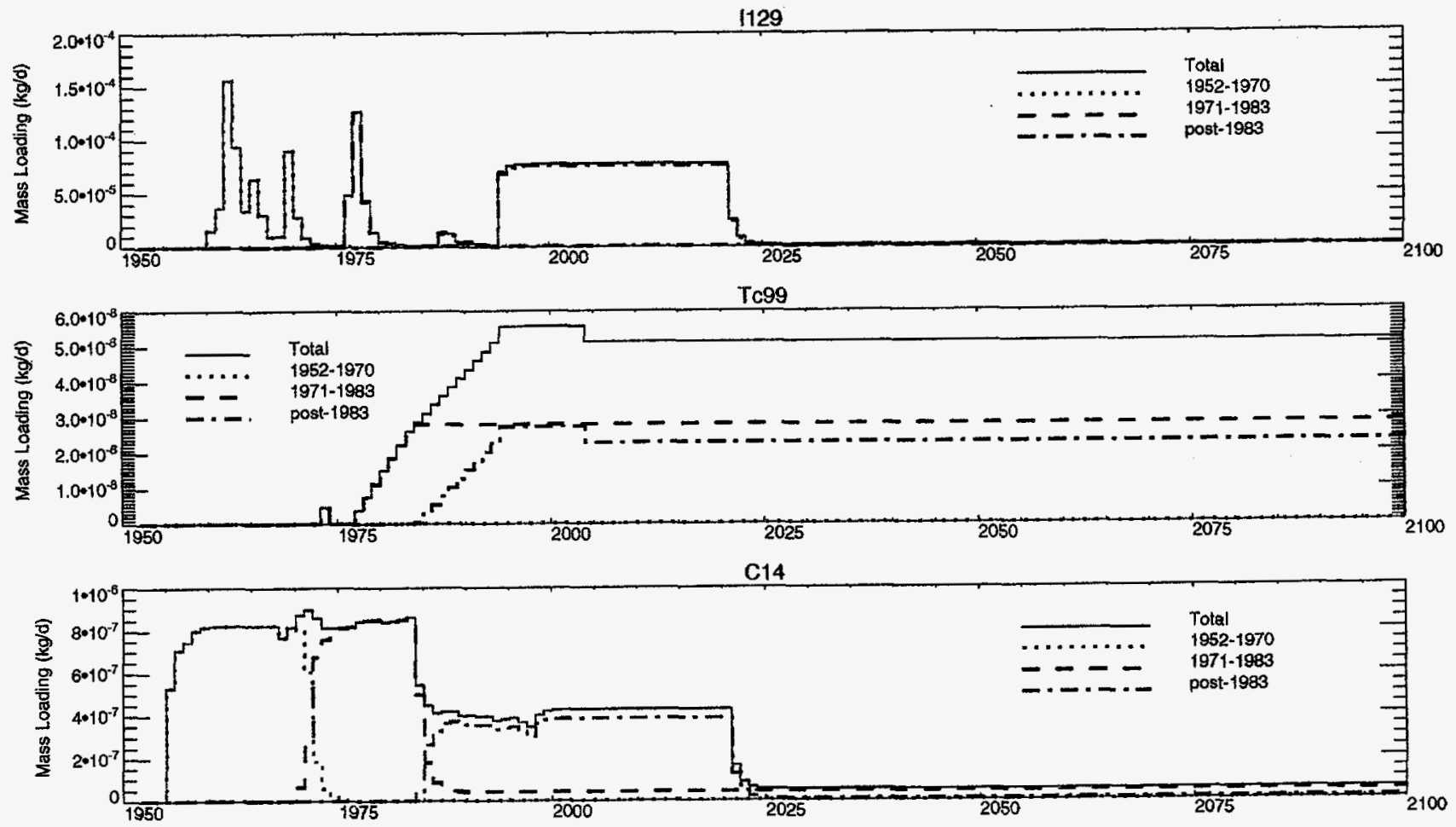

Figure 4-3. Simulated DUST source releases for I-129, Tc-99, and C-14. 
Because modeled water movement in the basalt was restricted to the fractures, sorption in these same regions was restricted to the surfaces of those fractures. Fracture surfaces were considered lined with either fine-grained sediments or chemical alteration products that resulted from water movement along the fractures over extended periods of time. This treatment of sorption necessitated only $\mathrm{K}_{\mathrm{d}}$ values for sorption onto sediments and did not require estimates of sorption onto the basalt matrix itself. Because the sediment lining the basalt fractures make up a small portion of the basalt region of the model, the basalt $K_{d}$ values were scaled down from the sediment $\mathbf{K}_{d}$ values. This scaling resulted in basalt $\mathbf{K}_{d}$ values that are small for all contaminants and negligible for all contaminants with sediment $K_{d}$ values less than $1,000 \mathrm{~mL} / \mathrm{g}$. The $\mathrm{K}_{d}$ values used in the model (Table 4-4) were assigned based on best-estimate values from Dicke (1997), rather than conservative screening values.

Facilitated transport mechanisms, such as colloidal transport, are possible beneath the SDA. However, these transport mechanisms have not been documented as taking place at the SDA therefore, facilitated transport mechanisms have not been included in the transport conceptual model.

Single isolated detections of contaminants have occurred in subsurface contaminant monitoring at the SDA. While these detections may be real, it is not feasible with the current modeling approach to try to emulate each and every one of these isolated detections. Rather the subsurface transport model attempts to mimic the large-scale overall behavior of contaminants in the subsurface. This means the model attempts to emulate those contaminants that are consistently present in a distributed sense in the subsurface. Therefore, for purposes of model calibration, these isolated detections are neglected.

For contaminants that also migrate in the gaseous phase, such as tritium, the conceptual model was expanded to include a dual-porosity approach in which the contaminants could also diffuse or advect into the low permeability basalt matrix from fractures within the basalt. However, the majority of water and contaminant movement still occurred within the fractures in the basalt. Influences on advective movement of gaseous phase contaminants from barometric pressure fluctuations at the surface, positive pressure air injection during drilling of wells in the SDA, and the effects of several vapor-vacuum extraction remedial activities were also considered. Advective flux of contaminants out of the simulation domain was allowed at perimeter locations in the model.

4.1.2.2 Simulation Code. The TETRAD code (Vinsome and Shook 1993) was used to simulate flow and contaminant transport. Documentation of the selection process is discussed in Becker et al., (1996). Verification and validation (Shook 1995; Magnuson 1996) were conducted to demonstrate the proticiency of the TETRAD simulator for use in modeling subsurface fate and transport at the SDA.

TETRAD has complete multi-phase (aqueous, gaseous, and oleic), multi-component simulation capabilities. TETRAD uses a block-centered finite-difference approach and has capabilities for local grid refinement, which were used extensively. The TETRAD simulator also includes dual porosity simulation capabilities. This feature was used to address gaseous phase movement in both the fracture and matrix portions of the fractured basalts composing the majority of the subsurface beneath the SDA.

4.1.2.3 Model Implementation. To achieve a representative flow simulation, spatially variable thicknesses of the surficial sediments, sedimentary interbeds, and fractured basalts composing the subsurface were included in the modeling effort. Data from ninety-two wells in the SDA vicinity were used to generate the surfaces and thicknesses of each lithologic unit. These surfaces and thicknesses were then mapped onto a three-dimensional simulation grid that extended from land surface to the effective depth [76 $\mathrm{m}(249 \mathrm{ft})]$ of the SRPA in the vicinity of the SDA. The horizontal simulation domain extended from north 
Table 4-4. Soil-to-water distribution coefficients used in modeling (Dicke 1997).

\begin{tabular}{|c|c|c|}
\hline Element & $\begin{array}{c}\text { Sediment } \mathrm{K}_{\mathrm{d}} \text { (range) } \\
\mathrm{mL} / \mathrm{g}\end{array}$ & Comments \\
\hline Am & $450(450$ to 1,100$)$ & Measured values \\
\hline $\mathrm{C}$ & $0.1(0.1$ to 1.5$)$ & Site-specific values \\
\hline $\mathrm{Cl}$ & 0 & Anionic and will not react with sediments \\
\hline $\mathrm{Cm}$ & $400(400$ to 1,000$)$ & Americium analog \\
\hline Co & $1,000(50$ to 4000$)$ & Site-specific values \\
\hline Cs & $1,000$ (589 to 3255$)$ & Site-specific values \\
\hline Eu & $400(400$ to 1,000$)$ & Americium analog \\
\hline $\mathbf{H}$ & $\mathbf{0}$ & Nonreactive \\
\hline I & $0.1(0.02$ to 5$)$ & Literature values \\
\hline $\mathrm{Nb}$ & $500(100$ to 1,000$)$ & Literature values \\
\hline $\mathrm{Ni}$ & $300(60$ to 2,000$)$ & Literature values \\
\hline $\mathrm{Np}$ & $8(1$ to 80$)$ & Literature values \\
\hline $\mathbf{P u}$ & $5,100(5,100$ to 22,000$)$ & Site-specific values \\
\hline $\mathbf{R a}$ & $575(88$ to 1,890$)$ & Literature values \\
\hline Sr & 60 (35 to 186$)$ & Site-specific values \\
\hline Tc & $\mathbf{0}$ & Site-specific values \\
\hline Th & $500(200$ to 3,000$)$ & Literature values \\
\hline $\mathbf{U}$ & $6(3.4$ to 9$)$ & Site-specific values \\
\hline Ac & $400(400$ to 1,000$)$ & Americium analog \\
\hline $\mathrm{Pb}$ & $270(30$ to 1,000$)$ & Analogs and literature \\
\hline $\mathrm{Pa}$ & $8(1$ to 80$)$ & Neptunium analog \\
\hline
\end{tabular}

of the SDA to the southern INEEL boundary. Known gaps or locations of zero thickness in the sedimentary interbeds were also included in the lithologic representation.

Results from a calibrated modeling study of infiltration using moisture monitoring within the SDA surficial sediments (Martian 1995) were used to define the spatially variable infiltration of water at land surface in the SDA. Martian selected three representative infiltration rates and assigned them to portions of the SDA based on similarity to observed infiltration results and surface topography (see Figure 4-4). Each of the low, medium, and high infiltration rates had a transient description. A constant time-weighted average of Martian's transient averaged rates was examined. A spatial average of the three infiltration rates is $8.5 \mathrm{~cm} / \mathrm{yr}$ ( $3.3 \mathrm{in} / \mathrm{yr})$. The time period for the flow-and-transport calibration simulations was from the beginning of 1952, the year waste was first buried in the SDA, until the end of April 1995, the end of the Martian infiltration simulation study. Estimated amounts of water from the three historical flooding events $(1962,1969$, and 1983) were superimposed on both the transient and constant infiltration surfaceboundary conditions. 


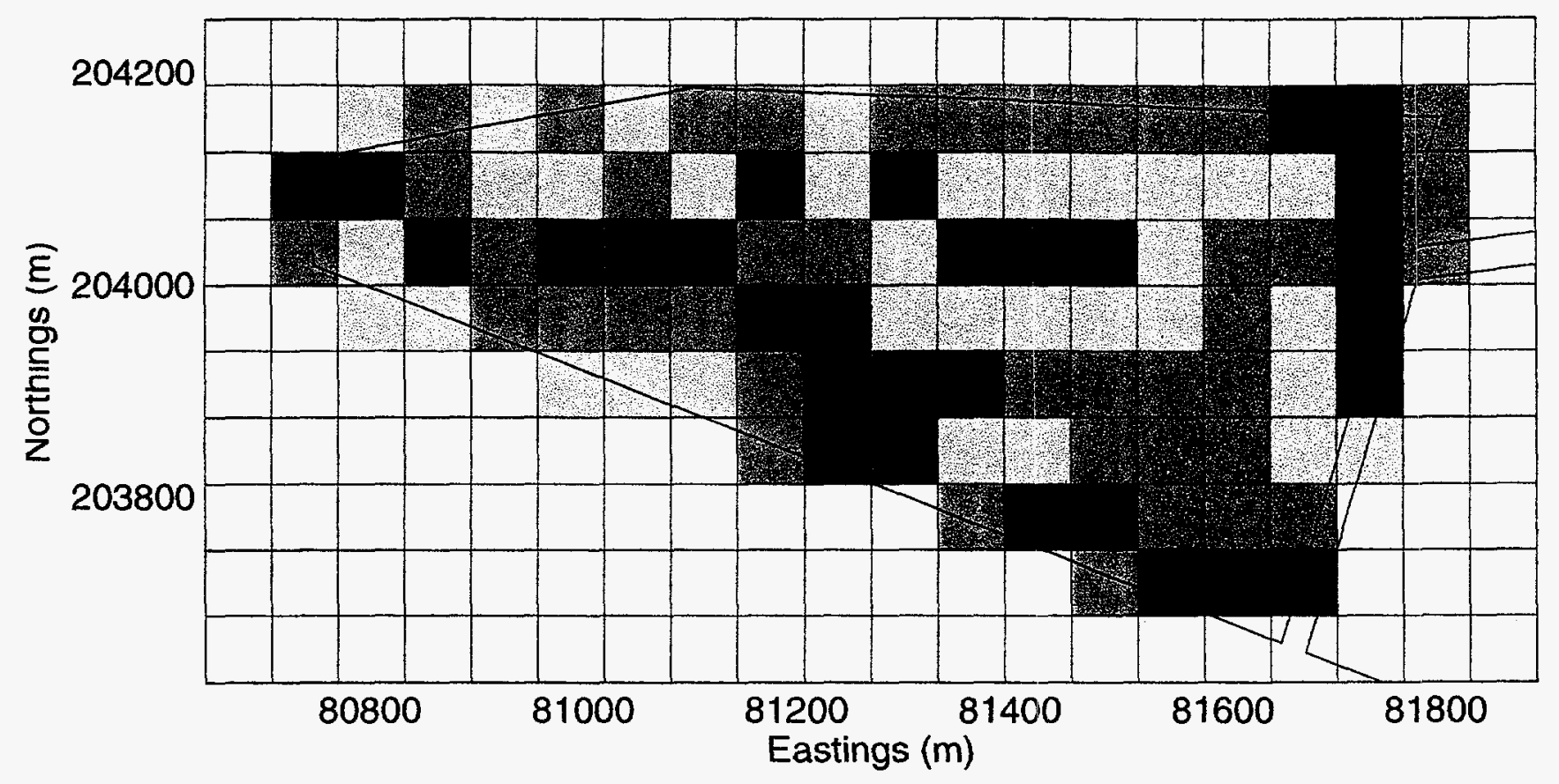

Infiltration Rate Distribution

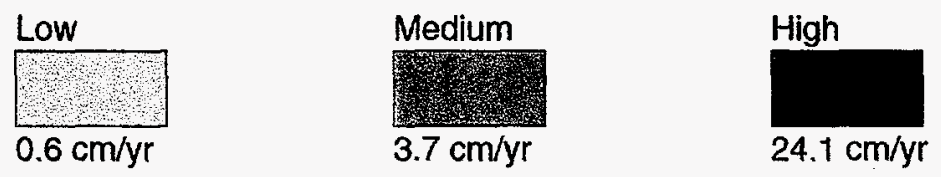

Figure 4-4. Assignment of variable surface infiltration inside the SDA. 
Time-dependent mass release histories for each radionuclide from the source term model (Section 4.1.1) were input spatially into the subsurface transport model (Figure 4-1). The source release terms were also distributed vertically at each location beginning from a depth of $1.5 \mathrm{~m}(5 \mathrm{ft})$ down to the bottom of the surficial sediments. The $1.5 \mathrm{~m}(5 \mathrm{ft})$ depth was used to represent clean overburden above the waste. The depth to the bottom of the surficial sediments varied spatially and ranged from 3.0 to $6.25 \mathrm{~m}$ (10 to $20 \mathrm{ft}$ ) below land surface except where the active low-level waste pit was excavated into the upper basalt to a

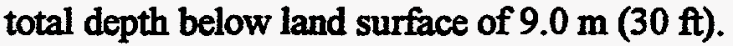

To improve representativeness, water and contaminant movement within the fractured basalts of the vadose zone were also simulated. A hydraulic description of the water movement in fractured basalt was based on the inverse modeling study (Magnuson 1995) of the large-scale infiltration test (LSIT) conducted near the SDA (Wood and Norrell 1996). Simulation of flow in both the basalt and sediments allows the model to capture horizontal spreading of the water and contaminants in the vadose zone. Previous modeling efforts related to migration of waste at the SDA, including the RWMC LLW Radiological PA (Maheras et al., 1994), conservatively assume instantaneous movement of water and dissolved contaminants through the fractured basalt portions of the vadose zone

Both the vadose zone and the aquifer regions were included in a single simulation domain. Combining the vadose zone and aquifer portions of the subsurface within a single domain eliminated the need for a numerical interface between separate vadose zone and aquifer models that would impose artificial numerical constraints between the two domains due to partitioning of gaseous phase contaminants from the vadose zone into the aquifer. Aquifer boundary heads were interpolated from the measured 1994 water levels and were assumed to be representative of long-term steady-state conditions.

4.1.2.4 Subsurface Model Calibration. The adequacy of the calibration obtained in the subsurface modeling was variable. The amount of data available for calibrating the vadose zone flow model was limited. While the model results mimicked the character of the vadose zone data, there was only a partial agreement between the simulated and limited observed results. Computational limitations in the amount of discretization that could be incorporated and adequacy of the surface infiltration description were identified as two possible reasons for only achieving a limited calibration. The calibration of the simulated water levels to measured 1994 aquifer water levels showed good agreement.

Calibration of dissolved-phase transport assumes that there was a contribution from SDA wastes to observed nitrate concentrations in the aquifer downgradient from the SDA. There were no nitrate sampling data available from the few perched water samples in the vadose zone beneath the SDA. There was, however, an indication of slightly increased nitrate concentrations downgradient from the SDA (Burgess 1996; Orr and Cecil 1991). An estimated local background concentration of $700 \mu g-N / L$ (Burgess 1996) was assumed to be correct. The dissolved-phase transport model was then calibrated to that portion of the observed aquifer nitrate concentrations above the estimated local background concentration. Since the identification of a nitrate source from the SDA is questionable, assuming that a nitrate source did cause the observed concentrations above a local background is conservative from the standpoint of assessing dissolved-phase transport. If there is in fact not a nitrate contribution to the aquifer from the SDA and the calibrated model shows there is, the model then predicts more rapid transport than is actually occurring which is generally conservative. The calibration to nitrate concentrations above the local background did show reasonable agreement. Further comparisons of the vadose zone field data and the C-14 simulations indicate that the model is predicting C-14 transport at a higher rate than is observed.

The combined gaseous- and aqueous-phase transport model was calibrated using carbon tetrachloride concentrations measured in an extensive vapor-phase monitoring network and in the 
groundwater. This calibration was very successful in that good agreement was obtained between vadose zone soil gas concentration profiles and time histories. Good agreement was also obtained between simulation and observed aquifer carbon tetrachloride concentrations in the aquifer.

\subsubsection{Predictive Simulations}

Following the flow and transport calibration effort, the model was used to predict contaminant fate and transport. Becker et al. (1998) simulated 53 total contaminants (radiological and nonradiological) with upper-bound inventory estimates. Based on the subsurface pathway flow and transport model, six radionuclides (C-14, Tc-99, I-129, Np-237, U-234, and U-238) were identified in the IRA as the primary radiological risk drivers. These six radionuclides and the necessary parents ( $\mathrm{Pu}-242, \mathrm{Pu}-238$, and Am-241) were resimulated for the Composite Analysis with best-estimate waste disposal inventories. Improved estimates of the Tc-99 inventory later showed that Tc-99 is not a primary radiological risk driver. The remainder of the radionuclides identified in the Composite Analysis were evaluated using the results from Becker et al., (1998) with appropriate inventory scaling factors applied (see Section 4.1.5). Tritium was the one radiological contaminant evaluated using the combined dissolved- and gaseous-phase transport model. All other radionuclides, including C-14, were evaluated with the dissolved-phase transport model.

Predicted model concentrations at a depth of $12 \mathrm{~m}$ ( $40 \mathrm{ft})$ within the saturated portion of the simulation domain that corresponded to the SRPA were used to calculate doses. There were effectively seven [ $8 \mathrm{~m}(26 \mathrm{ft})$ thick] vertical saturated grid blocks representing the aquifer in the flow and transport

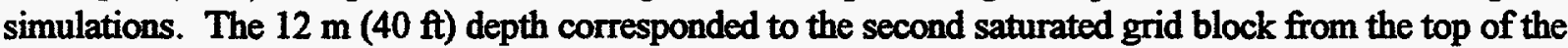
aquifer which extended from 8 to $16 \mathrm{~m}$ ( 26 to $52 \mathrm{ft}$ ). The existing monitoring wells at the SDA are generally screened in this same interval because it was the first productive zone encountered during drilling. It is assumed that this same vertical interval will supply the majority of water for a hypothetical groundwater well. During institutional control (until 2120), maximum simulated concentrations along the southern INEEL boundary were used. After institutional control, the maximum simulated concentration at the $12 \mathrm{~m}(40 \mathrm{ft})$ depth from a set of grid points approximately $100 \mathrm{~m}(328 \mathrm{ft})$ downgradient from the SDA boundary (see Figure 4-5) was used.

\subsubsection{Composite Analysis Model}

The Composite Analysis uses best-estimates of the waste inventory where the RWMC WAG 7 IRA used upper-bound estimates of the waste inventory in the risk assessment model (Becker et al., 1998). For radionuclides other than the primary risk driver, instead of redoing the entire set of simulations using the best-estimate inventory for the Composite Analysis, the IRA results were scaled based on inventory ratios. Scaling is appropriate because the uncertainty for each radionuclide is the same across waste streams and across years. All waste stream and yearly disposal information is scaled by the same factor, resulting in the total release from the waste scaling the same as well. For radionuclides that are not members of decay chains the scale factor is simply the ratio of upper-bound estimate of waste inventory to best-estimate of waste inventory. However, the scale factor for the daughter products in a decay chain depends on the relative contribution from the ingrowth compared to the initial disposal of the daughter. As such, the factor is a function of time as the relative contribution from the ingrowth increases. For this analysis, a single scale factor was used. The factor is the weighted average contribution from the initial disposals and from the ingrowth at the time of the peak groundwater risk for each daughter product. For example, the factor for $\mathrm{Np}-237$ is 0.419 . This is the weighted average of the contribution from the initial disposal of $1.8 \mathrm{Ci}$ of $\mathrm{Np}-237$ and the ingrowth of $26 \mathrm{Ci}$ from Am-241 at the time of the peak risk for Np-237. Table 4-5 presents the scale factors used and Table 4-6 presents the weighting factors used to develop the scaling factors for the daughter products. 


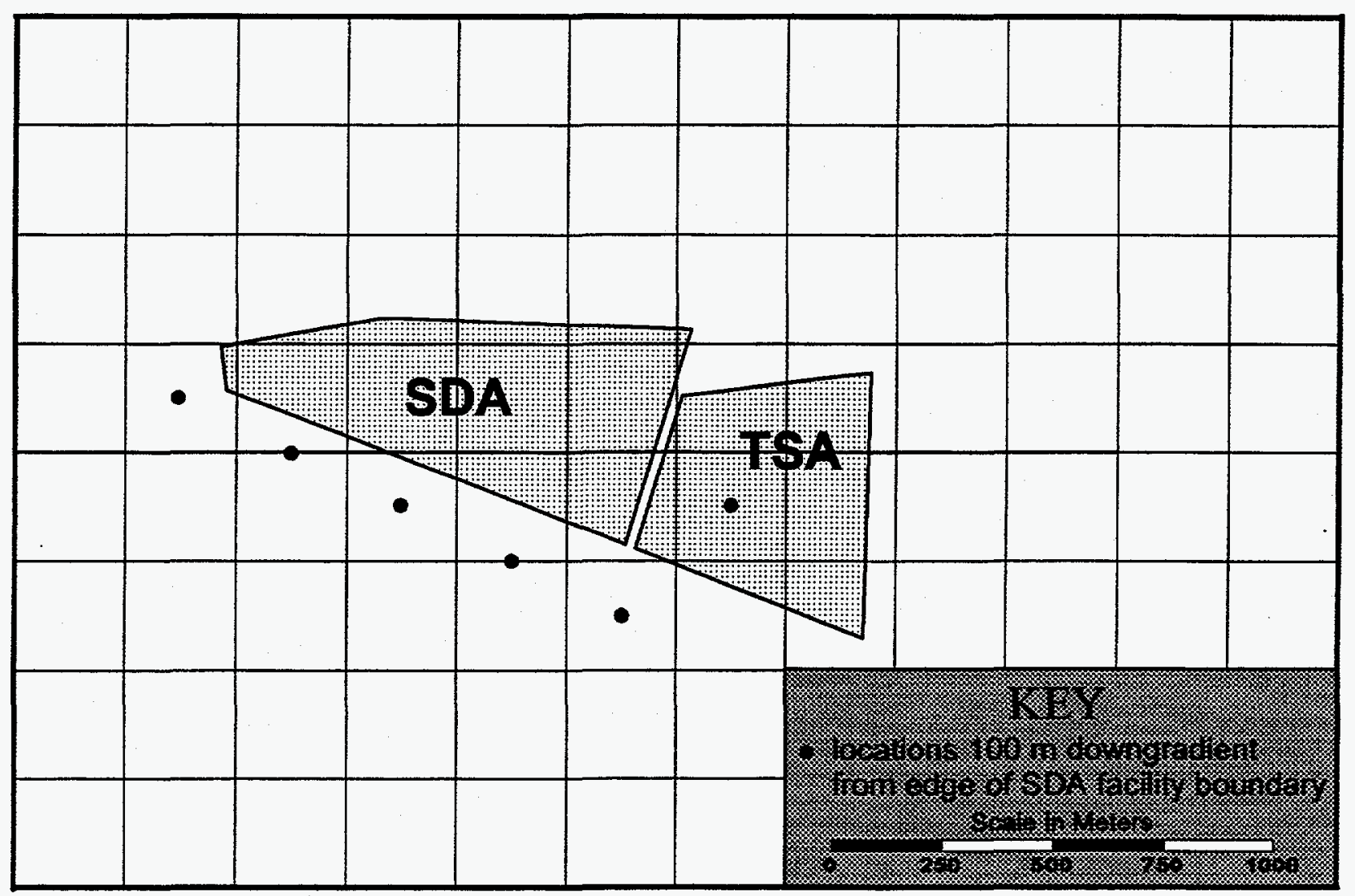

Figure 4-5. Numerical grid locations from which the peak aquifer concentrations were taken after the period of institutional control. 
Table 4-5. Scale factors used to convert the upper-bound doses to bestestimate doses.

\begin{tabular}{|c|c|c|c|}
\hline Radionuclide & $\begin{array}{c}\text { Best-Estimate Disposal Amount } \\
\text { (1952-2020) } \\
\text { (Ci) }\end{array}$ & $\begin{array}{c}\text { Upper-Bound Disposal Amount } \\
\text { (1952-1993) } \\
\text { (Ci) }\end{array}$ & $\begin{array}{c}\text { Scale Factor } \\
\text { (Best-Estimate/ Upper-Bound) }\end{array}$ \\
\hline Ac227 & $0.0000 \mathrm{E}+00$ & $0.0000 \mathrm{E}+00$ & $5.44 E-01^{*}$ \\
\hline Am241 & $1.4718 \mathrm{E}+05$ & $3.6797 E+05$ & $4.32 \mathrm{E}-01$ * \\
\hline Am243 & $2.2737 \mathrm{E}-01$ & $1.6529 \mathrm{E}+00$ & $1.38 \mathrm{E}-01$ \\
\hline $\mathrm{C14}$ & $1.2872 E+04$ & $8.8598 E+04$ & $1.45 \mathrm{E}-01^{b}$ \\
\hline $\mathrm{Cl} 36$ & $3.1420 \mathrm{E}-01$ & $2.2887 E+00$ & $1.37 \mathrm{E}-01$ \\
\hline Cm244 & $7.0638 \mathrm{E}+01$ & $4.9733 E+02$ & $1.42 \mathrm{E}-01$ \\
\hline Co60 & $6.0057 \mathrm{E}+06$ & $9.3854 \mathrm{E}+06$ & $6.40 \mathrm{E}-01$ \\
\hline Cs137 & $6.2116 \mathrm{E}+05$ & $1.6701 E+06$ & $3.72 \mathrm{E}-01$ \\
\hline Eu152 & $2.4239 \mathrm{E}+02$ & $3.1877 \mathrm{E}+02$ & $7.60 \mathrm{E}-01$ \\
\hline Eu1s4 & $2.9570 \mathrm{E}+03$ & $2.0746 E+0.4$ & $1.43 \mathrm{E}-01$ \\
\hline H3 & $7.1794 \mathrm{E}+06$ & $3.8012 E+06$ & $1.89 \mathrm{E}+00$ \\
\hline 1129 & $1.9950 \mathrm{E}-01$ & $4.5886 \mathrm{E}-01$ & $4.35 \mathrm{E}-01$ \\
\hline $\mathrm{Na} 22$ & $1.0919 \mathrm{E}+00$ & $6.0624 E+00$ & $1.80 \mathrm{E}-01$ \\
\hline Nb94 & $5.2689 \mathrm{E}+01$ & $9.1317 \mathrm{E}+01$ & $5.77 \mathrm{E}-01$ \\
\hline Ni59 & $6.4952 E+03$ & $3.6314 \mathrm{E}+04$ & 1.79E-01 \\
\hline Ni63 & $1.2644 \mathrm{E}+06$ & $2.2433 E+06$ & $5.64 \mathrm{E}-01$ \\
\hline Np237 & $1.8422 \mathrm{E}+00$ & $1.3081 E+01$ & $4.19 \mathrm{E}-01^{2}$ \\
\hline $\mathrm{Pa} 231$ & $0.0000 \mathrm{E}+00$ & $0.0000 E+00$ & $5.44 \mathrm{E}-01^{\circ}$ \\
\hline $\mathrm{Pb} 210$ & $0.0000 \mathrm{E}+\infty 0$ & $0.0000 \mathrm{E}+00$ & $6.76 \mathrm{E}-01^{2}$ \\
\hline Pu238 & $2.4509 E+03$ & $9.8517 E+03$ & $2.49 \mathrm{E}-01$ \\
\hline Pu239 & $6.3594 E+04$ & $1.5999 \mathrm{E}+05$ & $3.97 \mathrm{E}-01^{2}$ \\
\hline Pu240 & $1.4581 \mathrm{E}+04$ & $4.0257 \mathrm{E}+04$ & $3.62 \mathrm{E}-01^{*}$ \\
\hline Pu241 & $3.8665 \mathrm{E}+05$ & $9.8360 \mathrm{E}+05$ & 3.93E-01 \\
\hline Pu242 & $9.6116 \mathrm{E}-01$ & $2.3392 \mathrm{E}+00$ & $4.11 E-01$ \\
\hline $\mathrm{Ra} 226$ & $5.9887 E+01$ & $8.8604 \mathrm{E}+01$ & 6.75E-01 2 \\
\hline $\mathbf{R a 2 2 8}$ & $0.0000 \mathrm{E}+00$ & $0.0000 \mathrm{E}+00$ & $6.55 \mathrm{E}-01^{2}$ \\
\hline$S+90$ & $4.5221 E+05$ & $2.6564 E+06$ & $1.70 E-01$ \\
\hline Tc99 & $1.8875 E+02$ & $1.3289 \mathrm{E}+03$ & $1.42 \mathrm{E}-01$ \\
\hline Th228 & $1.0200 \mathrm{E}+01$ & $1.5563 \mathrm{E}+01$ & $6.55 \mathrm{E}-01^{*}$ \\
\hline Th229 & $0.0000 \mathrm{E}+00$ & $0.0000 \mathrm{E}+00$ & $7.29 \mathrm{E}-01^{*}$ \\
\hline Th230 & $1.7890 \mathrm{E}-02$ & $2.8399 \mathrm{E}-02$ & 4.43E-01* \\
\hline Th232 & $1.3187 \mathrm{E}+00$ & $1.7963 E+00$ & $7.34 \mathrm{E}-01^{2}$ \\
\hline U232 & $1.0582 E+01$ & $1.3677 E+01$ & $7.74 E-01$ \\
\hline U233 & $1.1499 \mathrm{E}+00$ & $1.5775 \mathrm{E}+00$ & 3.65E-01 * \\
\hline U234 & $7.1766 \mathrm{E}+01$ & $1.6233 E+02$ & $4.41 \mathrm{E}-01^{*}$ \\
\hline U235 & $5.7167 \mathrm{E}+00$ & $1.0516 \mathrm{E}+01$ & $5.40 \mathrm{E}-01^{*}$ \\
\hline U236 & $2.1586 \mathrm{E}+00$ & $6.2100 \mathrm{E}+00$ & $3.59 \mathrm{E}-01^{*}$ \\
\hline U238 & $1.5815 E+02$ & $4.3387 \mathrm{E}+02$ & $3.65 \mathrm{E}-01^{*}$ \\
\hline
\end{tabular}


Table 4-6. Scale factor for daughter products.

\begin{tabular}{|c|c|c|c|c|c|c|c|c|c|}
\hline Nuclide & $\begin{array}{c}\text { Initial } \\
\text { Inventory } \\
\text { (Ci) }\end{array}$ & $\begin{array}{l}\text { Time of Peak } \\
\text { Groundwater } \\
\text { Concentration }\end{array}$ & $\begin{array}{c}\text { Daughter } \\
\text { Half Life } \\
\text { (yrs) }\end{array}$ & $\begin{array}{c}\text { Inventory at } \\
\text { Peak } \\
\text { Concentratio } \\
n(\mathrm{Ci})\end{array}$ & Parent & $\begin{array}{l}\text { Parent } \\
\text { Initial } \\
\text { Inventory } \\
\text { (Ci) }\end{array}$ & $\begin{array}{c}\text { Parent } \\
\text { Half Life } \\
\text { (yrs) }\end{array}$ & $\begin{array}{l}\text { Inventory } \\
\text { of } \\
\text { Daughter } \\
\text { at Peak w/ } \\
\text { Decay } \\
\text { (Ci) }\end{array}$ & $\begin{array}{l}\text { Weighted } \\
\text { Average } \\
\text { scale Factor }\end{array}$ \\
\hline Ac227 & $0.00 \mathrm{E}+00$ & $5.76 E+03$ & $2.18 \mathrm{E}+01$ & $0.00 \mathrm{E}+00$ & $\mathrm{~Pa} 231$ & $0.00 \mathrm{E}+00$ & $3.73 E+04$ & $0.00 \mathrm{E}+00$ & $5.44 E-01$ \\
\hline Am241 & $1.60 \mathrm{E}+05$ & $3.75 E+03$ & $4.32 E+02$ & $8.90 \mathrm{E}+03$ & Pu241 & $3.87 \mathrm{E}+05$ & $1.44 \mathrm{E}+01$ & $7.43 E+02$ & $4.32 \mathrm{E}-01$ \\
\hline Np237 & $1.84 \mathrm{E}+00$ & $5.76 \mathrm{E}+03$ & $2.14 E+06$ & $1.84 \mathrm{E}+00$ & Am241 & $1.60 \mathrm{E}+05$ & $4.32 E+02$ & $3.22 E+01$ & 4.19E-01 \\
\hline $\mathrm{Pa231}$ & $0.00 \mathrm{E}+00$ & $5.76 \mathrm{E}+03$ & $3.73 E+04$ & $0.00 \mathrm{E}+00$ & U235 & $5.72 \mathrm{E}+00$ & $7.04 \mathrm{E}+08$ & 4.42E-01 & $5.44 \mathrm{E}-01$ \\
\hline $\mathrm{Pb} 210$ & $0.00 \mathrm{E}+00$ & $1.20 \mathrm{E}+04$ & $2.23 \mathrm{E}+01$ & $0.00 \mathrm{E}+00$ & Ra226 & $5.99 \mathrm{E}+01$ & $1.60 \mathrm{E}+03$ & $7.64 \mathrm{E}-01$ & $6.76 \mathrm{E}-01$ \\
\hline Pu239 & $6.36 \mathrm{E}+04$ & $1.20 \mathrm{E}+04$ & $2.41 \mathrm{E}+04$ & $4.76 \mathrm{E}+04$ & Am243 & $2.27 \mathrm{E}-01$ & $7.38 E+03$ & $3.62 \mathrm{E}-02$ & $3.97 \mathrm{E}-01$ \\
\hline $\mathrm{Pu} 240$ & $1.46 \mathrm{E}+04$ & $1.20 \mathrm{E}+04$ & $6.57 \mathrm{E}+03$ & $5.05 E+03$ & Cm244 & $7.06 \mathrm{E}+01$ & $1.81 \mathrm{E}+01$ & $6.72 \mathrm{E}-02$ & $3.62 \mathrm{E}-01$ \\
\hline $\mathrm{Ra226}$ & $5.99 \mathrm{E}+01$ & $1.20 \mathrm{E}+04$ & $1.60 \mathrm{E}+03$ & $7.68 \mathrm{E}-01$ & Th230 & 1.79E-02 & $7.70 E+04$ & $1.65 \mathrm{E}-02$ & $6.75 \mathrm{E}-01$ \\
\hline $\operatorname{Ra} 228$ & $0.00 \mathrm{E}+00$ & $1.20 \mathrm{E}+04$ & $5.75 \mathrm{E}+00$ & $0.00 \mathrm{E}+00$ & Th232 & $1.32 \mathrm{E}+00$ & $1.41 \mathrm{E}+10$ & $1.32 \mathrm{E}+00$ & $6.55 \mathrm{E}-01$ \\
\hline Th229 & $0.00 \mathrm{E}+00$ & $8.96 E+03$ & $7.34 \mathrm{E}+03$ & $0.00 \mathrm{E}+00$ & U233 & $1.15 \mathrm{E}+00$ & $1.59 \mathrm{E}+05$ & $5.47 \mathrm{E}-01$ & $7.29 \mathrm{E}-01$ \\
\hline Th230 & $1.79 \mathrm{E}-02$ & $8.56 \mathrm{E}+03$ & $7.70 \mathrm{E}+04$ & $1.69 \mathrm{E}-02$ & U234 & $7.18 \mathrm{E}+01$ & $2.45 E+05$ & $4.11 E+00$ & 4.43E-01 \\
\hline Th232 & $1.32 \mathrm{E}+00$ & $1.20 \mathrm{E}+04$ & $1.41 \mathrm{E}+10$ & $1.32 \mathrm{E}+00$ & U236 & $2.16 \mathrm{E}+00$ & $2.34 \mathrm{E}+07$ & $1.07 \mathrm{E}-06$ & $7.34 \mathrm{E}-01$ \\
\hline U233 & $1.15 \mathrm{E}+00$ & $5.36 \mathrm{E}+03$ & $1.59 \mathrm{E}+05$ & $1.13 \mathrm{E}+00$ & Np237 & $1.84 \mathrm{E}+00$ & $2.14 \mathrm{E}+06$ & $1.84 \mathrm{E}+00$ & $3.65 \mathrm{E}-01$ \\
\hline U234 & $7.18 E+01$ & $4.35 E+03$ & $2.45 E+05$ & $7.13 E+01$ & U238 & $1.58 \mathrm{E}+02$ & 4.47E+09 & $1.07 E+00$ & 4.41E-01 \\
\hline U235 & $5.72 \mathrm{E}+00$ & 4.55E+03 & $7.04 \mathrm{E}+08$ & $5.72 \mathrm{E}+00$ & Pu239 & $6.36 \mathrm{E}+04$ & $2.41 \mathrm{E}+04$ & $1.57 \mathrm{E}-01$ & $5.40 \mathrm{E}-01$ \\
\hline U236 & $2.16 \mathrm{E}+00$ & $4.76 \mathrm{E}+03$ & $2.34 E+07$ & $2.16 \mathrm{E}+00$ & Pu240 & $1.46 \mathrm{E}+04$ & $6.57 E+03$ & $7.17 \mathrm{E}+00$ & $3.59 \mathrm{E}-01$ \\
\hline U238 & $1.58 \mathrm{E}+02$ & $4.55 \mathrm{E}+03$ & 4.47E+09 & $1.58 \mathrm{E}+02$ & $\mathrm{Pu} 242$ & $9.61 \mathrm{E}-01$ & $3.76 \mathrm{E}+05$ & 3.87E-07 & $3.65 \mathrm{E}-01$ \\
\hline
\end{tabular}


In order to check the scaling assumptions, Am-241 and Tc-99 were also rerun. Figure 4-6 and Figure 4-7 show a comparison of the scaled IRA doses used in the Composite Analysis with the doses run using the best-estimate waste disposal inventory. As can be seen, the results match well and the scaling is appropriate. Note that the significant drop in the dose around the year 7780 is a result of the termination of the C-14 simulations earlier than the other long-term dose contributors.

\subsection{Exposure Scenarios}

The all-pathways exposure scenarios resulting from contaminated groundwater are evaluated in the Composite Analysis. Receptors (members of the public) are assumed to be located at the INEEL Site boundary during operations and institutional control (until the year 2120) and at $100 \mathrm{~m}$ from the RWMC boundary during post-institutional control. Potential radiological dose to a hypothetical future member of the public from the active LLW disposal facility and all other sources of radioactive material in the ground that may interact with the LLW disposal facility are assessed. Based upon the source term development in Section 3.1, the RWMC (WAG 7) is the only source at the INEEL that will significantly interact with the LLW facility.

The potential dose from gas-phase radionuclides in the air pathway is negligible and is not evaluated in the CA. The INEEL demonstrates compliance with annual dose limits for the public caused by air emissions, as specified in 40 CFR 61, Subpart H National Emission Standards for Emissions of Radionuclides other than Radon from Department of Energy Facilities (NESHAP). From 1991 to 1996, the annual off-Site doses caused by INEEL's operations (as reported in the NESHAP annual report series, DOE/ID-10342 years 1991 through 1996), have ranged from 0.0015 to $0.031 \mathrm{mrem}$. These doses are much less than $1 \%$ of the $10 \mathrm{mrem} / \mathrm{yr}$ standard. Future trends in dose estimates along atmospheric pathways caused by point source emissions will depend on Site operations, but are expected to be relatively constant for the foreseeable future. Doses caused by diffuse emissions are expected to decrease over the long term as remedial actions are completed or inventories are depleted.

Figure 4-8 summarizes the exposure pathways evaluated for the CA. The following sections describe the all-pathways and groundwater protection scenarios used to evaluate potential adverse health effects to members of the public.

\subsubsection{All-Pathways}

The methodology used to calculate the all-pathways dose is based on the methodology presented in NRC (1977) and Peterson (1983). This all-pathways scenario assumes a receptor consumes: (1) contaminated groundwater, (2) leafy vegetables and produce that were irrigated with contaminated groundwater, and (3) milk and meat from animals that consume contaminated water and pasture grass irrigated with contaminated groundwater. Radionuclide concentrations as a function of time at the receptor well, which are calculated using the hydrological transport model described in Section 4.1, are used as input to this model. The receptor is located at the INEEL Site boundary during the operational and institutional control periods, based on guidance from DOE-HQ. ${ }^{1}$ During this time, the INEEL Site boundary is maintained, and access by the public is not allowed. During post-institutional control, the

1. Letter from S. P. Cowan to J. T. Case, June 20, 1996, "Groundwater Compliance for the Low-Level Waste Radiological Performance Assessment for the Radioactive Waste Management Complex at the Idaho National Engineering Laboratory." 


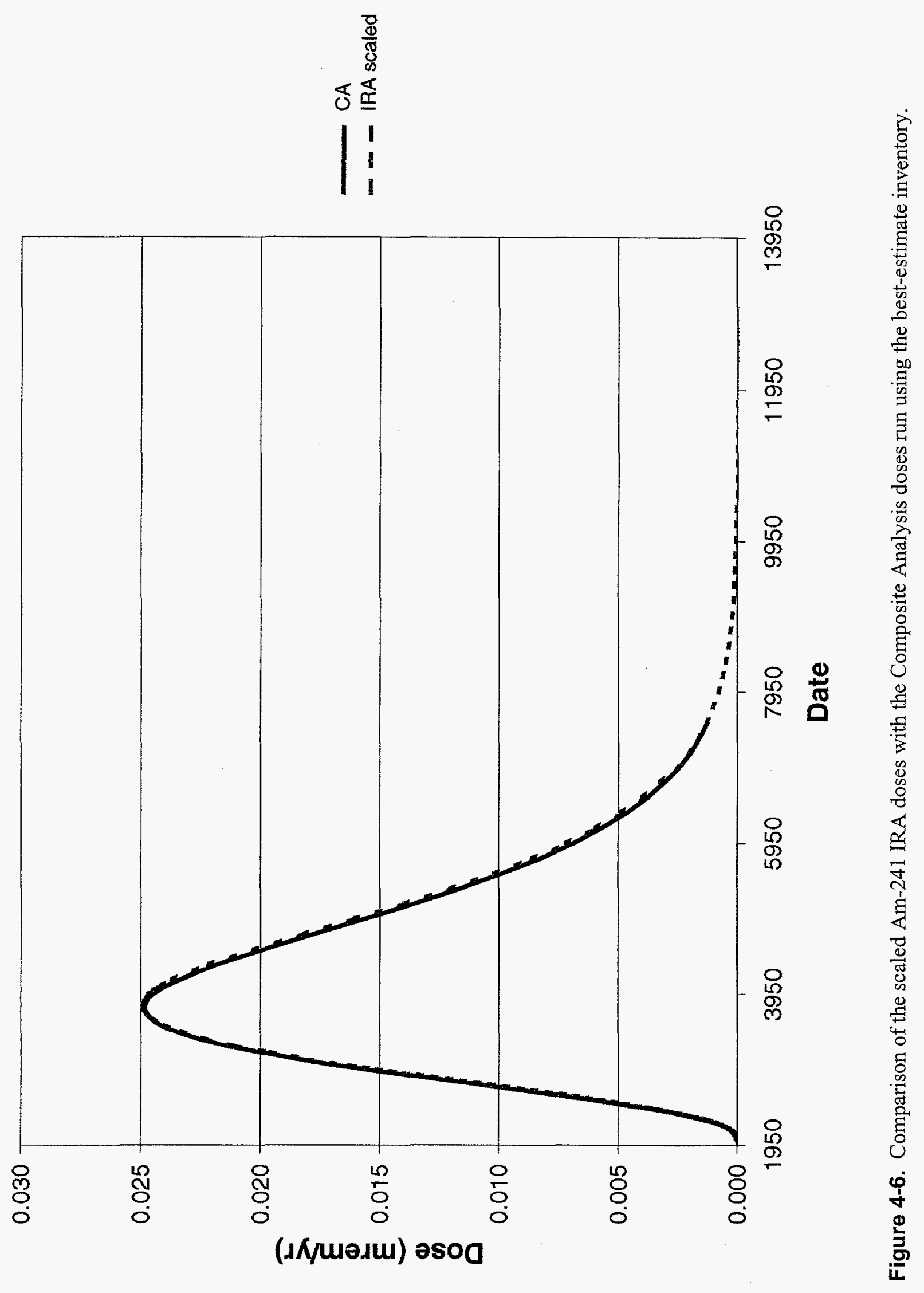


$0 z-t$

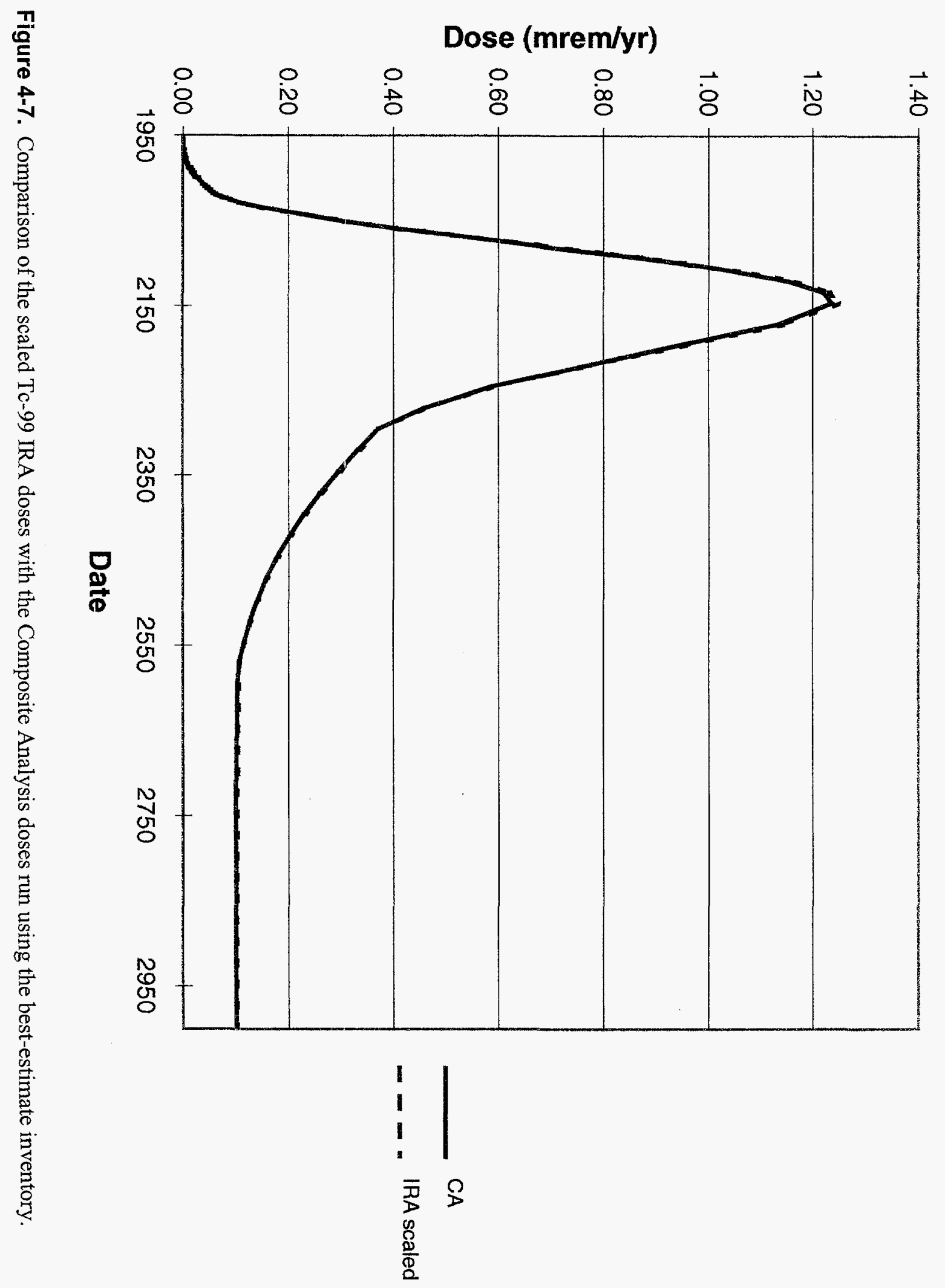




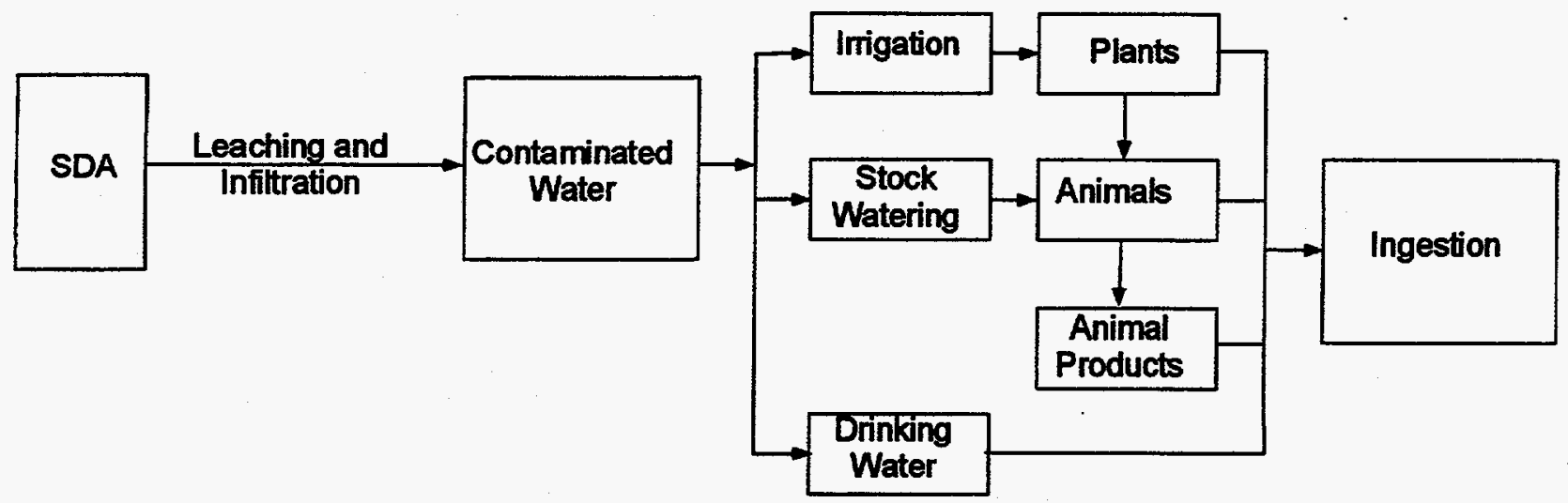

Figure 4-8. Exposure pathways at the RWMC considered in the Composite Analysis.

receptor is located $100 \mathrm{~m}$ downgradient of the RWMC facility boundary. Table 4-7 contains the parameter values used in the all pathways dose calculation.

The dose from human consumption of drinking water is calculated using:

$D=C_{G W} \times U_{W} \times D C F \times \frac{10^{-6} \mu C i}{p C i} \times \frac{1,000 \mathrm{mrem}}{\text { rem }}$

where

$\mathrm{D}=$ dose (CEDE) from one year's consumption of contaminated media, in this case groundwater (mrem/yr)

$\mathrm{C}_{\mathrm{GW}}=$ radionuclide concentration in groundwater $(\mathrm{pCi} / \mathrm{L})$

$\mathrm{U}_{\mathrm{w}} \quad=\quad$ human consumption rate of water $(\mathrm{L} / \mathrm{yr})$

$\mathrm{DCF}=$ ingestion dose conversion factor $(\mathrm{rem} / \mu \mathrm{Ci})$.

The beef and dairy exposure route assumes cattle drink contaminated stock water and the receptor in turn consumes the contaminated beef and milk from the cattle. Meat and milk are treated separately. The dose is calculated using:

Meat:

$D=C_{G W} \times Q_{W} \times F_{f} \times U_{B} \times D C F \times \frac{10^{-6} \mu C i}{p C i} \times \frac{1,000 \mathrm{mrem}}{\text { rem }} \times F B$ 
Table 4-7. Parameter values used in the all-pathways dose calculation.

\begin{tabular}{|c|c|c|}
\hline Parameter & Value & Reference \\
\hline $\mathrm{U}_{\mathrm{W}}$ & 2 L/day & EPA (1989a) \\
\hline$Q_{w}$ (beef cattle) & $50 \mathrm{~L} /$ day & NRC (1977) \\
\hline$Q_{w}$ (milk cattle) & $60 \mathrm{~L} /$ day & NRC (1977) \\
\hline$Q_{k}$ (beef cattle, dry weight) & $12 \mathrm{~kg} /$ day & NCRP (1984) \\
\hline $\mathrm{Q}_{F}$ (milk cattle, dry weight) & $16 \mathrm{~kg} /$ day & NCRP (1984) \\
\hline $\mathrm{U}_{\mathrm{B}}$ & $85 \mathrm{~kg} / \mathrm{yr}$ & Rupp (1980) \\
\hline $\mathrm{U}_{\mathrm{M}}$ & $112 \mathrm{~L} / \mathrm{yr}$ & Rupp (1980) \\
\hline $\mathrm{U}_{\mathrm{P}}$ & $176 \mathrm{~kg} / \mathrm{yr}$ & Rupp (1980) \\
\hline $\mathrm{U}_{\mathrm{LV}}$ & $18 \mathrm{~kg} / \mathrm{yr}$ & Rupp (1980) \\
\hline I & $8.47 \mathrm{~L} / \mathrm{m}^{2}$ day & Site specific \\
\hline $\mathrm{K}$ & $0.025 \mathrm{~mm}^{-1}$ & Peterson (1983) \\
\hline $\mathrm{r} / Y_{\mathrm{v}}$ (leafy veg, wet weight) & $0.076 \mathrm{~m}^{2} / \mathrm{kg}$ & $\begin{array}{l}\text { Calculated from Baes and Orton (1979) and Baes } \\
\text { et al. (1984) }\end{array}$ \\
\hline $\mathrm{r} / \mathrm{Y}_{\mathrm{v}}$ (produce, wet weight) & $0.032 \mathrm{~m}^{2} / \mathrm{kg}$ & $\begin{array}{l}\text { Calculated from Baes and Orton (1979) and Baes } \\
\text { et al. (1984) }\end{array}$ \\
\hline $\mathrm{r} / Y_{\mathrm{v}}$ (pasture, dry weight) & $2.0 \mathrm{~m}^{2} / \mathrm{kg}$ & $\begin{array}{l}\text { Calculated from Baes and Orton (1979) and Baes } \\
\text { et al. (1984) }\end{array}$ \\
\hline P (dry weight) & $225 \mathrm{~kg} / \mathrm{m}^{2}$ & DOE (1987) \\
\hline t & 90 day & Site specific \\
\hline$t_{b}$ & 365 day & Site specific \\
\hline $\mathbf{f}_{\mathrm{I}}$ & 0.25 & Site specific \\
\hline $\mathrm{T}$ (leafy veg) & 1.0 & Ng et al. (1978) \\
\hline$T$ (produce) & 0.1 & Ng et al. (1978) \\
\hline DF (leafy veg) & 0.5 & Ng et al. (1978) \\
\hline DF (produce) & 1.0 & Ng et al. (1978) \\
\hline FV & 0.7 & EPA (1989b) \\
\hline FB & 0.442 & EPA (1989b) \\
\hline FM & 0.399 & EPA (1989b) \\
\hline
\end{tabular}


Milk:

$$
D=C_{G W} \times Q_{W} \times F_{m} \times U_{M} \times D C F \times \frac{10^{-6} \mu C i}{p C i} \times \frac{1,000 \mathrm{mrem}}{\mathrm{rem}} \times F M
$$

where

$\mathrm{Q}_{\mathrm{w}} \quad=\quad$ consumption rate of water by beef or milk cattle ( $\mathrm{L} /$ day)

$\mathrm{F}_{\mathrm{f}} \quad=\quad$ meat transfer coefficient (day $\left./ \mathrm{kg}\right)$

$\mathrm{U}_{\mathrm{B}}=$ human consumption rate of meat $(\mathrm{kg} / \mathrm{yr})$

FB = fraction of beef produced locally (unitless)

$F_{m} \quad=\quad$ milk transfer coefficient $($ day $/ \mathrm{L})$

$\mathrm{U}_{\mathrm{M}} \quad=\quad$ human consumption rate of milk $(\mathrm{L} / \mathrm{yr})$

FM = fraction of milk produced locally (unitless).

The dose to humans from ingestion of contaminated leafy vegetables and produce is calculated assuming two contamination routes: (1) direct deposition of contaminated irrigation water on plants and (2) deposition of contaminated irrigation water on soil followed by root uptake by plants. Leafy vegetables and produce are treated separately. The dose through direct deposition is calculated using:

Leafy Vegetables - Direct Deposition:

$$
D=\frac{C_{G W} \times I \times r}{Y_{v}} \times \frac{1-e^{-\left(\lambda_{r}+K I\right) \epsilon_{i}}}{\lambda_{r}+k I} \times U_{L V} \times \frac{10^{-6} \mu C i}{p C i} \times D C F \times \frac{1,000 \mathrm{mrem}}{\mathrm{rem}} \times D F \times T \times F V
$$

Produce - Direct Deposition:

$$
D=\frac{C_{G W} \times I \times r}{Y_{\nu}} \times \frac{1-e^{-\left(\lambda_{r}+k\right) t_{i}}}{\lambda_{r}+k I} \times U_{P} \times \frac{10^{-6} \mu C i}{p C i} \times D C F \times \frac{1,000 \mathrm{mrem}}{r e m} \times D F \times T \times F V
$$

where

I = irrigation rate $\left(\mathrm{L} / \mathrm{m}^{2}\right.$-day $)$

$r=$ interception fraction (unitless)

$Y_{v}=$ agricultural yield $\left(\mathrm{kg} / \mathrm{m}^{2}\right.$, wet weight)

$\lambda_{\mathrm{I}}=$ radioactive decay constant (per day) 


$$
\begin{aligned}
& k=\text { washoff constant }\left(\mathrm{mm}^{-1}\right) \\
& t_{i}=\text { irrigation time (day). } \\
& U_{L V}=\text { human consumption rate of leafy vegetables }(\mathrm{kg} / \mathrm{yr}) \\
& D F=\text { fraction of activity remaining after preparation and processing (unitless) } \\
& T=\text { translocation factor (unitless) } \\
& F V=\text { fraction of leafy vegetables and produce produced locally (unitless) } \\
& U_{P}=\text { human consumption rate of produce (kg/yr). }
\end{aligned}
$$

The product kI is also known as the weathering rate constant because of washoff (Peterson 1983). This quantity describes the rate at which material is removed from plant surfaces by water and is analogous to $\lambda_{e}$, the weathering rate constant used in non-irrigation situations. The value of $\mathrm{kJ}$ is calculated using:

$$
k I=0.025 \mathrm{~mm}^{-1} \times \frac{8.47 \mathrm{~L}}{m^{2}-d a y} \times \frac{1 \mathrm{~m}^{3}}{1,000 \mathrm{~L}} \times \frac{1,000 \mathrm{~mm}}{1 \mathrm{~m}}=0.212 / \mathrm{day}
$$

The dose from deposition of contaminated irrigation water on soil followed by root uptake by plants and human consumption of plants is calculated using the following equations. Credit is not taken for leaching of radionuclides from the root zone of plants.

\section{Leafy Vegetables - Root Uptake:}

$D=\frac{C_{\mathrm{GW}} \times I \times f_{l}}{P} \times \frac{1-e^{-\lambda_{r} t_{b_{l}}}}{\lambda_{r}+k I} \times C R \times U_{L V} \times \frac{10^{-6} \mu C i}{p C i} \times D C F \times \frac{1,000 \mathrm{mrem}}{\mathrm{rem}} \times F V$

Produce - Root Uptake:

$$
D=\frac{C_{G W} \times I \times f_{l}}{P} \times \frac{1-e^{-\lambda_{2} t_{b_{l}}}}{\lambda_{r}+k I} \times C R \times U_{P} \times \frac{10^{-6} \mu C i}{p C i} \times D C F \times \frac{1,000 \mathrm{mrem}}{\mathrm{rem}} \times F V
$$

where

$$
\begin{array}{ll}
\mathbf{f}_{\mathrm{I}} & =\quad \text { fraction of the year that crops are irrigated (unitless) } \\
\mathbf{P} & =\text { areal density }\left[\mathrm{kg}\left(\mathrm{dry} \text { weight soil) } / \mathrm{m}^{2}\right]\right. \\
\mathrm{CR} & =\quad \text { concentration ratio }[\mathrm{pCi} / \mathrm{kg} \text { (wet weight plant) }+\mathrm{pCi} / \mathrm{kg} \text { (dry weight soil)] } \\
\mathrm{t}_{\mathrm{b}} & =\text { build-up time for radionuclides in soil (day). }
\end{array}
$$


The dose to humans from ingestion of contaminated animal products is also calculated assuming two contamination routes: (1) direct deposition and (2) root uptake; meat and milk are treated separately. All food (pasture or stored feed) eaten by cattle is assumed to be contaminated. The dose through direct deposition is calculated using:

Meat - Direct Deposition:

$D=\frac{C_{G W} \times I \times r}{Y_{v}} \times \frac{1-e^{-\left(\lambda_{r}+K I\right) t_{i}}}{\lambda_{r}+k I} \times Q_{F} \times F_{f} \times U_{B} \times \frac{10^{-6} \mu C i}{p C i} \times D C F \times \frac{1,000 \mathrm{mrem}}{\mathrm{rem}} \times F B$

Milk - Direct Deposition:

$D=\frac{C_{G W} \times I \times r}{Y_{v}} \times \frac{1-e^{-\left(l_{r}+K I\right) t_{i}}}{l_{r}+k I} \times Q_{F} \times F_{m} \times U_{M} \times \frac{10^{-6} m C i}{p C i} \times D C F \times \frac{1,000 \mathrm{mrem}}{\mathrm{rem}} \times F M$

where

$\mathrm{Y}_{\mathrm{v}} \quad=\quad$ agricultural yield $\left(\mathrm{kg} / \mathrm{m}^{2}\right.$, dry weight $)$

$\mathrm{Q}_{F} \quad=\quad$ animal consumption rate of pasture and feed $[\mathrm{kg}(\mathrm{dry}) /$ day $]$.

The dose through deposition on soil followed by root uptake is calculated using the following equations. As with produce and leafy vegetables, credit is not taken for leaching of radionuclides from the root zone of plants.

Meat - Root Uptake:

$D=\frac{C_{G W} \times I \times f_{i}}{P} \times \frac{1-e^{-\lambda_{r} t_{b_{i}}}}{\lambda_{r}} \times C R \times Q_{F} \times F_{f} \times U_{B} \times \frac{10^{-6} \mu C i}{p C i} \times D C F \times \frac{1,000 \mathrm{mrem}}{\mathrm{rem}} \times F B$

Milk - Root Uptake:

$D=\frac{C_{G W} \times I \times f_{i}}{P} \times \frac{1-e^{-\lambda_{r} t_{b_{i}}}}{\lambda_{r}} \times C R \times Q_{F} \times F_{m} \times U_{M} \times \frac{10^{-6} \mu C i}{p C i} \times D C F \times \frac{1,000 \mathrm{mrem}}{\mathrm{rem}} \times F M$

where

$\mathrm{CR}=$ concentration ratio $[\mathrm{pCi} / \mathrm{kg}$ (dry weight plant) $+\mathrm{pCi} / \mathrm{kg}$ (dry weight soil)]. 
Equivalent water intake rates for all pathways are calculated using the above methodology and a spreadsheet. These rates are then input into GWSCREEN to perform all-pathways dose calculations.

Secondary and indirect pathways, such as inhalation of contaminated irrigation water, inhalation of contaminated dust, or external exposure from radionuclides deposited on the soil, were omitted from this scenario. These pathways were either not viewed as credible (e.g., a farmer standing under a center pivot irrigator while it was rumning and inhaling contaminated irrigation water) or would contribute relatively minor amounts when compared to direct pathways such as direct ingestion of contaminated water.

\subsubsection{Groundwater Protection Scenario}

The groundwater protection scenario is used to evaluate compliance with the groundwater protection performance objectives. Receptor locations for this analysis were chosen based on guidance from DOE$\mathrm{HQ}^{2}$ During the operational and institutional control periods, the receptor is located at the nearest INEEL Site boundary in the direction of groundwater flow, $5,500 \mathrm{~m}(18,045 \mathrm{ft})$ south-southwest from the RWMC. During this time, the INEEL Site boundary is maintained, and access by the public is not allowed. During post-institutional control, the receptor is located $100 \mathrm{~m}(328 \mathrm{ft})$ downgradient of the RWMC facility boundary. Radionuclide concentrations as a function of time at the receptor well are calculated using the hydrological transport model described in Section 4.1, and are used as input to the groundwater protection analysis.

\subsection{Composite Analysis Results}

The results of the Composite Analysis indicate that during the 1,000 year compliance period the projected total dose to a hypothetical member of the public does not exceed the DOE primary dose limit of $100 \mathrm{mrem} / \mathrm{yr}$. The CA results predict an all-pathways dose rising to $58 \mathrm{mrem} / \mathrm{yr}$ by the year 3,000 for a member of the public located $100 \mathrm{~m}$ (328 ft) downgradient of the SDA. Within the period of institutional control, a member of the public located at the INEEL Site boundary would receive a minimal all-pathways dose of $0.23 \mathrm{mrem} / \mathrm{yr}$.

\subsubsection{Peak Dose Results}

The peak dose results for a receptor located $100 \mathrm{~m}$ (328 ft) downgradient from the SDA during the 1,000 yr compliance period are given in Table 4-10. The results include the peak groundwater ingestion dose, the peak all pathways dose, the peak groundwater concentration and the year the peak occurs. The largest predicted radionuclide doses are for C-14, Np-237, U-234, and U-238 (Table 4-8). The dose peak occurs at the end of the $1,000 \mathrm{yr}$ period of compliance with $45 \mathrm{mrem} / \mathrm{yr}$ for direct ingestion of groundwater and $58 \mathrm{mrem} / \mathrm{yr}$ for the all pathways dose (Table 4-8). During the 1,000 yr compliance period the total beta/gamma dose from groundwater ingestion peaks at approximately $10 \mathrm{mrem} / \mathrm{yr}$ at the year 2245 and exceeds the maximum contaminant level (MCL) of $4 \mathrm{mrem} / \mathrm{yr}$ (Table 4-8). The total alpha activity in groundwater remains below the $15 \mathrm{pCi} / \mathrm{L}$ standard and peaks at the end of the compliance period with a concentration of approximately $5 \mathrm{pCi} / \mathrm{L}$ (Table 4-8).

2. Letter from S. P. Cowan to J. T. Case, June 20, 1996, "Groundwater Compliance for the Low-Level Waste Radiological Performance Assessment for the Radioactive Waste Management Complex at the Idaho National Engineering Laboratory." 
Table 4-8. Peak dose $100 \mathrm{~m}$ downgradient of the SDA during the 1,000 year compliance period.

\begin{tabular}{|c|c|c|c|c|}
\hline Radionuclide & Year of maximum & $\begin{array}{c}\text { Maximum direct } \\
\text { ingestion dose (mrem/yr) }\end{array}$ & $\begin{array}{l}\text { Maximum all pathways } \\
\text { Dose (mrem/yr) }\end{array}$ & $\begin{array}{c}\text { Maximum concentration } \\
\text { (pCi } / \text { ) }\end{array}$ \\
\hline Ac227 & 2999 & $1.34 \mathrm{E}-01$ & $1.42 \mathrm{E}-01$ & $1.31 \mathrm{E}-02$ \\
\hline Am241 & 2999 & $1.52 \mathrm{E}-02$ & $1.60 \mathrm{E}-02$ & 4.84E-03 \\
\hline $\operatorname{Am} 243$ & 2999 & 1.22E-07 & $1.28 \mathrm{E}-07$ & $3.87 \mathrm{E}-08$ \\
\hline C14 & 2245 & $6.62 E+00$ & $2.66 \mathrm{E}+01$ & $4.51 E+03$ \\
\hline $\mathrm{Cl} 36$ & 2253 & $3.85 E-02$ & $1.63 \mathrm{E}+00$ & $1.84 \mathrm{E}+01$ \\
\hline $\mathrm{Cm} 244$ & $2120^{1}$ & $1.95 \mathrm{E}-10$ & $2.05 \mathrm{E}-10$ & $1.21 \mathrm{E}-10$ \\
\hline Co60 & $2120^{2}$ & $1.92 \mathrm{E}-16$ & $4.42 \mathrm{E}-16$ & $1.06 \mathrm{E}-14$ \\
\hline $\operatorname{Cs137}$ & $2120^{1}$ & $5.20 \mathrm{E}-09$ & $1.43 \mathrm{E}-08$ & $1.49 \mathrm{E}-07$ \\
\hline Eu1s2 & $2055^{1}$ & $2.88 \mathrm{E}-13$ & $3.81 \mathrm{E}-13$ & $6.86 \mathrm{E}-11$ \\
\hline Eu154 & $2120^{1}$ & $5.16 \mathrm{E}-12$ & $6.82 \mathrm{E}-12$ & $8.09 \mathrm{E}-10$ \\
\hline H3 & $2120^{1}$ & $2.27 \mathrm{E}-02$ & 6.57E-02 & $5.15 E+02$ \\
\hline I129 & 2245 & $3.01 E+00$ & $6.94 E+00$ & $1.54 \mathrm{E}+01$ \\
\hline $\mathrm{N} 222$ & $2120^{1}$ & $4.20 \mathrm{E}-16$ & $2.95 \mathrm{E}-15$ & $5.00 \mathrm{E}-14$ \\
\hline $\mathrm{Nb94}$ & 2999 & $1.49 \mathrm{E}-11$ & $2.43 \mathrm{E}-10$ & 4.18E-09 \\
\hline Ni59 & 2999 & $1.36 \mathrm{E}-07$ & $2.00 \mathrm{E}-07$ & $9.68 \mathrm{E}-04$ \\
\hline Ni63 & 2396 & $1.14 \mathrm{E}-07$ & $1.69 \mathrm{E}-07$ & $3.02 \mathrm{E}-04$ \\
\hline Np237 & 2999 & $1.36 \mathrm{E}+01$ & $1.44 \mathrm{E}+01$ & $4.99 \mathrm{E}+00$ \\
\hline Pa231 & 2999 & $3.71 \mathrm{E}-01$ & $3.90 \mathrm{E}-01$ & $4.82 \mathrm{E}-02$ \\
\hline $\mathrm{Pb} 210$ & 2999 & $1.59 \mathrm{E}-03$ & $1.71 E-03$ & $4.46 \mathrm{E}-04$ \\
\hline Pu238 & 2396 & $1.33 E-10$ & $1.40 \mathrm{E}-10$ & $5.01 E-11$ \\
\hline Pu239 & 2999 & $2.01 \mathrm{E}-06$ & $2.11 \mathrm{E}-06$ & 6.67E-07 \\
\hline Pu240 & 2999 & $4.26 \mathrm{E}-07$ & 4.47E-07 & $1.42 \mathrm{E}-07$ \\
\hline Pu241 & $2120^{1}$ & $1.83 \mathrm{E}-13$ & $1.93 \mathrm{E}-13$ & 3.05E-12 \\
\hline Pu242 & 2999 & $2.83 \mathrm{E}-11$ & $2.97 \mathrm{E}-11$ & $9.85 E-12$ \\
\hline $\operatorname{Ra226}$ & 2999 & 2.45E-04 & $2.70 \mathrm{E}-04$ & $3.18 \mathrm{E}-04$ \\
\hline $\operatorname{Ra228}$ & 2999 & 4.73E-08 & $5.21 E-08$ & $5.63 E-08$ \\
\hline $8+90$ & $2120^{1}$ & $1.59 \mathrm{E}-04$ & 2.03E-04 & $1.75 E-03$ \\
\hline Tल99 & 2846 & 8.73E-03 & $2.88 \mathrm{E}-02$ & $9.60 \mathrm{E}+00$ \\
\hline Th228 & 2271 & $1.82 \mathrm{E}-03$ & $1.91 \mathrm{E}-03$ & $3.45 \mathrm{E}-03$ \\
\hline Th229 & 2999 & $4.03 \mathrm{E}-03$ & $4.24 \mathrm{E}-03$ & 1.47E-03 \\
\hline Th230 & 2999 & $3.05 E-03$ & $3.21 E-03$ & $8.23 E-03$ \\
\hline Th232 & 2999 & $1.38 \mathrm{E}-07$ & $1.45 \mathrm{E}-07$ & $7.06 \mathrm{E}-08$ \\
\hline U232 & 2271 & $6.60 \mathrm{E}-03$ & 7.34E-03 & 7.25E-03 \\
\hline U233 & 2999 & 9.35E-02 & $1.04 \mathrm{E}-01$ & $4.95 \mathrm{E}-01$ \\
\hline U234 & 2999 & $1.04 \mathrm{E}+01$ & $1.15 E+01$ & $5.69 \mathrm{E}+01$ \\
\hline U235 & 2999 & 7.55E-01 & $8.40 \mathrm{E}-01$ & $4.31 \mathrm{E}+00$ \\
\hline U236 & 2999 & $3.20 \mathrm{E}-01$ & $3.56 \mathrm{E}-01$ & $1.83 \mathrm{E}+00$ \\
\hline U238 & 2999 & $1.62 \mathrm{E}+01$ & $1.80 \mathrm{E}+01$ & $9.42 \mathrm{E}+01$ \\
\hline Total & 2999 & $4.50 \mathrm{E}+01$ & $5.81 E+01$ & NA \\
\hline Total $\alpha$ & 2999 & NA & NA & $5.13 E+00$ \\
\hline $\operatorname{Total} \beta-\gamma$ & 2245 & $9.68 \mathrm{E}+00$ & NA & NA \\
\hline
\end{tabular}


The peak dose at the INEEL boundary for the period of institutional control (1997 to 2120) is negligible. The maximum dose at the INEEL boundary during the institutional control period is approximately $0.07 \mathrm{mrem} / \mathrm{yr}$ for groundwater ingestion and $0.23 \mathrm{mrem} / \mathrm{yr}$ for all pathways. The largest predicted dose is from C-14, with a maximum direct groundwater ingestion dose of $0.04 \mathrm{mrem} / \mathrm{yr}$ and all pathways dose of $0.18 \mathrm{mrem} / \mathrm{yr}$.

\subsubsection{Dose Trends}

The Composite Analysis indicates that the projected all pathways dose will exceed the $30 \mathrm{mrem} / \mathrm{yr}$ dose constraint around the year 2,200 and will continue to rise and reach an initial peak at approximately the year 2250 (Figure 4-9). The projected all pathways dose is then predicted to decrease below the 30 mrem/yr dose constraint and continue to decrease until around the year 2,550; thereafter, the all pathways dose is expected to continuously rise through the remainder of the 1,000 yr compliance period (Figure 4-9). The projected groundwater ingestion dose is predicted to continuously rise throughout the $1,000 \mathrm{yr}$ compliance period (Figure 4-9). The peak dose values for groundwater ingestion and all pathways occur at the end of the compliance period (Figure 4-9).

The dose trends of the significant radionuclide components of the all pathways dose during the 1,000 yr compliance period are given in Figure 4-10. The results indicate that the all pathways dose contribution of long-lived actinides will increase throughout the compliance period (Figure 4-10). The simulations predict that the all pathways dose attributed to C-14 rises within the $1,000 \mathrm{yr}$ compliance period until the year 2245 and then decreases thereafter (Figure 4-10). The peaking and diminishing dose from C-14 combined with the effect of continuously increasing actinide dose results in the crest and trough trend in the all pathways dose during the $1,000 \mathrm{yr}$ compliance period.

Similarly, the CA predicts that the groundwater ingestion dose contribution of long-lived actinides will increase throughout the compliance period (Figure 4-11). The groundwater ingestion dose attributed to C-14 is predicted to rise during the $1,000 \mathrm{yr}$ compliance period until the year 2245 with a peak of approximately $7 \mathrm{mrem} / \mathrm{yr}$ and then decreases thereafter (Figure 4-11).

Beyond the 1,000 year compliance period, the presence of long lived actinides in groundwater may pose particular concerns. Figure 4-12 shows the predicted total uranium concentration in groundwrater at $100 \mathrm{~m}$ (328 ft) downgradient from the SDA boundary for 10,000 years simulation. The uranium concentration has risen to $0.26 \mathrm{mg} / \mathrm{L}$ by the year 3,000 and exceeds the proposed MCL of $0.02 \mathrm{mg} / \mathrm{L}$ and is predicted to eventually rise to $1.17 \mathrm{mg} / \mathrm{L}$ (Figure 4-12). The peak all pathways dose for 10,000 years simulation at $100 \mathrm{~m}$ (328 $\mathrm{ft})$ downgradient from the SDA boundary is predicted to be $340 \mathrm{mrem} / \mathrm{yr}$ for and is primarily attributed to actinides including isotopes of uranium as well as $\mathrm{Np}-237$ (Table 4-9). It should be noted that there is relatively high uncertainty in the available mobility and solubility data for actinides. Investigations are underway to provide better site-specific data to be used in future radiological performance and risk assessments at INEEL. 


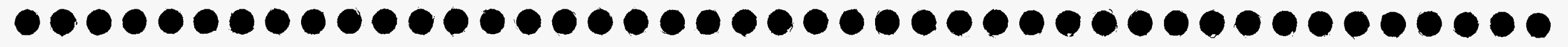

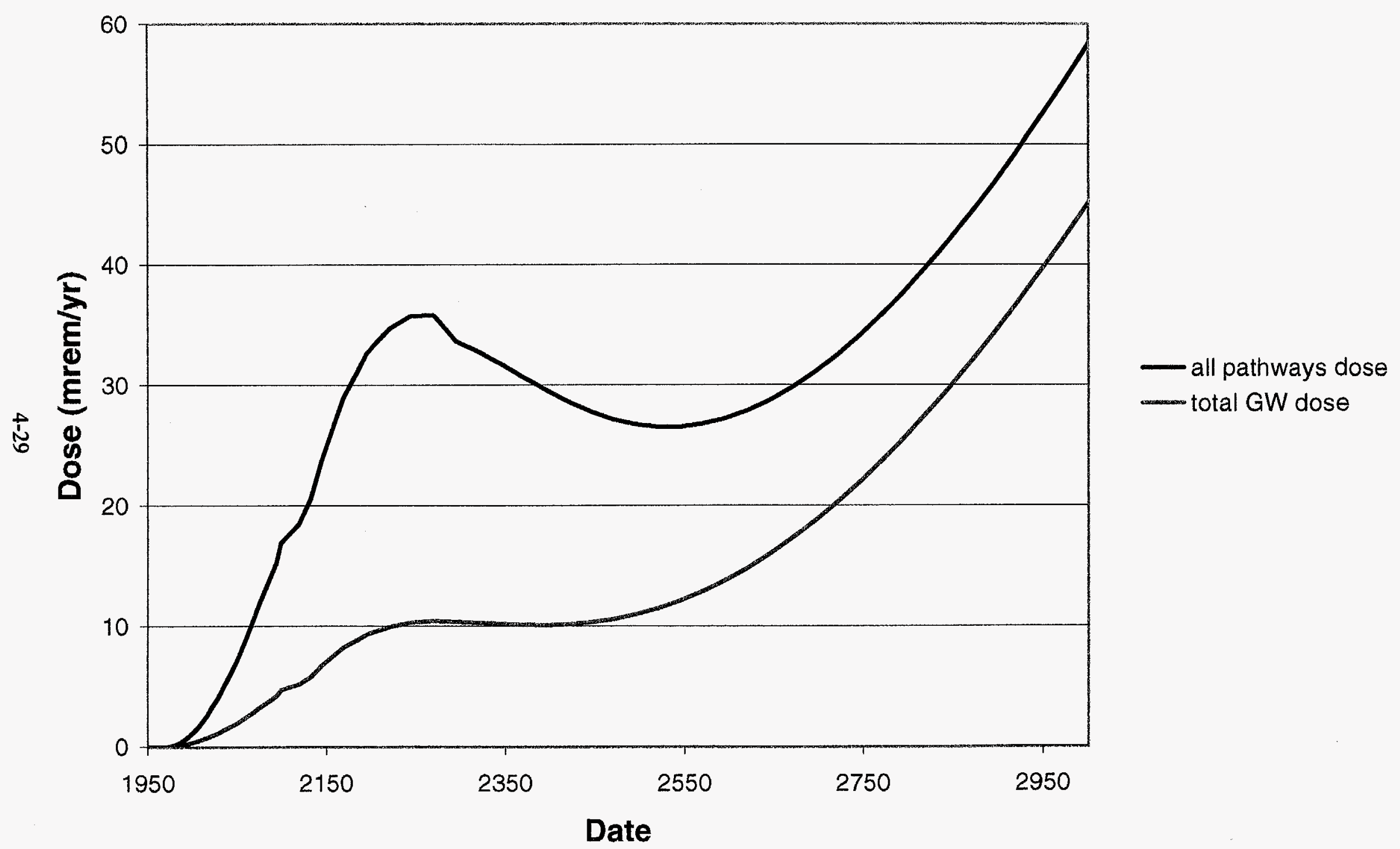

Figure 4-9. Total all-pathways and groundwater ingestion dose at $100 \mathrm{~m}$ downgradient from the SDA boundary during the 1,000 year compliance period. 


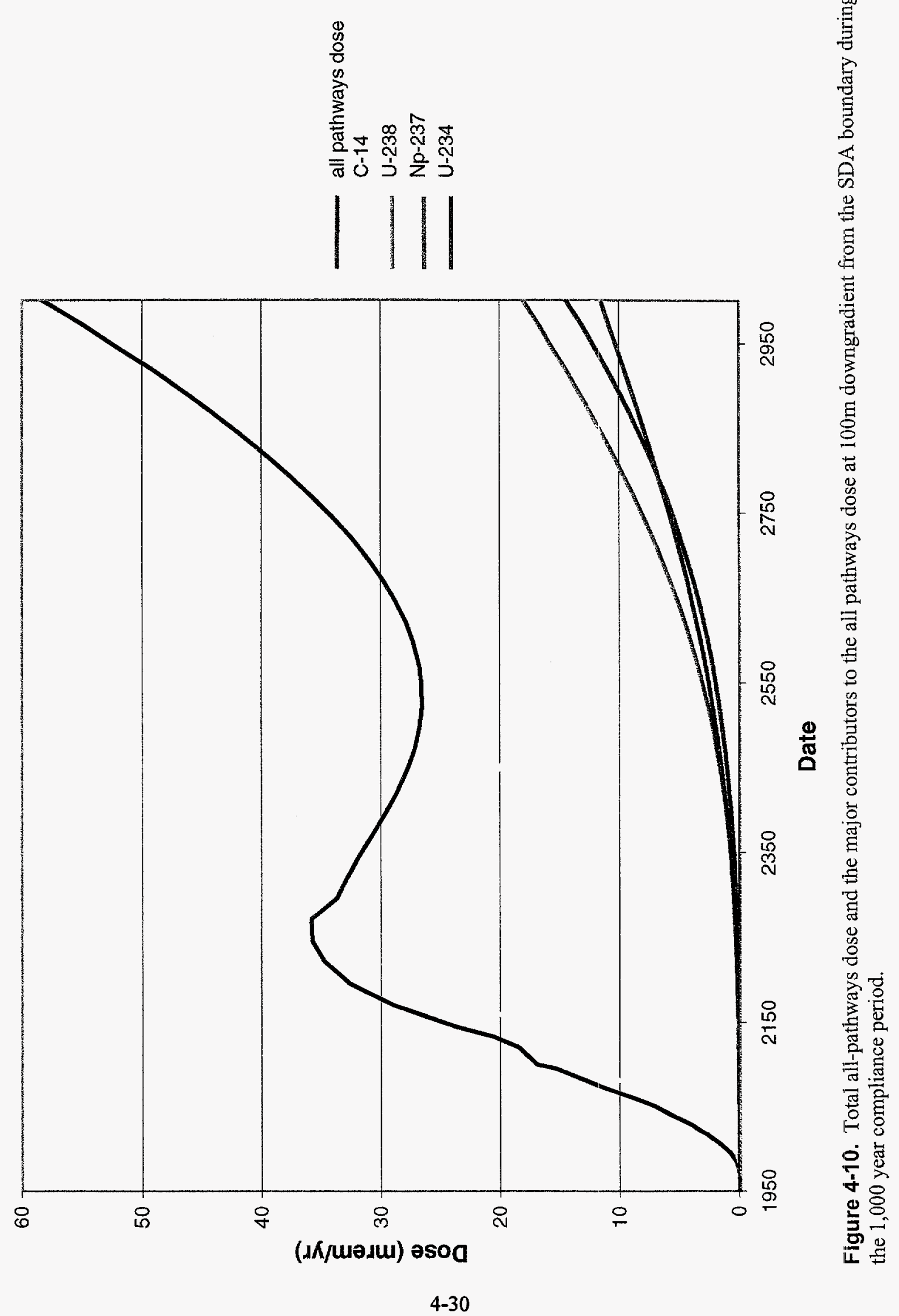




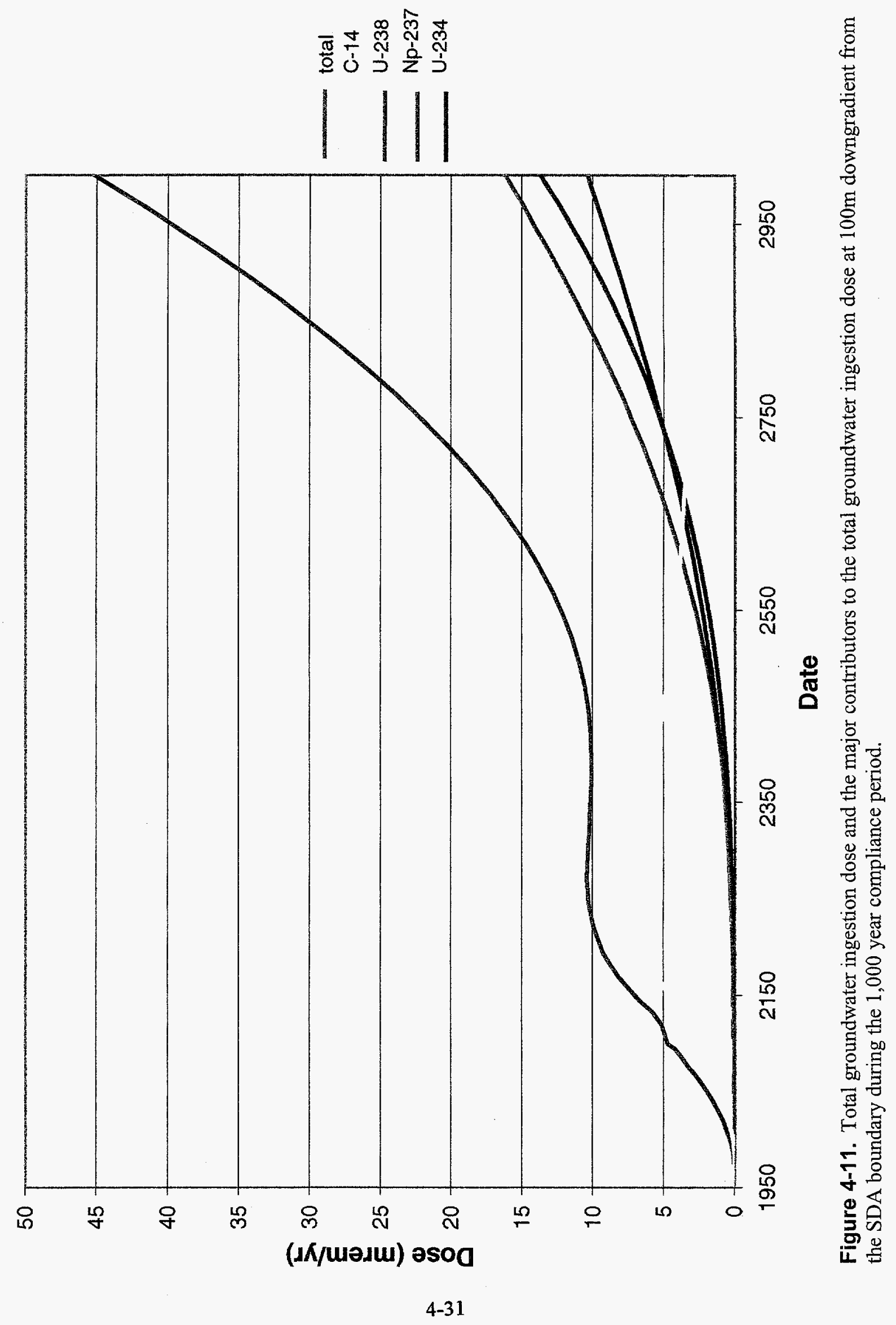




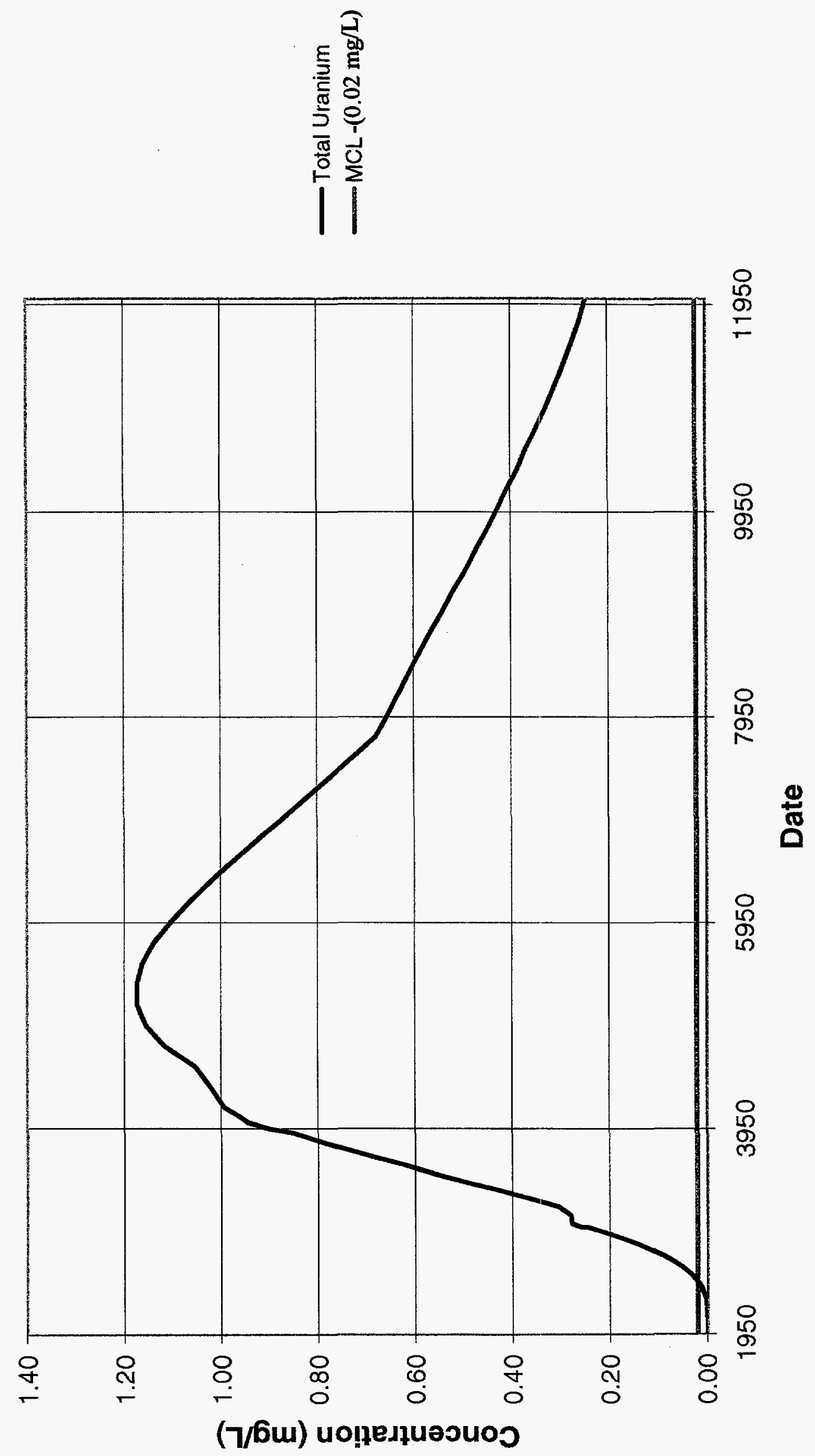

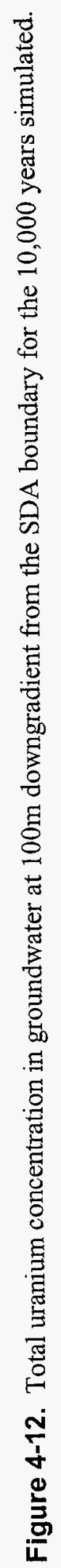


Table 4-9. Peak dose $100 \mathrm{~m}$ downgradient of the SDA up to 10,000 years.

\begin{tabular}{|c|c|c|c|c|}
\hline Radionuclide & Year of maximum & $\begin{array}{l}\text { Maximum direct } \\
\text { ingestion dose } \\
(\mathrm{mrem} / \mathrm{yr})\end{array}$ & $\begin{array}{c}\text { Maximum all } \\
\text { pathways Dose } \\
\text { (mrem/yr) }\end{array}$ & $\begin{array}{c}\text { Maximum } \\
\text { concentration } \\
\text { (pCi/L) }\end{array}$ \\
\hline Ac227 & 8557 & $3.15 E+00$ & $3.32 \mathrm{E}+00$ & $3.09 E-01$ \\
\hline Am241 & 3833 & $2.36 \mathrm{E}-02$ & $2.48 \mathrm{E}-02$ & $7.49 \mathrm{E}-03$ \\
\hline Am243 & 12010 & $1.95 \mathrm{E}-05$ & $2.05 \mathrm{E}-05$ & $6.20 \mathrm{E}-06$ \\
\hline C14 & 2245 & $6.62 \mathrm{E}+00$ & $2.66 \mathrm{E}+01$ & $4.51 E+03$ \\
\hline $\mathrm{Cl} 36$ & 2253 & $3.85 \mathrm{E}-02$ & $1.63 \mathrm{E}+00$ & $1.84 \mathrm{E}+01$ \\
\hline Cm244 & $2120^{1}$ & $1.95 \mathrm{E}-10$ & 2.05E-10 & $1.21 \mathrm{E}-10$ \\
\hline $\mathrm{C} 060$ & $2120^{1}$ & $1.92 \mathrm{E}-16$ & $4.42 E-16$ & $1.06 \mathrm{E}-14$ \\
\hline $\operatorname{Cs} 137$ & $2120^{l}$ & $5.20 \mathrm{E}-09$ & $1.43 \mathrm{E}-08$ & $1.49 \mathrm{E}-07$ \\
\hline Eu152 & $2055^{1}$ & $2.88 \mathrm{E}-13$ & $3.81 E-13$ & $6.86 \mathrm{E}-11$ \\
\hline Eul54 & $2120^{1}$ & $5.16 \mathrm{E}-12$ & $6.82 \mathrm{E}-12$ & $8.09 \mathrm{E}-10$ \\
\hline H3 & $2120^{1}$ & $2.27 \mathrm{E}-02$ & $6.57 \mathrm{E}-02$ & $5.15 E+02$ \\
\hline I129 & 2245 & $3.01 E+00$ & $6.94 \mathrm{E}+00$ & $1.54 \mathrm{E}+01$ \\
\hline $\mathrm{Na22}$ & $2120^{1}$ & $4.20 \mathrm{E}-16$ & $2.95 \mathrm{E}-15$ & $5.00 \mathrm{E}-14$ \\
\hline Nb94 & 11760 & $1.01 \mathrm{E}-07$ & $1.65 \mathrm{E}-06$ & $2.83 E-05$ \\
\hline Ni59 & 11760 & $5.88 E-05$ & $8.69 \mathrm{E}-05$ & $4.20 \mathrm{E}-01$ \\
\hline Ni63 & 2396 & $1.14 \mathrm{E}-07$ & $1.69 \mathrm{E}-07$ & $3.02 \mathrm{E}-04$ \\
\hline Np237 & 6355 & $2.15 E+02$ & $2.27 \mathrm{E}+02$ & $7.88 \mathrm{E}+01$ \\
\hline $\mathrm{Pa} 231$ & 6555 & $5.93 \mathrm{E}+00$ & $6.23 E+00$ & $7.70 \mathrm{E}-01$ \\
\hline $\mathrm{Pb} 210$ & 12010 & $8.24 \mathrm{E}-01$ & $8.85 \mathrm{E}-01$ & $2.31 \mathrm{E}-01$ \\
\hline $\mathrm{Pb} 210$ & 12010 & $2.31 E-02$ & $2.48 \mathrm{E}-02$ & $6.48 E-03$ \\
\hline Pu238 & 2396 & 1.33E-10 & $1.40 \mathrm{E}-10$ & $5.01 \mathrm{E}-11$ \\
\hline Pu239 & 12010 & $1.52 \mathrm{E}-03$ & $1.60 \mathrm{E}-03$ & $5.06 \mathrm{E}-04$ \\
\hline $\mathrm{Pu} 240$ & 12010 & 1.61E-04 & $1.69 \mathrm{E}-04$ & $5.37 \mathrm{E}-05$ \\
\hline Pu241 & $2120^{1}$ & $1.83 \mathrm{E}-13$ & $1.93 \mathrm{E}-13$ & $3.05 \mathrm{E}-12$ \\
\hline $\mathrm{Pu} 242$ & 12010 & $2.74 \mathrm{E}-08$ & $2.87 \mathrm{E}-08$ & $9.54 \mathrm{E}-09$ \\
\hline $\operatorname{Ra226}$ & 12010 & $9.36 \mathrm{E}-02$ & $1.03 E-01$ & $1.22 \mathrm{E}-01$ \\
\hline $\operatorname{Ra226}$ & 12010 & $2.65 \mathrm{E}-03$ & $2.92 \mathrm{E}-03$ & $3.44 \mathrm{E}-03$ \\
\hline $\operatorname{Ra228}$ & 12010 & $3.10 \mathrm{E}-05$ & $3.42 \mathrm{E}-05$ & $3.69 \mathrm{E}-05$ \\
\hline Sr90 & $2120^{1}$ & $1.59 \mathrm{E}-04$ & $2.03 \mathrm{E}-04$ & $1.75 \mathrm{E}-03$ \\
\hline Tc99 & 2846 & $8.74 \mathrm{E}-03$ & $2.88 \mathrm{E}-02$ & $9.60 \mathrm{E}+00$ \\
\hline Th228 & 12010 & $1.75 \mathrm{E}-05$ & $1.84 \mathrm{E}-05$ & $3.32 \mathrm{E}-05$ \\
\hline Th228 & 2271 & $1.82 \mathrm{E}-03$ & $1.91 \mathrm{E}-03$ & $3.45 \mathrm{E}-03$ \\
\hline Th229 & 10160 & 8.47E-02 & $8.90 \mathrm{E}-02$ & $3.10 \mathrm{E}-02$ \\
\hline $\operatorname{Th} 230$ & 11760 & $3.85 \mathrm{E}-02$ & $4.04 E-02$ & $1.04 \mathrm{E}-01$ \\
\hline
\end{tabular}


Table 4-9. (continued).

\begin{tabular}{ccccc}
\hline Radionuclide & Year of maximum & $\begin{array}{c}\text { Maximum direct } \\
\text { ingestion dose } \\
\text { (mrem/yr) }\end{array}$ & $\begin{array}{c}\text { Maximum all } \\
\text { pathways Dose } \\
\text { (mrem/yr) }\end{array}$ & $\begin{array}{c}\text { Maximum } \\
\text { concentration } \\
\text { (pCi } / \text { ) }\end{array}$ \\
\hline Th230 & 12010 & $1.37 \mathrm{E}-03$ & $1.44 \mathrm{E}-03$ & $3.70 \mathrm{E}-03$ \\
Th232 & 12010 & $9.37 \mathrm{E}-05$ & $9.84 \mathrm{E}-05$ & $4.78 \mathrm{E}-05$ \\
$\mathrm{U} 232$ & 2271 & $6.60 \mathrm{E}-03$ & $7.34 \mathrm{E}-03$ & $7.25 \mathrm{E}-03$ \\
U233 & 5955 & $4.98 \mathrm{E}-01$ & $5.54 \mathrm{E}-01$ & $2.63 \mathrm{E}+00$ \\
U234 & 4755 & $3.39 \mathrm{E}+01$ & $3.77 \mathrm{E}+01$ & $1.86 \mathrm{E}+02$ \\
U234 & 5955 & $8.59 \mathrm{E}-01$ & $9.56 \mathrm{E}-01$ & $4.72 \mathrm{E}+00$ \\
U235 & 4755 & $2.52 \mathrm{E}+00$ & $2.80 \mathrm{E}+00$ & $1.44 \mathrm{E}+01$ \\
U236 & 5355 & $1.31 \mathrm{E}+00$ & $1.46 \mathrm{E}+00$ & $7.50 \mathrm{E}+00$ \\
U238 & 4755 & $6.76 \mathrm{E}+01$ & $7.52 \mathrm{E}+01$ & $3.94 \mathrm{E}+02$ \\
Total & 5555 & $3.14 \mathrm{E}+02$ & $3.40 \mathrm{E}+02$ & NA \\
Total $\alpha$ & 6355 & NA & NA & $8.11 \mathrm{E}+01$ \\
Total $\beta-\gamma$ & 2245 & 9.68 & NA & NA \\
\hline 1) Peak occurs before the end of the institutional control period (2120). & & & \\
\hline
\end{tabular}




\section{UNCERTAINTY AND SENSITIVITY ANALYSIS}

This section discusses the results of the sensitivity and uncertainty analysis performed for the Composite Analysis. Uncertainty analysis is the process by which uncertainty in the model input, and uncertainty in the model are evaluated and expressed in terms of the overall precision of the output variable. Precision of the output variable is usually expressed as a distribution of possible values within which lies the true, but unknown value. Sensitivity analysis is used to assess the sensitivity of the output variable on changes in input parameter values. Model complexity and limited field data restricted this analysis to a semi-quantitative approach that is discussed in the following sections.

\subsection{Uncertainty Analysis}

Uncertainty typically has two components; parameter uncertainty and model uncertainty. Model uncertainty addresses the degree to which a model represents a physical system. All models are simplifications of a real physical system. Model uncertainty is evaluated by comparing model predictions with field measurements. Parameter uncertainty evaluates the uncertainty in a model output variable given input variables are represented by distributions of possible values instead of a single fixed value. Parameter uncertainty typically requires a Monte Carlo approach where numerous model simulations are performed. For each simulation, parameter values are randomly sampled from user-provided distributions, the model is run, and the output variable is stored. Upon completion, a distribution of the output variable is then provided. For the composite analysis, quantitative parameter uncertainty analysis is not feasible due to the complexity of the model and the computer run-time required.

Uncertainty in the dose estimates made for the Composite Analysis may be attributed to uncertainty in: (1) source inventory, (2) source release mechanisms, (3) transport modeling, and (4) dose conversion factors. The first three items in the list above contribute to the uncertainty in the estimated groundwater concentration at the receptor point. The last item considers the uncertainty in the calculated radiological dose once radionuclides are ingested and is independent of the other three. Because doses are calculated to hypothetical and not real individuals, receptor physical attributes and behavior may be considered fixed for all time. The receptor represents a single individual who exhibits a given behavior and has fixed physical attributes. A population of receptors is not considered and therefore, variability within the population is not expressed in the uncertainty. Receptor behaviors (i.e. drinking water consumption rates, time and duration of exposure) were taken from EPA literature and represented upper-bound estimates of these parameters that maximize exposure to the receptor. Uncertainty in the Composite Analysis is attributed to: (1) source term uncertainty, (2) model uncertainty, (3) parameter uncertainty, and (4) dose conversion factor uncertainty and is discussed in the following sections in a qualitative manner.

\subsubsection{Source Term Uncertainty}

Efforts to estimate the uncertainty in radionuclide inventories reported in CIDRA are detailed in LMTTCO (1995a and b). Statistical methods were employed to obtain the CIDRA bestestimate and associated uncertainties which are presented as upper- and lower-bound values. Sources of uncertainty in CIDRA radionuclide data include error in the measurement bias 
correction, error in the measurement method, error in scaling factors used to estimate radionuclide distributions, and random error. Standard error propagation techniques (NCRPM 1985) and the applicable uncertainties were used to estimate the overall uncertainty in the CIDRA best-estimate values expressed as upper- and lower-bounds. Defensible uncertainty estimates for CIDRA bestestimate values relied on professional judgement, reasonable assumptions; as well as, standard statistical techniques and are considered analogous to $95 \%$ confidence limit values with reasonable certainty.

\subsubsection{Model Uncertainty}

Model uncertainty addresses the degree to which a model represents the physical systern that the model simulates. All models are simplifications of a real physical system. The source term model was calibrated indirectly during the groundwater calibration. The sensitivity of contaminants to selected hydrologic and transport parameters was qualitatively determined during the flow-and-transport calibration process and resulted in the following observations:

- Nitrate calibration is uncertain because of limited data that do not clearly indicate a contribution from the SDA to observed aquifer concentrations. By assuming there is a contribution above the local estimated background, the model is conservative since the contaminants are modeled with the assumption of having reached the aquifer by dissolved-phase transport, and travel time would be underestimated.

- The modeled concentrations in the deeper vadose zone and in the SRPA were found to be insensitive to the choice of a transient or equivalent constant infiltration rate. This finding was based on the assumption of equilibrium partitioning of contaminants between the sorbed and dissolved phases.

- The modeled aquifer concentrations were relatively insensitive to longitudinal dispersivity in general; however, they were somewhat sensitive to transverse dispersion.

- The method of assigning sorption based on fracture surface areas resulted in low effective $\mathrm{K}_{d} \mathrm{~s}$ and was essentially equivalent to assigning no sorption in the basalt. The upper portion of the aquifer is assumed to be composed of fractured basalt. Therefore, the aquifer is assumed to have little sorption for all radionuclides.

- The presence of a low permeability region in the aquifer beneath the southern half of the SDA has a measurable effect on the simulated concentrations at the compliance receptor location. The low permeability is observed in transmissivity estimates from single-well pumping tests. The zone over which this low permeability region persists is uncertain.

- For gaseous phase transport, the sensitivity to boundary condition influences was most pronounced for atmospheric pressure fluctuations at land surface, positive pressure air injection during well drilling, and to vapor extraction activities.

- The transport of gaseous phase contaminants was sensitive to diffusion, which is controlled by tortuosity. The uncertainty associated with tortuosity is large. 
- Although there was a sensitivity to hydrologic parameters in general, the contaminant concentrations in both the aqueous and gaseous phases were generally found to be much more sensitive to the inventory and simulated source release mechanisms than any of the hydrologic parameters in the subsurface transport model.

\subsubsection{Parameter Uncertainty}

Model input parameters have associated uncertainties. Site-specific data and data from literature were reviewed to determine parameter values appropriate for conditions at the SDA including:

- Lithologic descriptions of the environment which describe the relative thickness of the basalt flows and the interbeds in the subsurface model as measured in lithologic logs.

- Heterogeneous hydraulic parameters.

- Soil-to-water partition coefficients developed from column tests of native soils and national databases.

- Container failure data taken from waste retrieval operations.

- Beryllium reflector block corrosion rates estimated analytically and from sampling.

- Stainless steel corrosion rates from published reports on corrosion.

- The contaminant inventory developed from disposal records and subsequent refinements.

\subsubsection{Dose Conversion Factor Uncertainty}

The dose conversion factors (DCFs) used in this assessment are DOE recommended values based on the latest International Atomic Energy Agency methodology, however, the DCFs have some uncertainty associated with them. Primarily due to the extrapolation from high dose to low dose and from animal data to human data. Although the Composite Analysis contains considerable sources of uncertainty, the consistent adoption of conservative assumptions and parameter values, and adherence to EPA and DOE guideline recommendations are considered to provide reasonably conservative estimates of the cumulative impacts from the LLW facility and other radiological sources that may interact with the facility to affect the dose to future members of the public.

\subsection{Sensitivity Analysis}

Model sensitivity simulations were performed to address:

- mobility - the $K_{d}$ for selected dose contributors was modified to determine the effect on the predicted doses. 
- infiltration rate - the infiltration rate inside the SDA was decreased to simulate the effect of emplacing a cap to determine the effect on the predicted doses.

- dual-phase transport - Carbon-14 was simulated for the CA as if it only moved in the dissolved phase. Dual-phase transport of C-14 was simulated to detemine effects on predicted doses.

- release rate - the corrosion rate of steel was modified to determine the potential effect of changing the release of activation products from metals.

Model sensitivity simulations were performed using CIDRA upper-bound inventories and best-estimate inventories. Doses calculated in each simulation are generally based on maximum aquifer concentrations at a distance of $100 \mathrm{~m}(328 \mathrm{ft})$ downgradient from the SDA boundary, with some exceptions.

\subsubsection{Model Sensitivity to Contaminant Mobility}

The effect of changing the mobility of Am-241 and Np-237 was used to evaluate uncertainty associated with the assigned partition coefficients $\left(K_{d}\right) . N p-237$ is identified as a potential risk driver and is a daughter product of Am-241. The simulations were performed with upper-bound CIDRA inventories. Table 5-1 presents the $K_{d}$ values used in the base simulation and the three simulations performed for this analysis. The $\mathrm{K}_{\mathrm{d}} \mathrm{s}$ were varied by a factor of two from the base case values. The Am-241 groundwater dose (mrem/yr) results are shown in Figure 5-1 and the Np-237 groundwater dose (mrem/yr) results are shown in Figure 5-2. The Am-241 results show different peak dose but do not show a different time of peak because the results were dominated by dispersion in the model, not the advective flow. The peak concentrations and doses result when the dispersive front reaches the aquifer because the half-life of Am-241 is short relative to the retarded advective travel time to the aquifer. The $\mathrm{Np}-237$ results show differing peaks and differing times of the peaks as expected from the changing $K_{d}$ values because the $N p-237$ half life is long relative to the retarded travel time through the vadose zone. Table 5-2 presents a summary of the Am-241 and Np-237 dose results. As can be seen, a change in the $K_{d}$ by a factor of 2 results in a corresponding change in the dose result by roughly a factor of 2 as well. Since Np-237 is released by the surface rinse release mechanism, changing the $K_{d}$ changes both the mobility and the contaminant release rate. It is not known from these results if a contaminant that was released by a different mechanism would be as sensitive to changes in the $\mathrm{K}_{\mathrm{d}}$.

Table 5-1. $\mathrm{K}_{d}$ values used in the mobility sensitivity cases.

\begin{tabular}{lcc}
\hline Simulation & $\mathrm{Am}-241 \mathrm{~K}_{\mathrm{d}}(\mathrm{mL} / \mathrm{g})$ & $\mathrm{Np}-237 \mathrm{~K}_{\mathrm{d}}(\mathrm{mL} / \mathrm{g})$ \\
\hline Base Case & 450 & 8 \\
Case 2 & 225 & 16 \\
Case 3 & 900 & 4 \\
Case 4 & 225 & 4 \\
\hline
\end{tabular}




\section{$\bullet \bullet \bullet \bullet \bullet \bullet \bullet \bullet \bullet \bullet \bullet \bullet \bullet \bullet \bullet \bullet \bullet \bullet \bullet \bullet \bullet \bullet \bullet \bullet \bullet \bullet \bullet \bullet \bullet \bullet \bullet \bullet \bullet \bullet \bullet \bullet \bullet \bullet \bullet \bullet \bullet \bullet \bullet$}

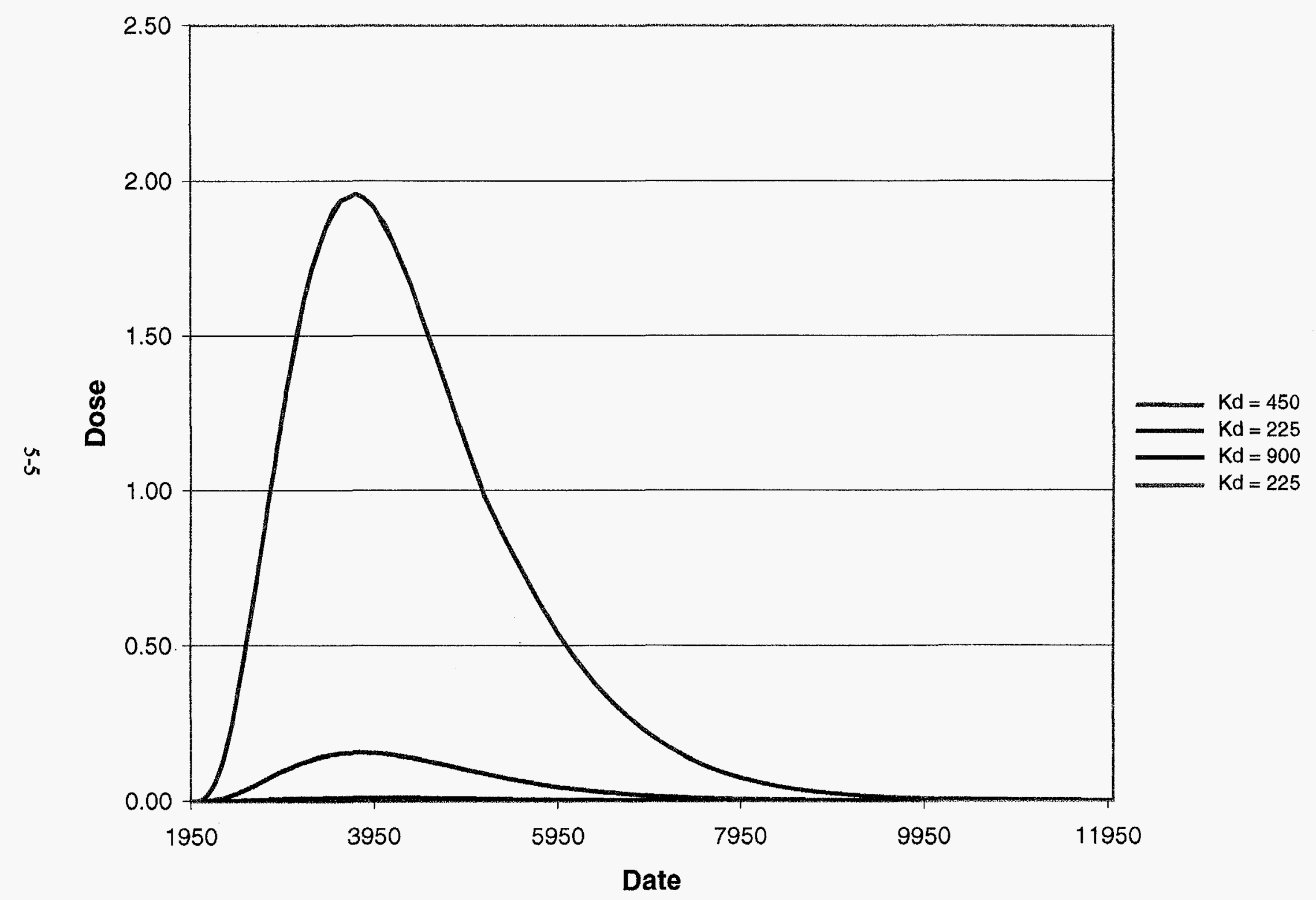

Figure 5-1. Effect of changing the mobility $\left(\mathrm{K}_{\mathrm{d}}\right)$ of Am-241. 


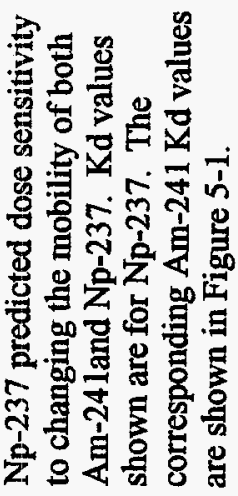

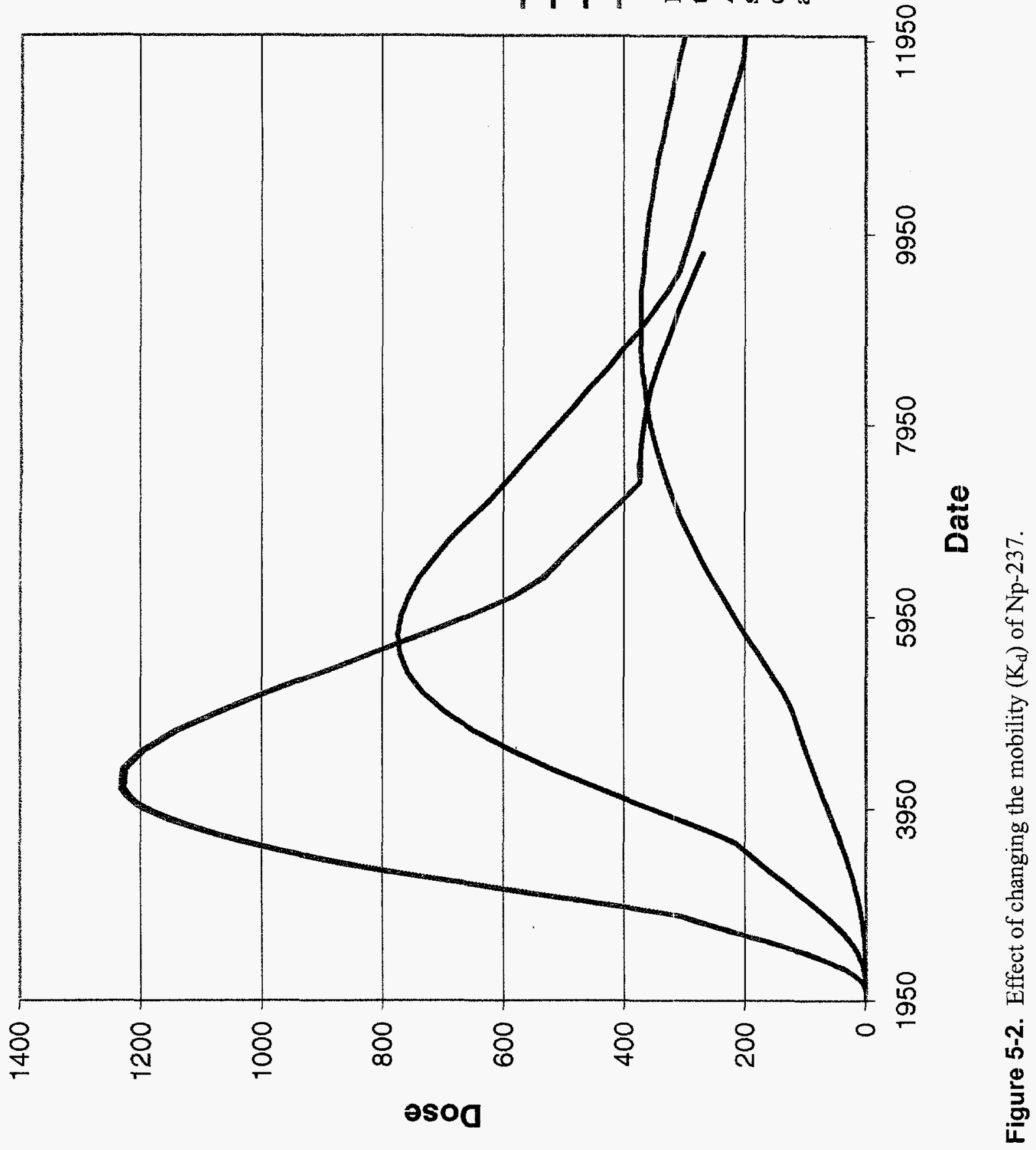


Table 5-2. Am-241 and Np-237 peak groundwater dose.

\begin{tabular}{lllll}
\hline & \multicolumn{3}{c}{ Am-241 } & Np-237 \\
\hline Simulation & $\begin{array}{l}\text { Time of Peak } \\
\text { Groundwater } \\
\text { Dose (yr) }\end{array}$ & $\begin{array}{l}\text { Peak } \\
\text { Groundwater } \\
\text { Dose (mrem/yr) }\end{array}$ & $\begin{array}{l}\text { Time of Peak } \\
\text { Groundwater } \\
\text { Dose (yr) }\end{array}$ & $\begin{array}{l}\text { Peak Groundwater } \\
\text { Dose (mrem/yr) }\end{array}$ \\
\hline Base Case & 3750 & 0.156 & 5755 & 780 \\
Case 2 & 3750 & 1.96 & 9050 & 370 \\
Case 3 & 3830 & 0.0114 & 4150 & 1200 \\
Case 4 & 3750 & 1.94 & 4150 & 1200
\end{tabular}

The values use upper-bound estimates of the waste inventory and were run for the RWMC-IRA so the relative doses are of interest but the absolute values are unrelated to the Composite Analysis.

Carbon-14 was also identified as a potential dose-driver in the CA. Studies were initiated to better define the site-specific partition coefficient onto SDA soils. Batch test results showed the $\mathrm{K}_{\mathrm{d}}$ was within the range from 0.1 to $1.5 \mathrm{~mL} / \mathrm{g}$ (Dicke 1998). Dissolved-phase (single-phase) simulations were conducted using this site-specific $K_{d}$ range. Figure 5-3 shows the predicted doses for the $K_{d}$ range and Table 5-3 contains the maximum doses. The lower $K_{d}$ of $0.1 \mathrm{~mL} / \mathrm{g}$ results in a maximum dose of $26.6 \mathrm{mrem} / \mathrm{yr}$ while the higher $\mathrm{K}_{d}$ of $1.5 \mathrm{~mL} / \mathrm{g}$ results in a dose of 9.65 mrem/yr. This is a factor of 2.75 reduction in the total dose. The sensitivity of the dose to changes in the $\mathrm{Kd}$ value increases for radionuclides with short half-lives relative to their travel time in the vadose zone and aquifer.

Table 5-3. Range of $\mathrm{K}_{\mathrm{d}}$ values used for $\mathrm{C}-14$ and resulting peak.

\begin{tabular}{lll}
\hline $\mathrm{K}_{\mathrm{d}}$ & Peak Dose $(\mathrm{mrem} / \mathrm{yr})$ & Time of Peak Dose \\
\hline 0.1 & 26.6 & 2250 \\
0.5 & 14.9 & 2670 \\
1.5 & 9.65 & 4150 \\
\hline
\end{tabular}

\subsubsection{Model Sensitivity to Infiltration Rate}

It has generally been assumed that by reducing the net infiltration, the subsequent groundwater dose would be reduced. The effect was simulated by reducing the spatially variable infiltration inside the SDA from the averaged $8.5 \mathrm{~cm} / \mathrm{yr}$ to $1 \mathrm{~cm} / \mathrm{yr}$. This change occurred in the year 2002, 50 yrs after disposals started at the SDA. The inventory used in these simulations was the upper-bound CIDRA estimate. The doses for Am-241, Np-237, and U-238 were simulated. The results are shown in Figures 5-4, 5-5 and 5-6 below.

As expected the Am-241 groundwater dose was greatly reduced (Figure 5-4) from 0.16 mrem/yr with an infiltration rate of $8.5 \mathrm{~cm} / \mathrm{yr}$ to $0.06 \mathrm{mrem} / \mathrm{yr}$ with an infiltration rate of $1 \mathrm{~cm} / \mathrm{yr}$. An unexpected result was that the peak groundwater dose for Np-237 and U-238 actually remained the same or increased slightly with the reduced infiltration rate (Figures 5-5 and 5-6). The Np-237 

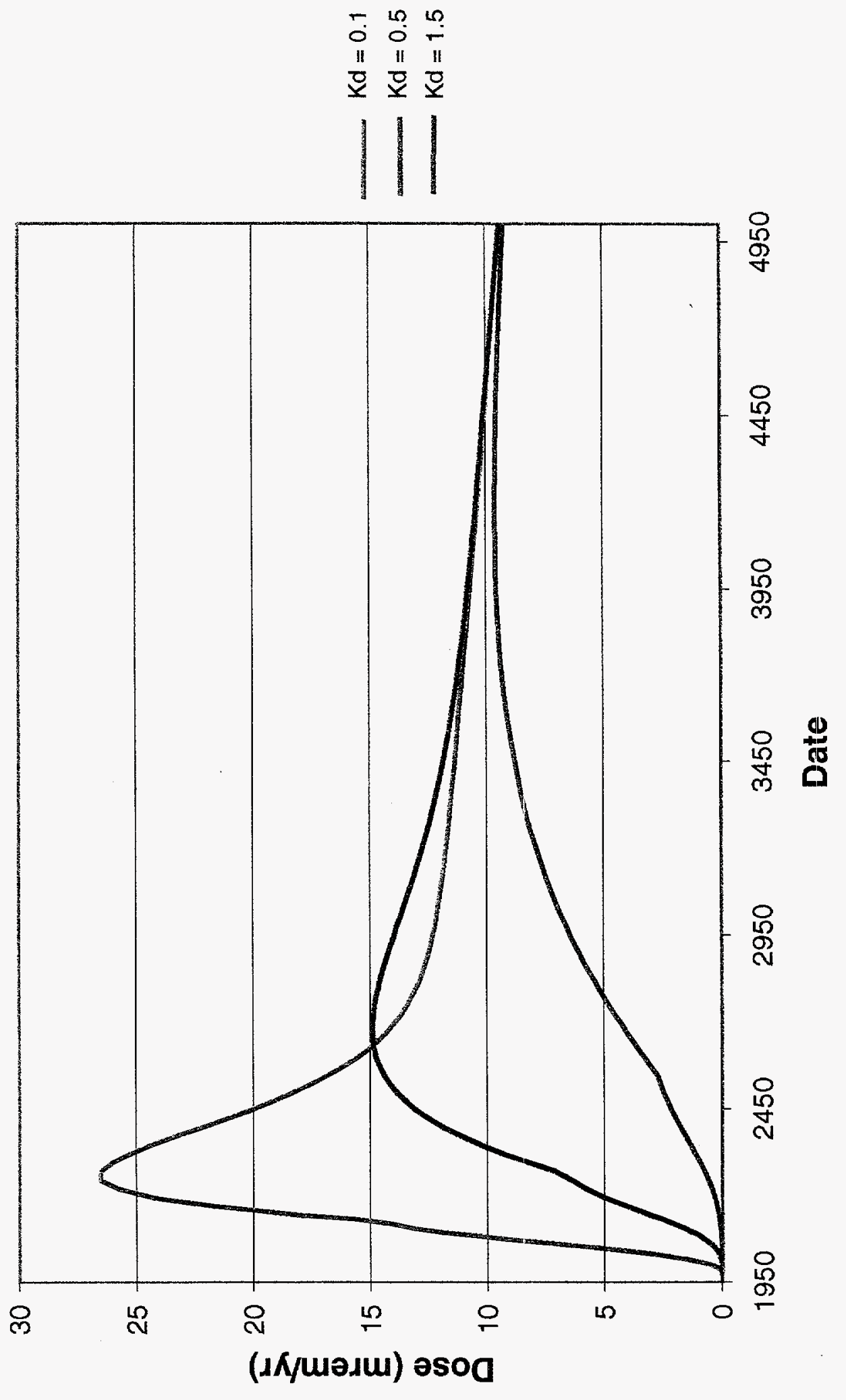

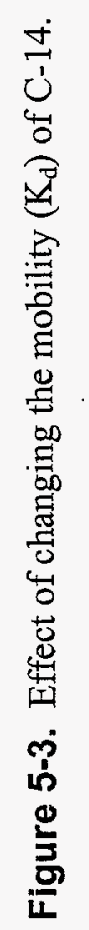




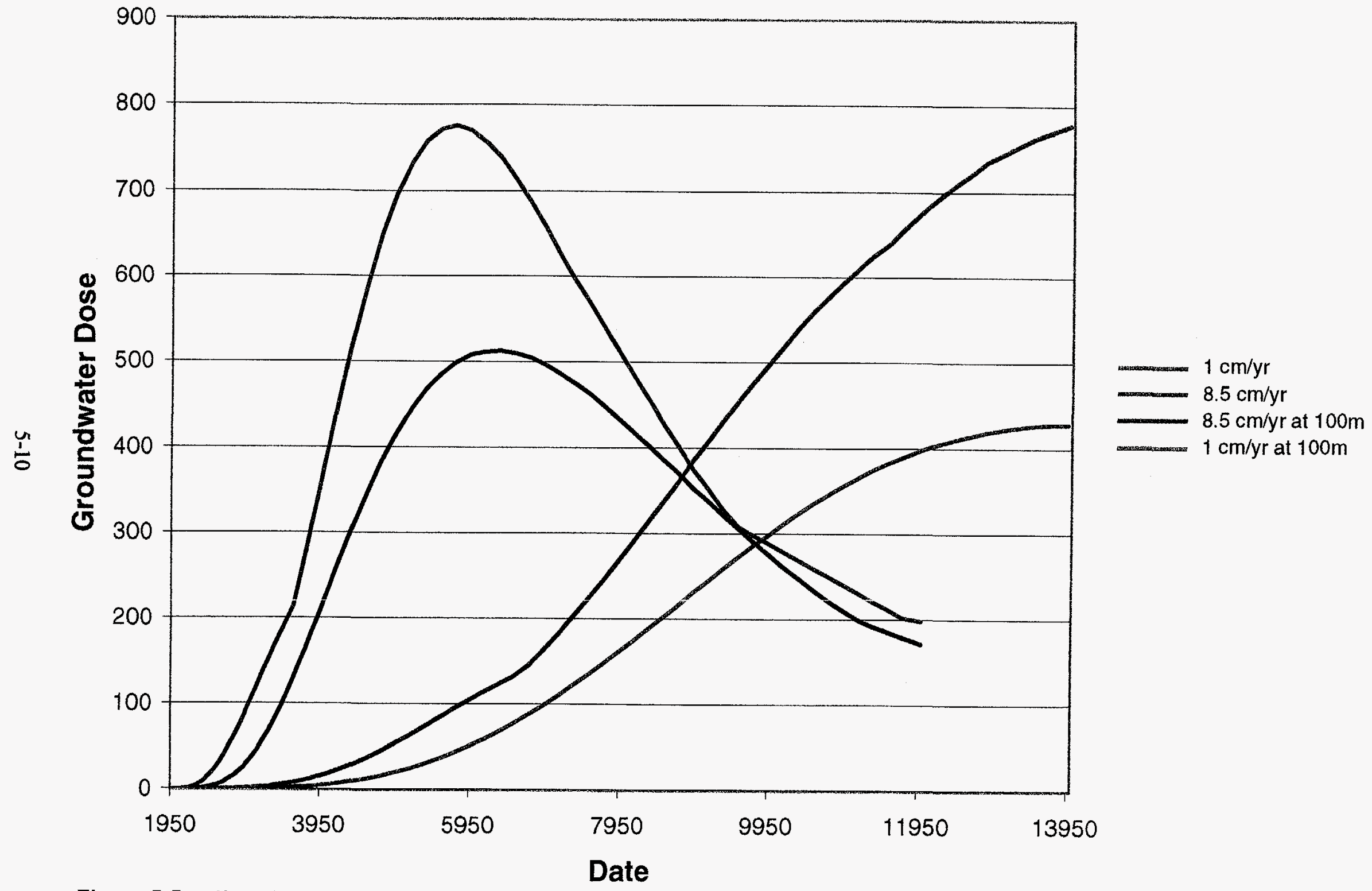

Figure 5-5. Effect of changing infiltration rate on Np-237. 


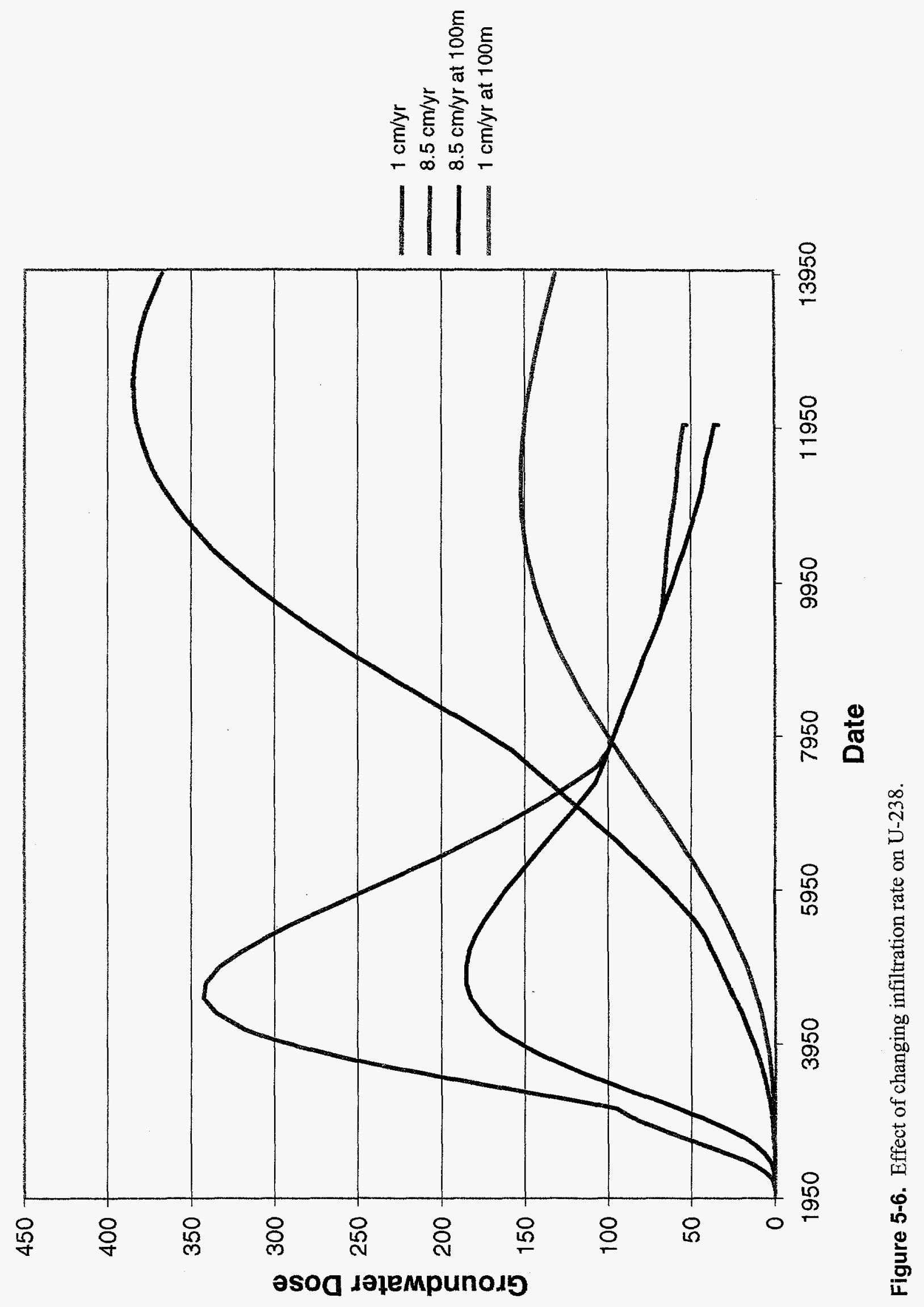


groundwater dose stayed at $780 \mathrm{mrem} / \mathrm{yr}$ with the reduced infiltration rate. The U-238 groundwater dose increased from 343 to $385 \mathrm{mrem} / \mathrm{yr}$. As expected, the times at which the peak occurred were later with the reduced infiltration rate.

Overall, the concentrations and doses are higher at the later times in the reduced infiltration simulation because there is less horizontal spreading during the transit of the vadose zone and because the low permeability region beneath the southern half of the SDA allows for very little dilution in the aquifer. The infiltration outside the SDA was $1 \mathrm{~cm} / \mathrm{yr}$ and the infiltration inside the SDA averaged $8.5 \mathrm{~cm} / \mathrm{yr}$ for the base case. The additional water applied inside the SDA spreads laterally at the interbeds and consequently spreads the contaminant wider before reaching the aquifer. Since there is negligible decay due to the long half-lives of Np-237 and U-238, the same amount of mass eventually gets released in the reduced infiltration simulation. Even though this release is spread out over a longer period of time in the reduced infiltration simulation, without the additional spreading in the vadose zone the lower mass contribution to the aquifer is concentrated in a smaller area resulting in higher concentrations immediately beneath the SDA. Figure 5-7 illustrates this concentrating effect by showing contours of the concentration of U-238 in the vadose zone just above the aquifer. The contour levels portrayed for each plot are the same and are logarithmic from 1 to $1,000 \mathrm{pCi} / \mathrm{L}$ and in increments of $1,000 \mathrm{pCi} / \mathrm{L}$ above $1,000 \mathrm{pCi} / \mathrm{L}$. The simulation time represented in Figure 5-7 corresponds to the time when the peak aquifer concentration occurred for both the base case and reduced infiltration simulations.

From the two vadose zone concentration maps in Figure 5-7, it can be seen that the mass flux would be less in the low infiltration case since the amount of water passing into the aquifer is less by about a factor of eight and the peak concentrations are only about a factor of one and a half greater. The average linear velocity (seepage velocity) within the low permeability region is on the order of $1 \mathrm{~m} / \mathrm{yr}$. This allows the concentration within the low permeability region to be dominated by the concentration of the water influxing from the vadose zone. If there were no low permeability zone, the concentrations in the aquifer would always be less under low infiltration rates. This latter point is made as a caution in interpreting the results in the section.

Since the net flux is lower with the reduced infiltration, the peak at downgradient locations should be lower with the reduced infiltration. Table 5-4 presents a comparison of the results at the peak and $100 \mathrm{~m}(328 \mathrm{ft})$ downgradient both with and without the reduced infiltration. As can be seen, reduced infiltration causes the peak dose at both locations to be later in time and the risks at $100 \mathrm{~m} 328 \mathrm{ft}$ ) downgradient are also reduced. The results also show that the estimated amounts of water currently infiltrating inside and outside the SDA have important impacts on the predictive simulation results. If the average amount of water that infiltrates through the SDA is actually less than $8.5 \mathrm{~cm} / \mathrm{yr}$, the impact of reducing infiltration rates on reducing future risks from $\mathrm{Np}-237$ and U-238 would be greater. Lastly, the subsurface transport model that was used in this simulation was only partially calibrated. The degree to which the model actually represents the SDA has not been demonstrated. The results are applicable only in their relation to the base case simulation. 
Base case:

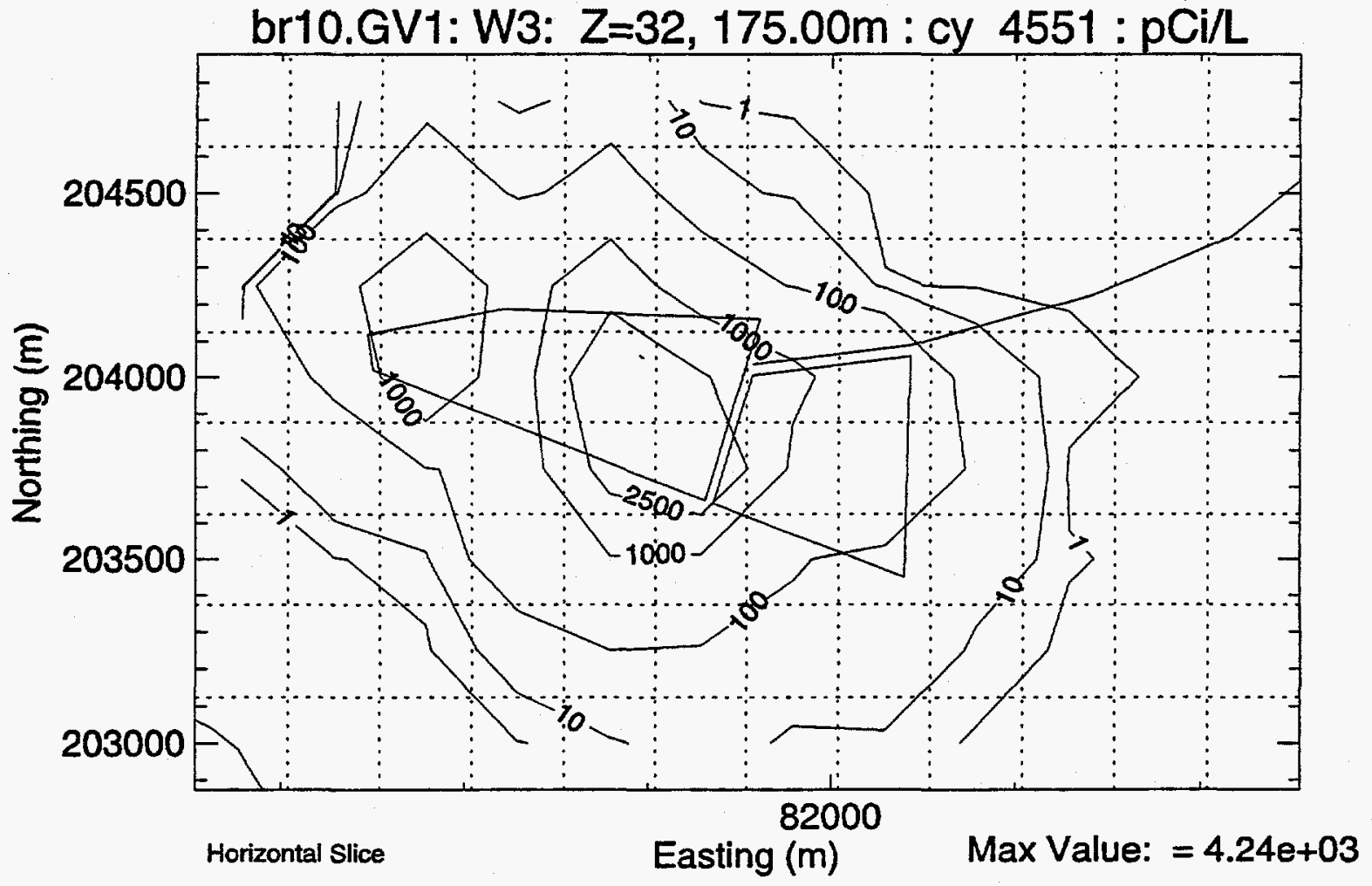

Low infiltration case:

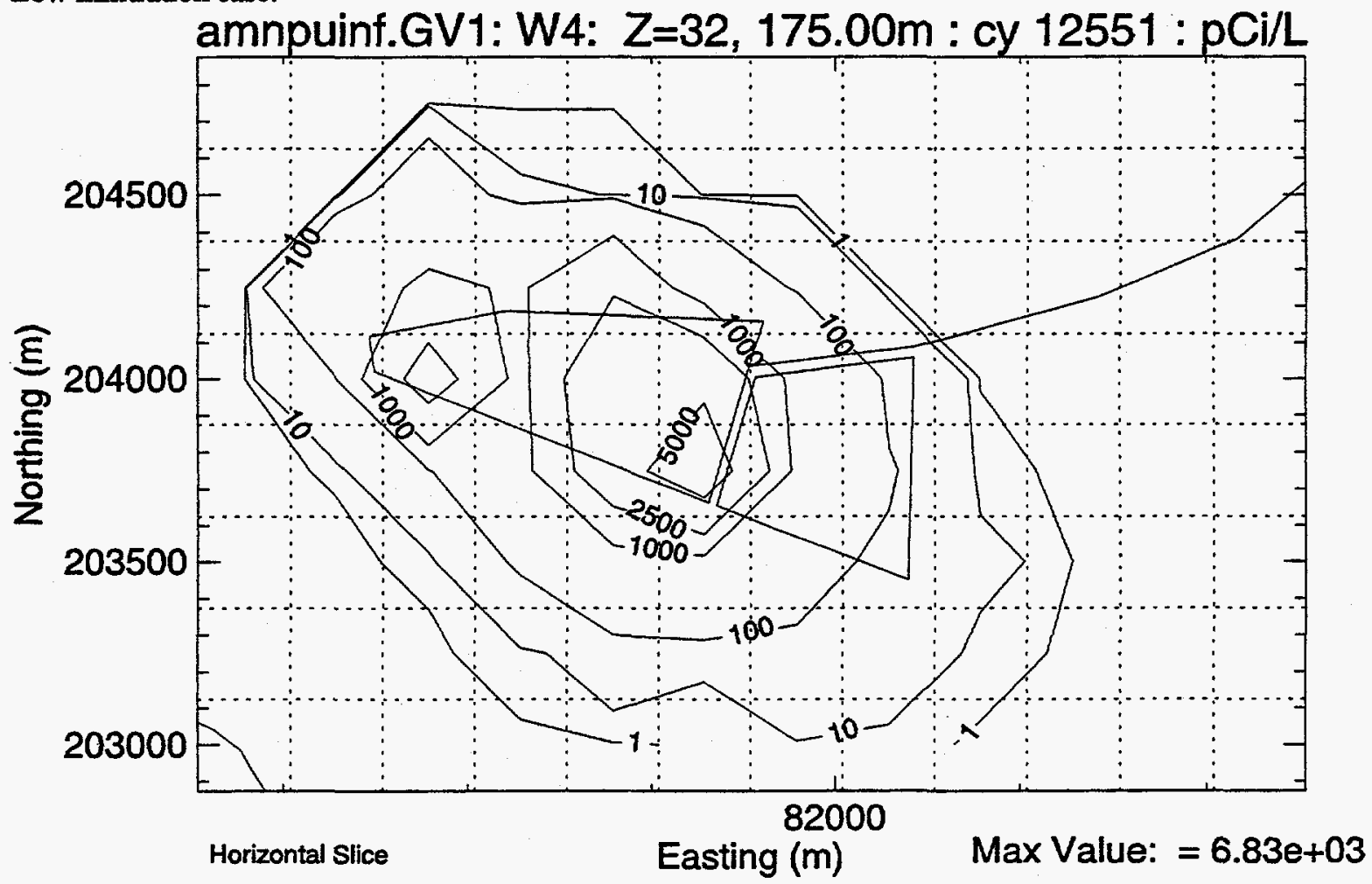

Figure 5-7. Simulated U-238 concentrations $(\mathrm{pCi} / \mathrm{L})$ in the vadose zone immediately above the aquifer for the base and reduced infiltration cases. 
Table 5-4. Dose (mrem/yr) at two receptor locations for base and reduced infiltration cases.

\begin{tabular}{|c|c|c|c|c|}
\hline & \multicolumn{2}{|c|}{ Base case $(8.5 \mathrm{~cm} / \mathrm{yr})$} & \multicolumn{2}{|c|}{ Reduced infiltration $(1 \mathrm{~cm} / \mathrm{yr})$} \\
\hline & $\mathrm{Np}-237$ & $\mathrm{U}-238$ & $\mathrm{~Np}-237$ & U-238 \\
\hline Peak groundwater dose at peak location & 776 & 343 & 778 & 385 \\
\hline Time of peak dose at peak location (yr) & 5755 & 4554 & 13960 & 12560 \\
\hline Peak groundwater dose at $100 \mathrm{~m}$ & 513 & 185 & 428 & 152 \\
\hline Time of peak dose at $100 \mathrm{~m}(\mathrm{yr})$ & 6355 & 4,850 & 13960 & 11250 \\
\hline \multicolumn{5}{|c|}{$\begin{array}{l}\text { The values use upper-bound estimates of the waste inventory and were nun for the RWMC-IRA so the relative dloses are } \\
\text { of interest but the absolute values are unrelated to the Composite Analysis. }\end{array}$} \\
\hline
\end{tabular}

\subsubsection{Model Sensitivity to Contaminant Phase}

The simulations presented for Section 5.2.1 only considered aqueous phase transport of C14. Carbon-14 can and does partition into the gaseous or vapor phase. This sensitivity simulation considered the effect of including vapor-phase transport in addition to aqueous-phase transport. The dual-phase flow and transport simulation model from Magnuson and Sondrup (1998) was used. The dual phase simulations were done using the CIDRA best-estimate inventory data. Because of the long simulation times, the dual-phase simulations were not rerun for the new CA inventory. Figure 5-8 shows the predicted doses when vapor-phase transport was included. The same $\mathrm{C}-14 \mathrm{~K}_{d}$ values as the single-phase simulations in Case 5 were used. Also shown in the figure are the corresponding single-phase simulation results from Case 5. With the inclusion of vapor-phase transport, several results were observed. Transport through diffusion in the vaporphase can occur more rapidly than in the dissolved phase leading to higher concentrations and doses occurring in the aquifer sooner than in the single-phase simulations. There is also a loss of C-14 by diffusion to the atmosphere at the upper boundary of the dual-phase simulation. This results in lower overall maximum C-14 concentrations and risks in the aquifer than the corresponding single-phase C-14 simulations. Figure 5-9 illustrates the percentage of C-14 mass that escapes through the upper surface atmospheric boundary. Table 5-5 summarizes the data for this case.

\subsubsection{Model Sensitivity to Steel Corrosion Rate}

This sensitivity simulation used the best-estimate C-14 inventory from CIDRA (1.29E+04 Ci). Table 5-6 shows a comparison of the doses predicted for C-14 with two different corrosion rates. The corrosion rates are shown as a fractional release rate. The first fractional release rate of 1.0E-05 came from the IRA and used older less conservative stainless steel corrosion rates and a different surface area to volume ratio. The higher fractional release rate of 4.17E-04 was used in the PA and is based on the IMPACTS methodology. Figure 5-10 shows the groundwater ingestion doses predicted for these two cases. Comparisons to the doses computed with the higher corrosion rate show the substantial effect of changing the corrosion rate. Changing the corrosion rate by a factor of 40 changes the dose by a factor of 10 . This illustrates that changing the release rate can have a non-linear effect on dose depending on which waste forms are changed.

\subsubsection{Model Sensitivity Analysis Conclusions}

The sensitivity simulations shown in this section illustrate a large degree of responses in the predicted simulation results to changes in mobility, infiltration, or transport phases. These 


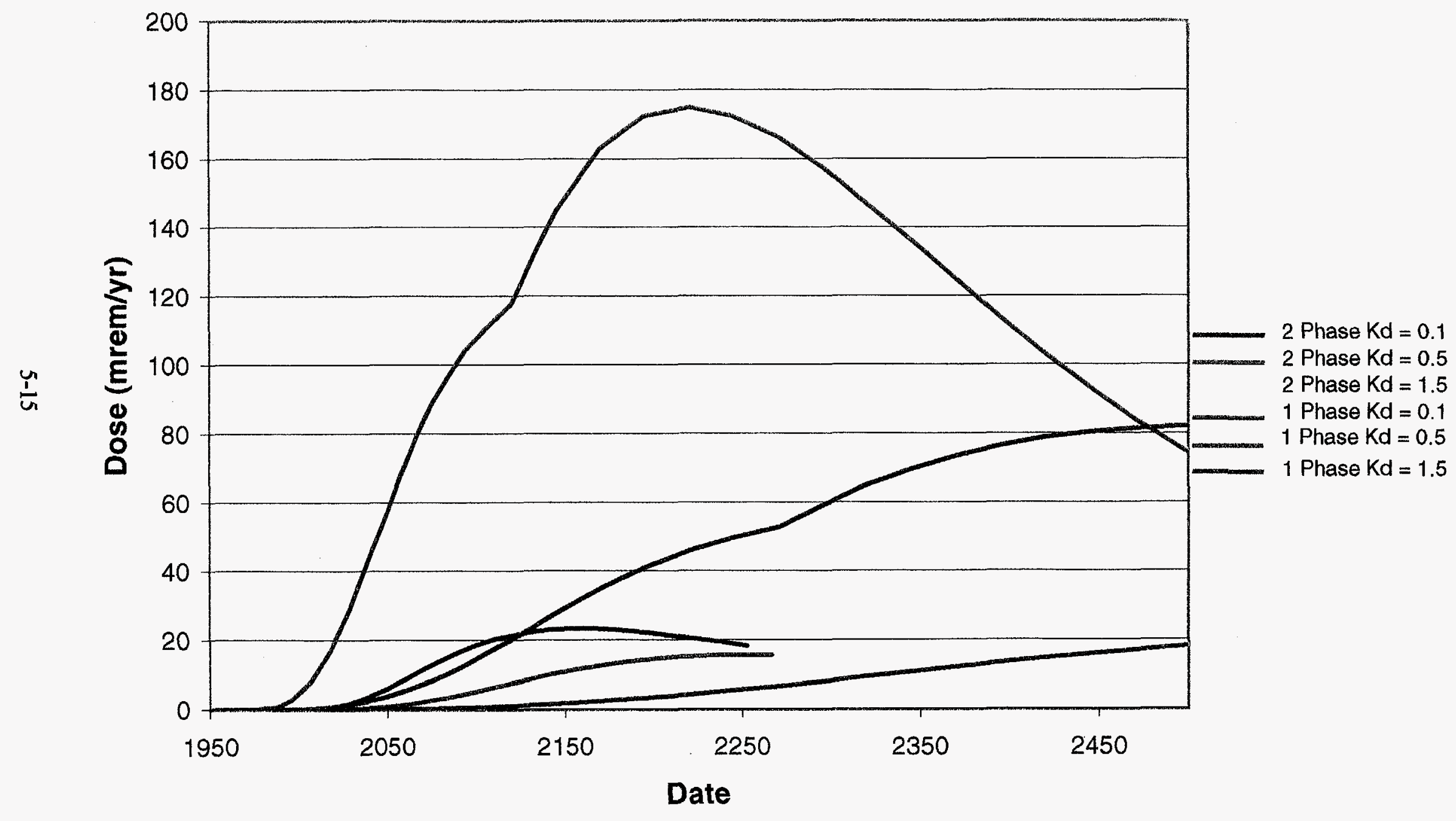

Figure 5-8. Effect of two-phase transport on C-14. 
Total C-14 Source Release

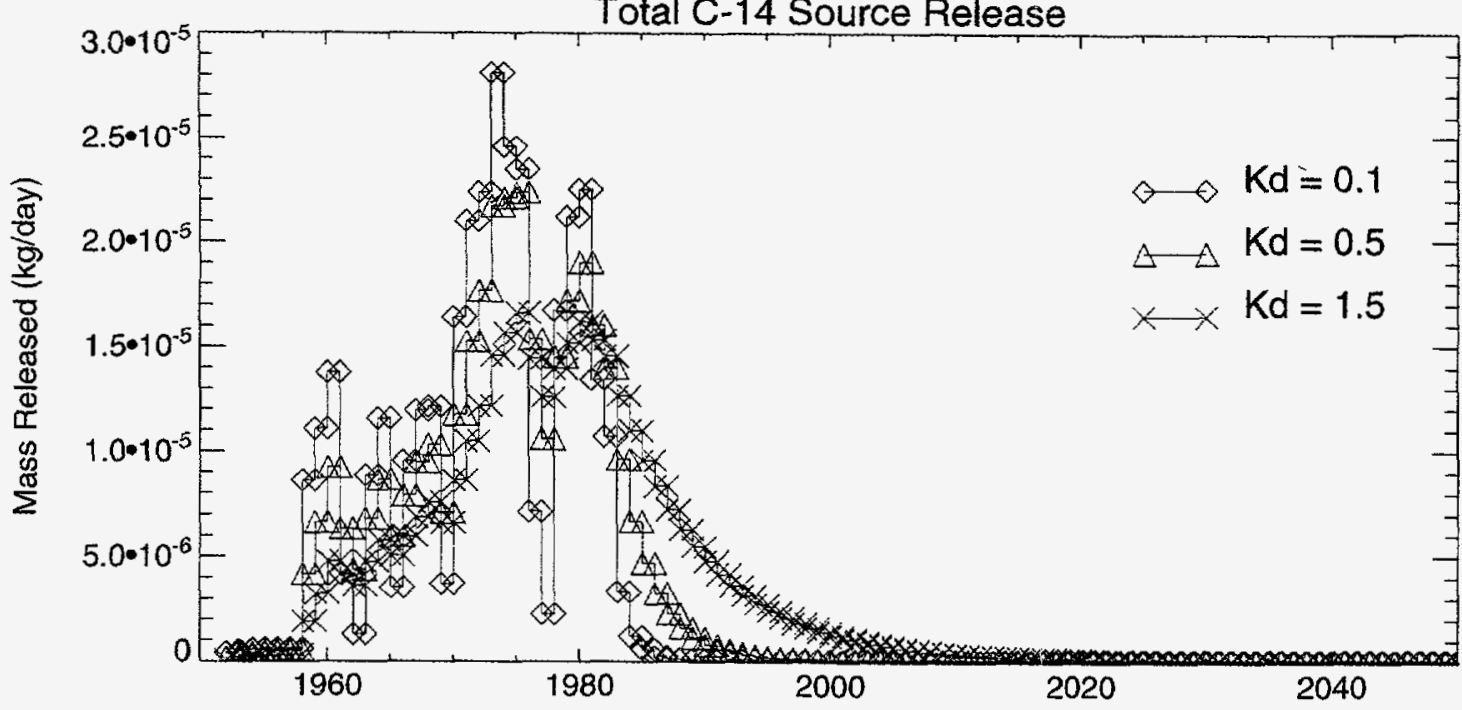

Flux of C-14 Through Surface
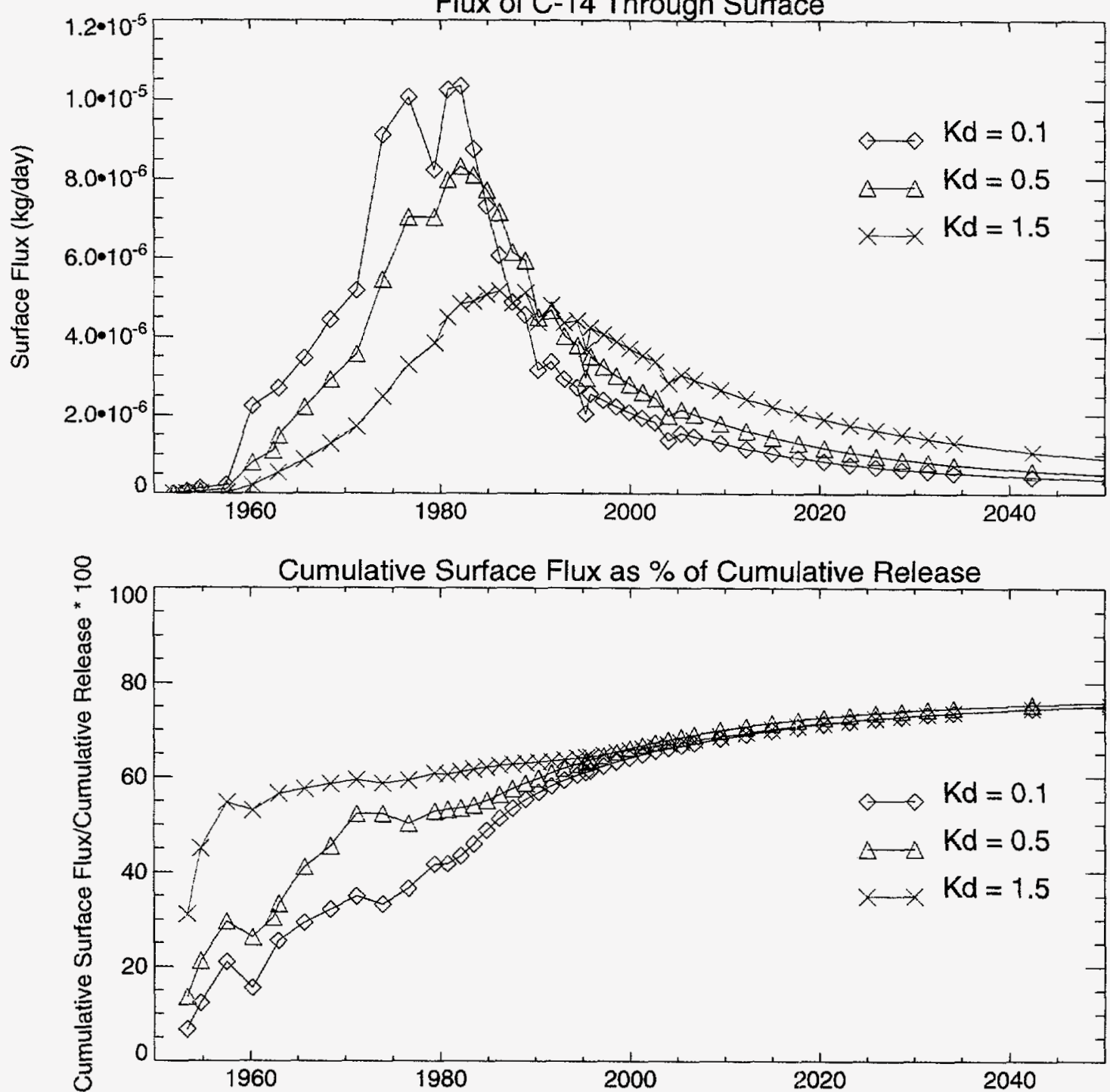

Figure 5-9. Carbon-14 source releases, surface fluxes, and cumulative surface fluxes as a percentage of cumulative source releases for a range of partition coefficients in two-phase simulations. 
Table 5-5. Comparison of the single-phase C-14 doses to the dual-phase C-14 doses.

\begin{tabular}{llll}
\hline Best-estimate Inventory & $\mathrm{K}_{\mathrm{d}}$ & Peak Dose $(\mathrm{mrem} / \mathrm{yr})$ & Time of Peak Dose \\
\hline Single-phase & 0.1 & 175 & 2220 \\
& 0.5 & 82 & 2500 \\
& 1.5 & 36.3 & 3190 \\
Dual-phase & 0.1 & 23.4 & 2160 \\
& 0.5 & 15.7 & 2250 \\
& 1.5 & 6.89 & 2340 \\
\hline
\end{tabular}

Table 5-6. Sensitivity to steel corrosion rate.

\begin{tabular}{cccc}
\hline $\begin{array}{c}\text { Fractional release rate } \\
\text { from steels } \\
\left(\mathrm{yr}^{-1}\right)\end{array}$ & $\begin{array}{c}\text { Max concentration } \\
(\mathrm{pCi} / \mathrm{L})\end{array}$ & $\begin{array}{c}\text { Max groundwater } \\
\text { ingestion dose } \\
(\mathrm{mrem} / \mathrm{yr})\end{array}$ & $\begin{array}{c}\text { Max all pathways dose } \\
(\mathrm{mrem} / \mathrm{yr})\end{array}$ \\
\hline $1.00 \mathrm{E}-05$ & $4.86 \mathrm{E}+03$ & 7.15 & 287 \\
$4.17 \mathrm{E}-04$ & $4.43 \mathrm{E}+04$ & 65.2 & 261 \\
\hline
\end{tabular}

results point to the need for continued monitoring of water and contaminant behavior in order to determine whether the predicted simulation results are representative of the field situation. By selecting contaminants that are expected to change in the short term according to the model predictions, and then monitoring for those contaminants, confidence in the overall appropriateness of the model can be improved. 


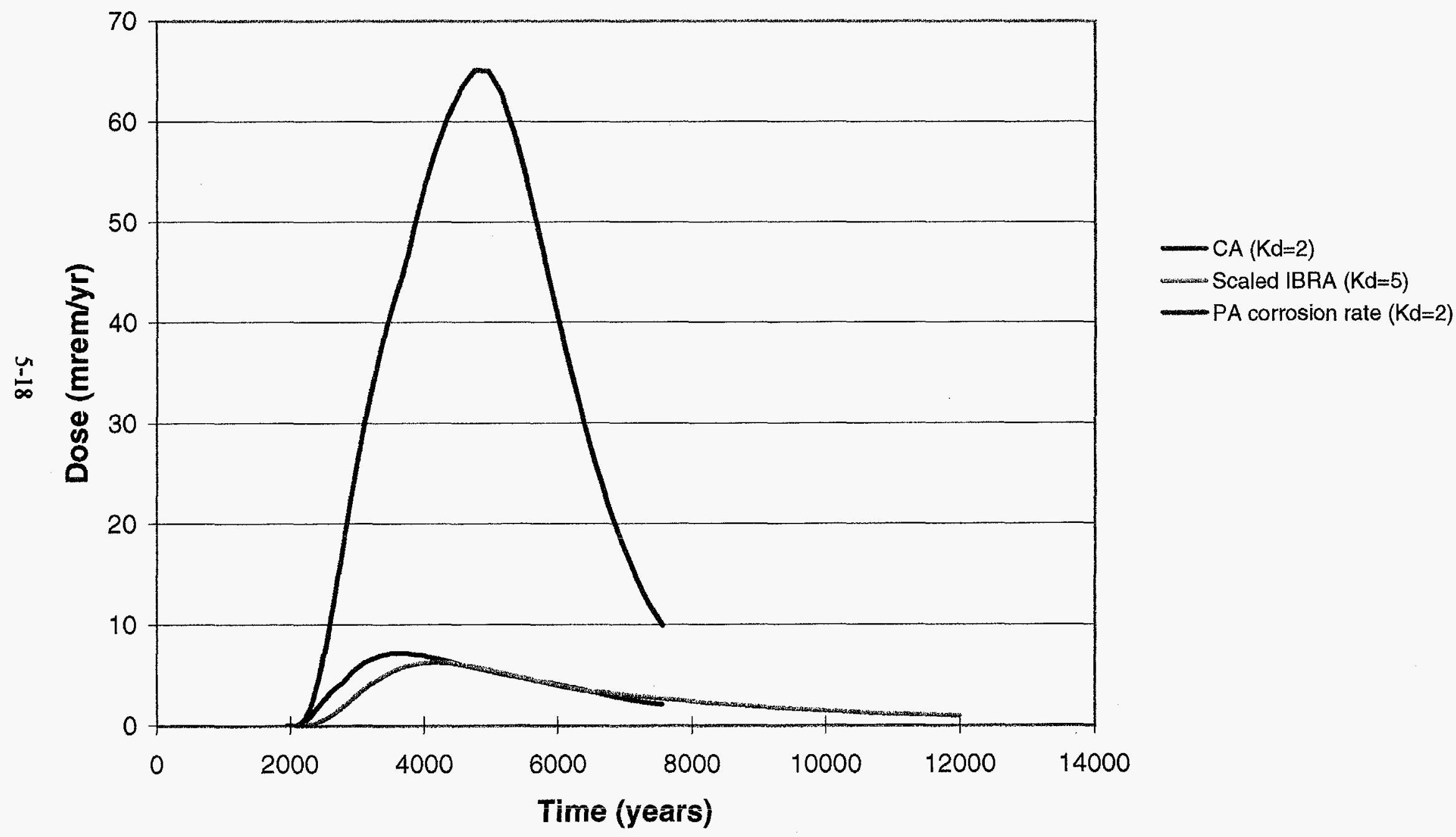

Figure 5-10. Effect of steel corrosion rate on C-14 dose. 


\section{RESULTS}

In this section the total calculated dose to a hypothetical future member of the public is compared to the DOE primary dose limit of $100 \mathrm{mrem} / \mathrm{yr}$, the composite analysis dose constraint of $30 \mathrm{mrem} / \mathrm{yr}$ as defined in Section 3.5 of the Composite Analysis Guidance document (DOE, 1996), and the site-specific groundwater protection performance objectives as defined in the RWMC PA and Addendum (Maheras et al., 1994 and Maheras et al., 1997). The prediction of a potential dose to a hypothetical future member of the public that exceeds the primary dose in the near future may constitute a present-day noncompliance. The prediction of a potential dose to a hypothetical future member of the public that exceeds the primary dose at a time far in the future identifies a potential future problem that must be mitigated or corrected before it occurs. The Options Analysis, ALARA process, and sometimes the best available technology (BAT) process are used in the selection of mitigative actions or controls.

In this section, the total calculated dose for a hypothetical future member of the public and predicted future groundwater concentrations are compared to the following constraints:

- The DOE primary dose limit of $100 \mathrm{mrem} / \mathrm{yr}$.

- The DOE dose constraint of $30 \mathrm{mrem} / \mathrm{yr}$. If the base case dose exceeds $30 \mathrm{mrem}$ in a year, an options analysis must be completed.

- The groundwater ingestion dose limit or MCL of $4 \mathrm{mrem} / \mathrm{yr}$ for beta-gamma emitting man-made radionuclides.

- The drinking water standard MCL of $15 \mathrm{pCi} / \mathrm{L}$ for alpha emitting radionuclides (which includes $\mathbf{R a - 2 2 6}$ activity and gross alpha particle activity excluding $\mathbf{R n}$ and $\mathbf{U}$ ).

- The drinking water standard MCL of $5 \mathrm{pCi} / \mathrm{L}$ for $\mathrm{Ra}-226$ plus $\mathrm{Ra}-228$ activity.

- The drinking water standard MCL of $8 \mathrm{pCi} / \mathrm{L}$ for Sr-90 activity.

- The drinking water standard $\mathrm{MCL}$ of $20,000 \mathrm{pCi} / \mathrm{L}$ for $\mathrm{H}-3$ (tritium) activity.

- The proposed drinking water standard MCL of $20 \mu \mathrm{g} / \mathrm{L}$ for uranium.

The PA (Maheras et al., 1994 and 1997) estimated doses for the atmospheric, intruder, groundwater protection, and all-pathways scenarios. Of these, the atmospheric and intruder scenarios are assumed to be near field scenarios and not required to be reevaluated for the Composite Analysis. Therefore, the Composite Analysis only calculates doses for the all-pathways and groundwater protection scenarios.

\subsection{All-Pathways and Groundwater Protection}

The predicted all-pathways and groundwater dose to a hypothetical future member of the public are compared to the dose constraints described above for the following three time periods:

- operational and institutional control period - present until the year 2120 at the INEEL boundary. 
- post-institutional control compliance period for approximately 1,000 years from 2120 until the year $3000,100 \mathrm{~m}$ ( $328 \mathrm{ft})$ from the RWMC boundary.

- post-institutional control period - year 2120 until the year of the peak concentration or a maximum of 10,000 years into the future, $100 \mathrm{~m}$ (328) from the RWMC boundary.

A comparison of the results with the performance objectives for the all-pathways and groundwater protection scenarios are given in Table 6-1. The all-pathways comparisons are required for the Composite Analysis (DOE, 1996) and the groundwater protection comparisons are provided as additional information.

During the operational and institutional control periods, the public receptor is located at the INEEL Site boundary. As shown in Table 6-1, the all-pathways dose through groundwater for the public receptor is estimated to be $0.23 \mathrm{mrem} / \mathrm{yr}$, less than $0.23 \%$ of the $100 \mathrm{mrem} / \mathrm{yr}$ standard and $0.77 \%$ of the 30 mrem/yr standard. For the all-pathways dose, I-129, C-14, Cl-36, U-234, U-238, and Np-237 were the primary radionuclides of concern. The predicted radionuclide concentrations and associated peak doses are all below the groundwater protection performance objectives. No radionuclides are expected to provide an unacceptable dose in the aquifer during the operational and institutional control periods.

During the post-institutional control period, the public receptor is located $100 \mathrm{~m}$ (328) from the SDA boundary. As shown in Table 6-1, the peak all-pathways dose through groundwater is estimated to be 58 mrem/yr between the years 2160 and 3000 . By the year 6000 , the all-pathways dose is predicted to rise to $340 \mathrm{mrem} / \mathrm{yr}$. In the year 3000 , the primary contributors to the all-pathway dose are C-14 (21\%), U-238 (31\%), Np-237 (25\%), and U-234 (20\%). At the time of the peak dose after the year 3000, the primary dose contributors are predicted to be Np-237 (63\%), U-238 (21\%), and U-234 (10\%).

With respect to the groundwater protection objectives, the predicted concentrations and associated doses after the institutional control period are summarized below:

- The predicted dose from man-made beta-gamma are $9.68 \mathrm{mrem} / \mathrm{yr}$ prior to the year 3000 . This value is $142 \%$ larger than the $4 \mathrm{mrem} / \mathrm{yr}$ MCL. The primary contributors to the man-made betagamma dose are C-14 and I-129.

- The predicted peak H-3 concentration after year 2120 is $515 \mathrm{pCi} / \mathrm{L}$ which is $2.5 \%$ of the $20,000 \mathrm{pCi} / \mathrm{L} \mathrm{MCL}$.

- The predicted peak Sr-90 concentration after year 2120 is $1.7 \mathrm{E}-03 \mathrm{pCi} / \mathrm{L}$ which is $0.02 \%$ of the $8 \mathrm{pCi} / \mathrm{L} \mathrm{MCL}$.

- The predicted peak $\mathrm{Ra}-226$ and $\mathrm{Ra}-228$ concentrations are $3.2 \mathrm{E}-04 \mathrm{pCi} / \mathrm{L}$ prior to the year 3000 and $0.12 \mathrm{pCi} / \mathrm{L}$ in the year 12,000 . These values are $0.006 \%$ and $2.4 \%$ of the $5 \mathrm{pCi} / \mathrm{L} \mathrm{MCL}$. The concentration is still rising in the year 12,000 at the end of the simulation period.

- The predicted peak gross alpha concentrations are $5.1 \mathrm{pCi} / \mathrm{L}$ prior to the year 3000 and $81 \mathrm{pCi} / \mathrm{L}$ at the time of the peak concentration (about year 6000 ). These values are $34 \%$ and $540 \%$ of the $15 \mathrm{pCi} / \mathrm{L} \mathrm{MCL}$. The primary contributor to the gross alpha concentrations is Np-237 which contributes more than $97 \%$ of the activity.

- The predicted peak uranium concentrations are $261 \mu \mathrm{g} / \mathrm{L}$ prior to the year 3000 and $1,170 \mu \mathrm{g} / \mathrm{L}$ at the time of the peak concentration (about the year 5000). These values are 13 times and 58 times the $20 \mu \mathrm{g} / \mathrm{L}$ MCL. 


\section{0}

Table 6-1. Comparison of results with performance objectives for all-pathways and groundwater protection.

\begin{tabular}{|c|c|c|c|c|}
\hline Performance objective & Regulatory reference & $\begin{array}{l}\text { Operational and institutional } \\
\text { control periods" }\end{array}$ & $\begin{array}{l}\text { Post-institutional control } \\
\text { period until the year } 3000^{\circ}\end{array}$ & $\begin{array}{l}\text { Post-institutional control } \\
\text { period until the year } 12,000\end{array}$ \\
\hline $\begin{array}{l}100 \mathrm{mrem} / \mathrm{yr} \text { (DOE primary dose limit) and } \\
30 \text { mrem/yr (CA dose limit for Options Analysis) }\end{array}$ & All-pathways ${ }^{c}$ & $0.23 \mathrm{mrem} / \mathrm{yr}$ & $58 \mathrm{mrem} / \mathrm{yr}$ & $340 \mathrm{mrem} / \mathrm{yr}$ \\
\hline 4 mrem/yr man-made beta-gamma EDE & Groundwater protection ${ }^{\mathbf{C}}$ & $0.06 \mathrm{mrem} / \mathrm{yr}$ & $9.7 \mathrm{mrem} / \mathrm{yr}$ & $9.7 \mathrm{mrem} / \mathrm{yr}$ \\
\hline $20,000 \mathrm{pC} / \mathrm{L} / \mathrm{H}-3$ concentration & Groundwater protection & $6.5 \mathrm{pCi} / \mathrm{L}$ & $515 \mathrm{pCi} / \mathrm{L}$ & $515 \mathrm{pCi} / \mathrm{L}$ \\
\hline $8 \mathrm{pCi} / \mathrm{L} \mathrm{Sr}-90$ concentration & Groundwater protection ${ }^{8}$ & $4.9 \mathrm{E}-5 \mathrm{pCi} / \mathrm{L}$ & $1.7 \mathrm{E}-3 \mathrm{pCi} / \mathrm{L}$ & $1.7 \mathrm{E}-3 \mathrm{pCi} \Omega$ \\
\hline $5 \mathrm{pCi} / \mathrm{La}-226$ and Ra-228 concentration & Groundwater protection & 3.5E-8 pCi/L & 3.2E-4 pCi/L & $0.12 \mathrm{pCi} / \mathrm{L}$ \\
\hline $15 \mathrm{pC} / \mathrm{L}$ gross alpha concentration & Groundwater protection ${ }^{4}$ & $6.0 \mathrm{E}-4 \mathrm{pCi} / \mathrm{L}$ & $5.1 \mathrm{pCil}$ & $81 \mathrm{pCi} / \mathrm{L}$ \\
\hline $20 \mu \mathrm{g} / \mathrm{L}$ uranium concentration & Groundwater protection & $0.03 \mu g / L$ & $261 \mu \mathrm{g} / \mathrm{L}$ & $1,170 \mu \mathrm{g} / \mathrm{L}$ \\
\hline $\begin{array}{l}\text { a. During the operational and institutional control pe } \\
\text { b. During the post-institutional control period, from } 2 \\
\text { c. From the Composite Analysis Guidance Documen } \\
\text { d. Derived from current and proposed MCLs. }\end{array}$ & $\begin{array}{l}\text { ls, from } 1984 \text { to } 2120 \text {, the re } \\
0 \text { to the time of peak impact, } \\
\text { OE, } 1996 .\end{array}$ & $\begin{array}{l}\text { is at the INEEL Site boundary. } \\
\text { ceptor is } 100 \mathrm{~m} \text { from the SDAt }\end{array}$ & ndary. & \\
\hline
\end{tabular}


During the post institutional control period, prior to the year 3000, the all pathways dose is less than the DOE primary dose limit of $100 \mathrm{mrem} / \mathrm{yr}$ but greater than the CA dose limit of $30 \mathrm{mrem} / \mathrm{yr}$ requiring an options analysis. In addition the predicted man-made beta-gamma dose is slightly over the MCL and the uranium concentrations are significantly over the MCL. Uranium is the primary radionuclide contributing to groundwater concentrations that exceed the performance objectives.

After the year 3000, the predicted concentrations increase for some of the radionuclides exceeding the all-pathways and some groundwater protection objectives. The largest all-pathways and beta-gamma doses, as well as $\mathrm{Ra}-226, \mathrm{Ra}-228$, gross alpha, and uranium concentrations, are predicted to occur after the year 3000 . In the long term, the primary concentration and dose contributors are $\mathrm{Np}-237$, and the uraniums.

\subsection{Summary}

The cumulative annual dose to a hypothetical member of the public over the $1,000 \mathrm{yrs}$ following closure of the active LLW facility from the active facility itself and all other INEEL radioactive sources that could interact with the LLW facility is $58 \mathrm{mrem} / \mathrm{yr}$. This dose is below the DOE primary dose limit of $100 \mathrm{mrem} / \mathrm{yr}$ but above the $30 \mathrm{mrem} / \mathrm{yr}$ dose constraint. Since the projected dose exceeds the $30 \mathrm{mrem}$ annual dose constraint an Options Analysis was prepared to consider the actions that could be taken to reduce the calculated dose and to consider the costs of those actions. 


\section{OPTIONS ANALYSIS}

This chapter describes an Options Analysis conducted to determine the feasibility of ways to reduce the projected annual dose to members of the public that might be exposed to radioactive contaminants from the RWMC. It also presents an As Low As Reasonably Achievable (ALARA) analysis.

Three options for creating a reduction in annual dose were considered: (1) lowering infiltration of precipitation through the waste by providing a better cover, (2) maintaining control over the RWMC and portions of the INEEL indefinitely, and (3) extending the period of institutional control beyond the $100 \mathrm{yrs}$ assumed in the Composite Analysis.

Of the three options investigated, only maintaining control over the RWMC and a small part of the present INEEL appears to be feasible and cost effective. Improving the cover over the waste to reduce infiltration of precipitation is too expensive to be cost effective according to the Composite Analysis guidelines provided by DOE. In order to be of practical value, extending the duration of institutional control becomes indistinguishable from the option that involves maintaining control over a portion of the site indefinitely.

\subsection{INTRODUCTION}

The Composite Analysis is an assessment of the cumulative impacts from the active LLW disposal facility, and from all other sources of radioactive contamination that could interact with possible releases from the LLW disposal facility in causing a dose to future members of the public. The highest projected annual dose over the 1,000 yrs following closure of the active facility to a hypothetical member of the public from all INEEL sources that could interact in that manner is reported in Section 6 to be about 58 mrem/yr. This dose was compared with the dose constraint in the Composite Analysis guidance of 30 mrem/yr. Since the projected dose exceeds this constraint, an Options Analysis was prepared to consider the actions that could reasonably be taken to reduce the projected dose.

\subsection{OPTIONS ANALYSIS METHODOLOGY}

The Composite Analysis results described in Section 6 were calculated using the TETRAD threedimensional, multi-component, multi-phase fate and transport simulation. Data preparation and use of TETRAD involved a very high level of detail. For the Options Analysis, a simpler computer code was necessary, given the many sets of computer runs that are needed. The Options Analysis was conducted using the Environmental Protection Agency (EPA) PATHRAE-EPA one-dimensional multi-pathway fate and transport code (Merrell et al., 1995). PATHRAE assesses the annual dose to specified human receptors resulting from waste disposal in a near-surface facility. EPA has used PATHRAE to support rulemaking for the management and disposal of LLW.

The Options Analysis only focused on annual doses from the groundwater pathway (i.e., doses from domestic and agricultural uses of groundwater), as did the Composite Analysis, and only from the ten radionuclides that contributed the ten highest peak values to annual doses to the public. This approach is considered to be valid for comparing alternatives for dose reduction because the ten nuclides chosen contribute well over $99 \%$ of the dose, and the measures for reducing dose investigated in the Options 
Analysis (see Section 7.4) will probably reduce the doses from the nuclides that were not considered in the Options Analysis as well. Table 7-1 lists the radionuclides considered in the Options Analysis.

To ensure consistency between the detailed Composite Analysis and the Options Analysis, estimates of annual doses from the RWMC for the groundwater pathway generated by PATHRAE for the base case (no action to reduce projected peak doses below those in the Composite Analysis) were calibrated by comparing them to the projected doses from the RWMC that are reported in Section 6. PATHRAEcomputed annual doses at key points in time from groundwater ingestion from a well $100 \mathrm{~m} \mathrm{(328 \textrm {ft } )}$ downgradient from the RWMC and were compared to TETRAD estimates of those doses. The calibration was conducted for the radionuclides that are the four largest contributors to the projected annual dose within 1,000 yrs after the year 2020 , when the dose reaches the highest value during the $1,000 \mathrm{yr}$ period of interest. The four radionuclides are C-14, Np-237, U-234, and U-238. Good calibration with the projections from the Composite Analysis for Np-237, U-234, and U-238 were achieved at 500 yrs and 1,000 yrs. Input parameters for PATHRAE were adjusted as necessary, within the range of parameters used in the Composite Analysis, to match those two points in the time histories of doses from the important radionuclides.

The situation for C-14 was more complex because release of that radionuclide from the waste was modeled in the Composite Analysis using three different release models. Because only information about the aggregate dose rate from release of $\mathrm{C}-14$ from all sources was available from TETRAD, and because the history of that dose rate is complex, simple curve fitting such as that used for the other three important radionuclides was not possible. It was noted, however, that the aggregate dose rate curve is almost flat over the period 1,000 to 2,000 yrs, declining only slightly in time. Therefore, the dose rate for C-14 was assumed to be constant at the value calculated by TETRAD for a well $100 \mathrm{~m}(328 \mathrm{ft}$ ) from the edge of the waste at 1,000 yrs. Overall, results of the calibration showed that the three-dimensional TETRAD analysis could be approximated by PATHRAE over the 1,000 yr period of interest.

The same radionuclide release information and the ingestion dose conversion factors used in the Composite Analysis, presented in Tables 7-2 and 7-3 respectively, were used in the Options Analysis. The release rate information for $\mathrm{U}-234, \mathrm{U}-238$, and $\mathrm{Np}-237$ is based on distribution coefficient parameters $\left(\mathrm{K}_{\mathrm{d}}\right)$. The $K_{d}$ value indicates the ratio of contaminant in water in contact with the waste to contaminant in the waste. The effects of the infiltration rate on the amount of time water is assumed to be in contact with waste are also accounted for. The $K_{d}$ release model is representative of the transfer process, since $U-234$, $\mathrm{U}-238$, and Np-237 are generally released to the groundwater system as a result of surface washoff. Conversely, 91 percent of the C-14 is bound in the activated metal and beryllium block, which is released into the groundwater as a result of waste form corrosion. Since this release mechanism is generally independent of the infiltration rate, fixed release rates for C-14 of 1.2E-05 and 3.0E-04, respectively, were used in the Options Analysis. The remaining $\mathrm{C}-14$ is bound in resin, modeled with a $\mathrm{K}_{d}$ release of 0.1 $\mathrm{mL} / \mathrm{g}$.

Representative physical properties, resulting from PATHRAE calibration, are presented in Table 7-4. These include properties for the facility, vadose zone, and aquifer. Input parameters used in the Composite Analysis for aquifer dispersivity, cover thickness, waste thickness, distance to the well, infiltration rate, and average waste density were used in the Options Analysis without modification. However, the PATHRAE code can not accommodate the detailed spatial differences in vadose zone thickness, vadose zone porosity, vertical water velocity, aquifer velocity, and site dimensions as used in the Composite Analysis. Those ranges come from the considerable complexity of the individual structures in the vadose zone and the aquifer that cannot be represented by the PATHRAE code. For those parameters, 
Table 7-1. Radionuclides considered in the Options Analysis.

\begin{tabular}{cc}
\hline Radionuclide \\
\hline C-14 \\
Cl-36 \\
Tc-99 \\
I-129 \\
Ac-227 \\
Pa-231 \\
U-234 \\
U-235 \\
Np-237 \\
U-238 \\
\hline
\end{tabular}

Table 7-2. Radionuclide release model.

\begin{tabular}{|c|c|c|c|c|}
\hline Nuclide & Release Model & Release Model & $\begin{array}{c}\text { Release } \\
\mathrm{K}_{d} \\
(\mathrm{~mL} / \mathrm{g})\end{array}$ & $\begin{array}{c}\text { Parameter } \\
\text { Release Rate } \\
\left(\mathrm{yr}^{-1}\right)\end{array}$ \\
\hline C-14 & $\begin{array}{c}\text { Corrosion } \\
\text { Corrosion } \\
\text { Surface Washoff }\end{array}$ & $\begin{array}{c}\text { Release Rate } \\
\text { Release Rate } \\
\mathbf{K}_{\mathbf{d}}\end{array}$ & $\overline{-}$ & $\begin{array}{c}1.2 \mathrm{E}-05 \\
3.0 \mathrm{E}-04 \\
-\end{array}$ \\
\hline U-234 & Surface Washoff & $\mathbf{K}_{\mathbf{d}}$ & 6 & - \\
\hline U-238 & Surface Washoff & $\mathbf{K}_{\mathbf{d}}$ & 6 & - \\
\hline $\mathrm{Np}-237$ & Surface Washoff & $\mathbf{K}_{d}$ & 8 & - \\
\hline
\end{tabular}

Table 7-3. Ingestion dose conversion factors used in the Options Analysis.

\begin{tabular}{cc}
\hline Nuclide & $\begin{array}{c}\text { Conversion } \\
\text { Factor } \\
\text { (mrem/pCi) }\end{array}$ \\
\hline & \\
$\mathrm{C}-14$ & $2.10 \mathrm{E}-06$ \\
$\mathrm{U}-234$ & $2.60 \mathrm{E}-04$ \\
$\mathrm{U}-238$ & $2.45 \mathrm{E}-04$ \\
$\mathrm{~Np}-237$ & $3.90 \mathrm{E}-03$ \\
\hline
\end{tabular}


Table 7-4. Physical dimensions used in the Options Analysis.

\begin{tabular}{lcc}
\hline Parameter & $\begin{array}{c}\text { Ranges of Values } \\
\text { Used Composite } \\
\text { Analysis }\end{array}$ & $\begin{array}{c}\text { Value Used in } \\
\text { Options Analysis }\end{array}$ \\
\hline Width of disposal area $(\mathrm{m})$ & 500 to 1,000 & 500 \\
Length of disposal area $(\mathrm{m})$ & 180 to 500 & 490 \\
Density of aquifer $\left(\mathrm{kg} / \mathrm{m}^{3}\right)$ & 1,850 & 1,850 \\
Longitudinal dispersivity of aquifer $(\mathrm{m})$ & 9 & 9 \\
Transverse dispersivity of aquifer $(\mathrm{m})$ & 4 & 4 \\
Thickness of cover over waste $(\mathrm{m})$ & 1.5 & 1.5 \\
Thickness of waste $(\mathrm{m})$ & 2.5 & 2.5 \\
Distance to well from nearest edge of waste $(\mathrm{m})$ & 100 & 100 \\
Density of waste $\left(\mathrm{kg} / \mathrm{m}^{3}\right)$ & 1,600 & 1,600 \\
Amount of water percolating through the waste $(\mathrm{m} / \mathrm{yr})$ & 0.085 & 0.085 \\
Horizontal velocity of aquifer $(\mathrm{m} / \mathrm{yr})$ & 0.7 to 1,200 & 170 \\
Porosity of aquifer (unitless) & 0.06 & 0.1 \\
Porosity of vadose zone $(\mathrm{unitless})$ & 0.34 & 0.03 \\
Thickness of vadose zone $(\mathrm{m})$ & 45 & 170 \\
\hline
\end{tabular}

representative values generally within the ranges were chosen as a result of benchmarking PATHRAE with dose projections found in the Composite Analysis.

The PATHRAE code was also not able to model the wide ranges of vadose zone $K_{d}$ values presented in Table 7-5. As with the ranges in physical dimension parameters, representative bulk values used in the Options Analysis, also included in Table 7-5, were chosen by benchmarking the PATHRAE results with those of the Composite Analysis. Nuclide-specific $K_{d}$ values were chosen from within the ranges used in the Composite Analysis to represent the vadose zone as if it were a single homogeneous region. Calibration studies showed this representation to be accurate for the purpose of the Options Analysis. Similarly, Composite Analysis ranges in radionuclide solubility limits for the aquifer and the representative bulk values used in the Options Analysis are presented in Table 7-6.

\subsection{POTENTIAL MITIGATING ACTIONS}

Since the projected highest total dose over the 1,000 yrs beginning in 2020 to a hypothetical future member of the public from the sources of interest exceeds $30 \mathrm{mrem} / \mathrm{yr}$, the Composite Analysis guidance requires that an Options Analysis be conducted to identify alternatives that might be used to reduce future doses.

Within the RWMC, the contribution to projected doses from the waste placed in the active LLW disposal facility since 1984, and from projected placements to 2020 , appears to be very small. This can be seen by comparing the inventories of the four major radionuclides C-14, Np-237, U-234, and U-238 (Sections 3 and 4) in that waste to the total inventories used in the Composite Analysis. As a consequence of this observation, any actions that could be implemented to reduce the projected peak dose from all 
Table 7-5. Vadose zone distribution coefficients.

\begin{tabular}{ccc}
\hline Nuclide & $\begin{array}{c}\text { Range of Values Used in the } \\
\text { Composite Analysis (mL/g) }\end{array}$ & $\begin{array}{c}\text { Value Used in the } \\
\text { Options Analysis }\end{array}$ \\
\hline & & \\
C-14 & 0.1 to $7.6 \mathrm{E}-06$ & $1.00 \mathrm{E}-01$ \\
U-234 & 6 to $1.5 \mathrm{E}-04$ & $1.50 \mathrm{E}-04$ \\
U-238 & 6 to $1.5 \mathrm{E}-04$ & $1.50 \mathrm{E}-04$ \\
Np-237 & 8 to $2.0 \mathrm{E}-04$ & $2.00 \mathrm{E}-04$ \\
\hline
\end{tabular}

Table 7-6. Aquifer solubility limits.

\begin{tabular}{ccc}
\hline Nuclide & $\begin{array}{c}\text { Range of Values Used } \\
\text { in the Composite } \\
\text { Analysis (mole/L) }\end{array}$ & $\begin{array}{c}\text { Value Used in the } \\
\text { Options Analysis } \\
\text { (mole/L) }\end{array}$ \\
\hline C-14 & None & None \\
U-234 & $5.88 \mathrm{E}-04$ to $1.4 \mathrm{E}-02$ & $5.88 \mathrm{E}-04$ \\
$\mathrm{U}-238$ & $5.98 \mathrm{E}-04$ to $1.4 \mathrm{E}-02$ & $5.98 \mathrm{E}-04$ \\
$\mathrm{~Np}-237$ & $7.49 \mathrm{E}-08$ to $1.0 \mathrm{E}-01$ & $7.49 \mathrm{E}-08$ \\
\hline
\end{tabular}

sources at the RWMC must be viewed as being implemented for all the sources of contaminants at the RWMC. In other words, no actions taken to reduce doses from contaminants in the active LLW waste disposal facility will significantly reduce the peak dose projected by the Composite Analysis.

To identify effective mitigating actions for the RWMC, the specific conditions that are major causes of the annual doses calculated in the Composite Analysis were determined. These include:

- Relatively high rates of infiltration of precipitation into the waste (compared to what might be achieved), resulting in relatively high release of contaminants.

- Proximity of the critical receptor location to the RWMC after the end of institutional control, preventing dilution and dispersion of the contaminants released from the RWMC before they reach the receptor.

- The assumed loss of institutional control after $100 \mathrm{yrs}$ following closure of the LLW disposal facility at the RWMC. This allows members of the public to occupy the land relatively close to the source of contaminant release soon after the end of disposal operations.

Two other causes of high projected doses were also considered: (1) the large inventory of contaminants at the RWMC and (2) the relative ease with which contaminants can be removed by water infiltrating through the disposed waste. Mitigating the effects of these causes would, however, involve removing the waste and disposing of it elsewhere, or removing it, treating it, and redisposing of it at the RWMC. Those actions were eliminated as potential alternatives because relative to the other options these actions would be too costly and involve too much risk to workers. 
Finally, a legitimate approach to possibly reducing the peak projected doses in the Composite Analysis would be to reduce the uncertainties and conservatisms in that analysis. That approach was considered impractical at the present time.

The following sections describe the three potential mitigating actions that were analyzed: (1) reducing infiltration, (2) extending the boundary of the area controlled indefinitely, and (3) extending the time over which the whole of the INEEL (or at least the portion between the RWMC and the present INEEL boundary) is controlled.

\subsubsection{Reduced Infiltration}

The relatively high rate at which precipitation is assumed to infiltrate into the waste in the Composite Analysis (8.5 cm/yr) allows a considerable amount of water to come into direct contact with the disposed waste, compared to what would reach the waste if a better cover is used. This in turn allows a relatively high leach rate of radioactive contaminants from the waste and into the groundwater system. Once in the groundwater system, the contaminants can migrate to groundwater wells, where they become available for irrigation, watering of farm animals, and direct human uptake.

An improved cover design will reduce infiltration of precipitation through the waste. Since results indicating the effectiveness of this option are generally available from other studies at the INEEL, it was not necessary to develop a new site-specific cover design for the RWMC.

At least three techniques (a high degree of engineered barriers, enhanced vegetation, and extended cover thickness) can generally be effective in reducing the infiltration rate. Keck and Bhatt (1996) show a relatively low cost cover design incorporating an added $2.3 \mathrm{~m}(7.5 \mathrm{ft})$ of native soil over the existing cover cover and vegetating with crested wheatgrass can reduce the infiltration rate to $1 \mathrm{~cm} / \mathrm{yr}$ (more than a factor of eight lower than what is assumed in the Composite Analysis).

Table 7-7 shows the effect of the lower infiltration rate on the annual doses from the four radionuclides that contribute most of the dose within 1,000 yrs to the member of the public using water from a well $100 \mathrm{~m}(328 \mathrm{ft})$ downgradient from the RWMC boundary. The table shows the doses with the infiltration rate used in the Composite Analysis, the PATHRAE-predicted reductions in dose rates achieved using the lower infiltration rate, and the projected dose rates at the time of the peak dose rate (between yr 2020 and 3020). Note that it was conservatively assumed that no reduction was achieved in doses from radionuclides other than the four most significant ones. It was also assumed that no reduction in the dose from C-14 was achieved because, with the Composite Analysis parameter set, most of the dose from C-14 at 1,000 yrs comes from the $91 \%$ of the $C-14$ inventory that is contained in the activated metal and beryllium block. C-14 is released primarily by corrosion of the waste form, which is not affected by the rate of water infiltration.

The information in Table 7-7 demonstrates use of a cover that reduces the infiltration rate from the $8.5 \mathrm{~cm} / \mathrm{yr}$ assumed in the Composite Analysis to $1 \mathrm{~cm} / \mathrm{yr}$ lowers the projected peak groundwater dose from $58 \mathrm{mrem} / \mathrm{yr}$ to $20 \mathrm{mrem} / \mathrm{yr}$, or less. At $20 \mathrm{mrem} / \mathrm{yr}$, the dose is $66 \%$ below that estimated in the Composite Analysis. 
Table 7-7. Effect of reduced infiltration through use of a better cover.

\begin{tabular}{cccc}
\hline Radionuclide & $\begin{array}{c}\text { Baseline Dose Rate at } \\
\text { the Time of Maximum } \\
\text { Dose Rate (year 3020) } \\
\text { (mrem/yr) }\end{array}$ & $\begin{array}{c}\text { Reduction } \\
\text { Factor* }\end{array}$ & $\begin{array}{c}\text { Reduced Dose Rate at } \\
\text { the Time of } \\
\text { Maximum Dose Rate } \\
\text { (mrem/yr) }\end{array}$ \\
\hline C-14 & 12 & 1.00 & 12.0 \\
U-234 & 11 & 0.12 & 1.3 \\
U-238 & 18 & 0.11 & 2.0 \\
Np-237 & 14 & 0.12 & 1.7 \\
Other Mobile Nuclides & 3 & 1.00 & 3.0 \\
Total & 58 & & 20.0 \\
\hline * Reduction Factor = (Peak annual dose with better cover)/(Peak annual dose from the CA)
\end{tabular}

\subsubsection{Maintaining Institutional Control}

Another significant contributor to the dose determined in the composite analysis is the proximity of the projected well to the facility once institutional control ends. Extending the distance between the RWMC and the well used by the public provides more time for nuclide decay and dispersion in the groundwater. This would, however, require that the period of institutional control be extended more or less indefinitely, at least for the RWMC and a portion of the INEEL downgradient from it.

In the Composite Analysis it is assumed that a representative point near the RWMC where a member of the public can place a well after the end of institutional control is $100 \mathrm{~m}(328 \mathrm{ft})$ from the edge of the RWMC. The maximum annual dose was calculated for several distances between the well and the RWMC, up to $1,000 \mathrm{~m}(3,280 \mathrm{ft})$. The annual dose from the four radionuclides that the Composite Analysis indicates contribute almost all of the dose from the groundwater pathway 1,000 yrs after closure is reduced by moving the well away from the source of the contaminants. However, there is no benefit in extending the boundary of the controlled area beyond $500 \mathrm{~m}(1,640 \mathrm{ft})$. Table 7-8 shows the reductions in projected annual doses from the four key radionuclides achieved as a function of the distance maintained between the RWMC boundary and the boundary of the controlled area. Significant reductions in projected peak annual doses for the $1,000 \mathrm{yr}$ period of interest are achieved by maintaining institutional control over the area downgradient of the RWMC.

The analyses that were use to develop the results found in Table 7-8 focused on the four radionuclides that the Composite Analysis showed contributed to the peak dose at the $100 \mathrm{~m}(328 \mathrm{ft})$ well over the next 1,000 yrs. Two effects on projected doses from those radionuclides of moving the well farther from the source of contamination are seen: (1) the concentrations in the groundwater withdrawn through the well are reduced due to dispersion in the aquifer and, (2) because the concentrations of three of those four radionuclides (Np-237, U-234, and U-238) at the $100 \mathrm{~m}(328 \mathrm{ft})$ well are, at $1,000 \mathrm{yrs}$ after closure, still rising toward peak values, moving the well farther from the source will have an additional effect of reducing their concentrations in the groundwater. The latter effect will not, however, necessarily reduce peak doses at the alternative well locations from the mobile radionuclides other than C-14 (i.e., those radionuclides that were shown in the Composite Analysis to cause doses that rise rapidly, reach a peak value, and decline to very small values within 1,000 yrs). While contributions from the other mobile nuclides are lower than the total annual dose from the four most important radionuclides at the $100 \mathrm{~m}$ (328 ft) well at 1,000 yrs, they may become the dominant cause of dose as the distance to the well is increased. In the calculations used to develop Table 7-8, the annual doses from the other mobile radionuclides were assumed to be the same at 1,000 yrs, regardless of how far from the source the well is located. 
Table 7-8. Effect of maintaining institutional control over part of the INEEL.

Distance Between RWMC and the Well (m)

\begin{tabular}{lcccccc} 
& 100 & 200 & 300 & 400 & 500 & 1,000 \\
\hline $\begin{array}{l}\text { Annual Dose at } \\
1,000 \text { years } \\
\text { (mrem/yr) }\end{array}$ & 58 & 17 & 9.7 & 5.3 & 3.3 & 3.0 \\
$\begin{array}{l}\text { Reduction in } \\
\text { Annual Dose at } \\
1,000 \text { years } \\
\text { (mrem/yr) }\end{array}$ & - & 41 & 48 & 53 & 55 & 55 \\
\hline
\end{tabular}

\subsubsection{Extend the Time of Institutional Control}

Extending the duration of the institutional control period will keep the critical member of the public from getting close to the RWMC until later, thereby allowing radioactive decay to reduce the dose. In the Composite Analysis the time of compliance with the dose limits given in the DOE guidance was taken to be 1,000 yrs. The Composite Analysis also shows that if institutional control is maintained indefinitely (i.e., the public is excluded from the existing boundaries of the INEEL), the highest projected annual dose to the critical member of the public in the next $1,000 \mathrm{yrs}$ is much less than $30 \mathrm{mrem} / \mathrm{yr}$, without having to take any further actions to reduce doses.

If institutional control were maintained over the INEEL, or over the portion of INEEL between the RWMC and the current Site boundary to the south and southwest, to the effect that members of the public would be excluded from occupying that area for 999 yrs, the highest dose to a hypothetical member of the public over the next 1,000 yrs would not be reduced. This follows from the fact that the projected dose to the critical member of the public is still increasing in the year 3000 and will continue to increase for many years afterwards.

\subsection{POPULATION DOSE}

In order to perform an ALARA analysis an estimate must be made of the population dose in the absence and presence of the alternative actions considered. The first step is to estimate a population dose in the absence of any activities not assumed in the Composite Analysis.

Consistent with the ALARA analysis described in Maheras et al., 1997, the peak individual annual dose of $58 \mathrm{mrem} / \mathrm{yr}$ calculated in the Composite Analysis was assumed to be received by 10 people who

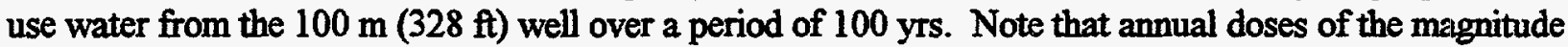
indicated will not be received until the last few years of the 1,000-yr period of interest in the Composite Analysis. The population dose for the case where no activities are implemented to reduce doses from those estimated in the Composite Analysis is therefore approximately 58 person-rem. Projected annual doses to individuals when actions are taken to reduce the peak individual dose translate into population doses in the same manner. A peak annual individual dose of $20 \mathrm{mrem} / \mathrm{yr}$ indicates a population dose of about 20 person-rem, and so forth. 


\subsection{COST ESTIMATES}

To conduct an ALARA analysis, estimates of costs to conduct activities that reduce doses are also needed. This section provides cost estimates for implementing the actions described in Sections 7.3.1 and 7.3.2. The action described in Section 7.4.3 (maintaining control part of the site between the RWMC to the present site boundary for a certain period of time) is considered to be of no value in reducing doses to the exposed public unless it is carried out more or less indefinitely. If control is carried out for very long periods of time, the action becomes similar to the action described in Section 7.3.2.

\subsubsection{Cost of Reduced Infiltration}

An estimate of the additional cost of constructing the thicker cover was derived from (Keck and Bharr 1996). Appendix $G$ of that document indicates that such a cover over the 1.6 hectare (4 acre) active LLW disposal facility is estimated to cost $\$ 4.1$ million. The Subsurface Disposal Area (SDA) at the RWMC encompasses 39 hectares ( 97 acres). Reducing the per acre cost by half allows for efficiency in covering a larger area. All of the 39 hectares (97 acres) may not have to be covered. The cost estimate for installing an improved low infiltration cover for the RWMC is about $\$ 50$ million.

\subsubsection{Cost of Maintaining Institutional Control}

An estimate of the cost of maintaining institutional control over part of the Site indefinitely to keep members of the public farther away from the RWMC involves two main elements: (1) the cost (value) of the land that otherwise could have been sold to the public, and (2) the cost of active maintenance, such as fencing and occasional patrolling, that might be conducted for some time at the controlled area.

To estimate the cost of active maintenance, the additional cost of fencing the perimeter of the larger area that must be kept under control, replacing the extra fence every $10 \mathrm{yrs}$, and checking the fence every week for the first 100 yrs after closure was estimated. After the first 100 yrs, the cost of maintaining, replacing and patrolling the entire fence encircling the RWMC and the additional controlled area was estimated. The present value (in 1998 dollars) of a care fund sufficient to pay for these activities for an indefinite time into the future (in other words, perpetually) was estimated based on a real rate of return to the fund of $3.5 \%$ per yr. Note that the $3.5 \%$ real rate of return is conservatively lower than the $5 \%$ rate assumed in Keck and Bhatt (1996).

The present value of that care fund reaches a steady state value as the assumed duration of care approaches about 300 yrs after closure. In other words, for durations longer than 300 yrs the fund is sufficient to pay all costs from the earnings of the fund, and care can be funded in perpetuity. It is that steady state present value of the care fund that is used in this analysis.

To calculate an area that must remain under control and the length of the fencing, it was assumed that a swath $1,500 \mathrm{~m}(4,921 \mathrm{ft})$ wide downgradient from the RWMC must be retained for as far downgradient as the closest tolerable public well. The area of the RWMC [39 hectares ( 97 acres)] will also be retained. Table 7-9 shows the areas that must be retained to keep the public well farther from the

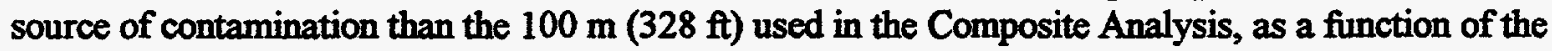
distance to the nearest allowable well. The cost of that action was calculated using an estimated 1998 cost of land at the INEEL of $\$ 200$ per acre. The table also shows the estimated total cost, for both land 
Table 7-9. Areas to be retained and the present value of associated costs.

Distance to a

Public Well from

RWMC

Boundary

Area to be

Retained

Present Value of Incremental

Costs (thousands of 1998

Estimated Reduction

in Population

\begin{tabular}{cccc}
$(\mathrm{m})$ & (Acres) & dollars)* & (person-rem) \\
\hline 200 & 171 & 202 & 41 \\
300 & 208 & 234 & 48
\end{tabular}

* Present value costs for the associated care costs are based on a 3.5 percent real rate of return.

retention and care of the controlled area, and the reduction in population dose that is calculated from the reductions in individual doses shown in Table 7-8.

The distances to the public well in Table 7-9 do not exceed $300 \mathrm{~m}$ (984 ft) because, as explained in Section 7.3.2, the analysis of effects of extending institutional control are only valid out to that distance. Beyond $300 \mathrm{~m}$ (984 $\mathrm{ft}$ ), doses from the mobile nuclides will probably dominate and the analysis did not investigate the doses from those nuclides.

\subsection{ALARA ANALYSIS}

The DOE Composite Analysis guidance indicates that an action to reduce potential population dose can be considered cost effective if between $\$ 1,000$ and $\$ 10,000$ will reduce the dose by one person-rem. The cost estimate provided in Section 7.5.1 indicates that a population dose reduction of at least 5,000 person-rem would be needed to justify the $\$ 50$ million cost of placing the improved cover over the RWMC that reduces the infiltration rate. Since the estimated population dose is only 58 person-rem if no further action is taken, it is concluded that adding a better cover to the entire RWMC is not cost effective in reducing the population dose.

The estimated costs and reductions in population doses given in Table 7-8 and Table 7-9 indicate that it should be cost effective to retain a portion of the INEEL under DOE or other agency control indefinitely to keep the public away from the RWMC. The cost of the actions needed to reduce the peak dose rates are less than half that allowed using a figure of $\$ 10,000$ per person-rem. 


\section{REFERENCES}

Abbott, M. L., 1997a, Revised Report on NRF Expended Resin Waste Activity Inventories, MLA9-97, LMITCO Interdepartmental Communication.

Abbott, M. L., 1997b, Revised Report on NRF Core Structural Waste Activity Inventories, MLA8-97, LMITCO Interdepartmental Communication.

Abbott, M. L., 1998, LMITCO Interdepartmental Communication from to J. A. Logan, Estimated C-14 Inventory in TRA Resin Shipments to the RWMC, April 14, 1998, MLA-03-98.

AEC, 1970, Policy Statement Regarding Solid Waste Burial, Immediate Action Directive No. 0511-21, U.S. Atomic Energy Commission, March 20.

Baes, C. F. et al., 1984, A Review and Analysis of Parameters for Assessing Transport of Environmentally Released Radionuclides through Agriculture, ORNL-5786.

Baes, C. F. III and T. H. Orton, 1979, "Productivity of Agricultural Crops and Forage, $Y_{v}$ " in A Statistical Analysis of Selected Parameters for Predicting Food Chain Transport and Internal Dose of Radionuclides, NUREG/CR-1004, November.

Banaee, J. and P. K. Nagata, 1996, Interdepartmental Communication to D. J. Jorgensen, Underground Corrosion of Austentic Stainless Steel and Nickel-based Alloys at the Radioactive Waste Management Complex, PKN-02-96, EG\&G Idaho, Inc.

Barnard, C. J., 1992, Verification and Updating of the Radioactive Waste Management Information System for the Inactive TRU and non-TRU Pits and Trenches at the Radioactive Waste Management Complex Subsurface Disposal Area, EGG-ER-10519, Rev. 0, November.

Baumer, A. R. II, S. C. Flynn, and C. S. Watkins, Quality Assurance Project Plan for Waste Area Groups 1, 2, 3, 4, 5, 6, 7, and 10, INEL-95/0086, March 1995.

Becker, B. H., 1997, Selection and Development of Models Used in the Waste Area Group 7 Baseline Risk Assessment, INEL/EXT-97-00391, Lockheed Martin Idaho Technologies Company, May.

Becker, B. H., T. A. Bensen, C. S. Blackmore, D. E. Burns, B.N. Burton, N. L. Hampton, R. M. Huntley, R. W. Jones, D. Jorgensen, S. O. Magnuson, C. Shapiro, R. L. VanHorn, 1996, Work Plan for Operable Unit 7-13/14 Waste Area Group 7 Comprehensive Remedial Investigation/Feasibility Study, INEL-95/0343, Lockheed Martin Idaho Technologies Company, May.

Becker, B. H., J. D. Burgess, K. J. Holdren, D. K. Jorgensen, S. O. Magnuson, and A. J. Sondrup, 1998, Interim Risk Assessment and Contaminant Screening for the Waste Area Group 7 Remedial Investigation, DOE/ID-10569, Lockheed Martin Idaho Technologies Company, Draft Rev. 2, March. 
Becker, B. H. and S. O. Magnuson, 1998, Sensitivity Simulation Results for Models Used to Support both the WAG7 IRA and LLW CA, EDF-ER-032, Lockheed Martin Idaho Technologies Company.

Bradley, T. M., 1998, Letter from Bradley, Manager Naval Reactors Idaho Branch Office, to J. T. Case, Manager Waste Management Programs, Additional Information on Past and Projected Future Radioisotope Inventory from Noval Reactors Facility and Comments on the Assumptions Used in the Radioactive Waste Management Complex Performance Assessment, February 27, 1998, NR:IBO-98/034.

Burgess, J. D., 1996, Tritium and Nitrate Concentrations at the RWMC, Engineering Design File EDF-ER-024, INEL-96/204, Lockheed Martin Idaho Technologies Company.

Burns, D. E., B. H. Becker, R. M. Huntley, C. A. Loehr, S. M. Rood, P. Sinton, and T. H. Smith, 1994, Revised Preliminary Scoping Risk Assessment for Waste Pits, Trenches, and Soil Vaults at the Subsurface Disposal Area, Idaho National Engineering Laboratory, EG\&GER-11395, EG\&G Idaho, Inc., June.

Burns, D. E., K. M. Davis, S. C. Flynn, J. F. Keck, N. L. Hampton, A. H. Owen, and R. L. VanHorn, 1997, Comprehensive Remedial Investigation/Feasibility Study for the Test Reactor Area Operable Unit 2-13 at the Idaho National Engineering and Environmental Laboratory, DOE/ID-10531, Lockheed Idaho Technologies Company, Idaho Falls, ID.

Carboneau, M. L., 1998 Interdepartmental Communication to J. A. Logan, Reassessment of Neutron-Activation-Product Curies Sent from EBR-II to Disposal at the RWMC, February 27, 1998, MLC-01-98.

DOE, 1987, Environmental Assessment: Fuel Processing and Restoration at the Idaho National Engineering Laboratory, DOE/EA-0306.

DOE, 1996, Guidance for a Composite Analysis of the Impact of Interacting Source Terms on the Radiological Protection of the Public from Department of Energy Low-Level Waste Disposal Facilities, April.

Dicke, C. A., 1997, Carbon-14 Distribution Coefficients Measured from Batch Experiments on SDA Sediments, INEEL/INT-98-00068, EDF-RWMC-1011, Lockheed Martin Idaho Technologies Company, May.

Dicke, C. A., 1998, Distribution Coefficients and Contaminant Solubilities for the Waste Area Group 7 Baseline Risk Assessment, INEL/EXT-97-00201, Lockheed Martin Idaho Technologies Company, May.

EG\&G, 1985, A History of the Radioactive Waste Management Complex at the Idaho National Engineering Laboratory, WM-F1-81-003, EG\&G Idaho Inc., Rev. 3, July.

EPA, 1989a, Risk Assessment Guidance for Superfund, Volume I, Human Health Evaluation Manual (Part A), EPA540/1-89/002. 
EPA, 1989b, Risk Assessments Methodology, Environmental Impact Statement, NESHAPs for Radionuclides, Background Information Document - Volume 1, EPA/520/1-89-005.

EPA, 1987, Data Quality Objectives for Remedial Response Activities, Development Process, EPA540/g-87/003, U.S. Environmental Protection Agency, March 1987.

Holdren, K. J., R. G. Filemyr, and D. W. Vetter, 1995, Remedial Investigation/Feasibility Study Report for Operable Units 5-05 and 6-01 (SL-1 and BORAX-I Burial Grounds), INEL95/0027, Lockheed Idaho Technologies Company, Idaho Falls, ID.

Honeycutt, T.K., 1996, LMITCO Interdepartmental Communication, Factors Controlling Radionuclide Release for Ion Exchange Resin, Lockheed Martin Idaho Technologies Company, Draft.

Honeycutt, T. K., 1998, LMITCO Interdepartmental Communication, Summary of Radionuclide Source Term Refinement for ANL-W, NRF, TRA, and SMC Waste Streams, May 5 , 1998.

Keck, K. N. and R. N. Bhatt, 1996, Preliminary Closure Plan for the SDA Active Low-Level Radioactive Waste Disposal Area, INEL-96/0215, LMTTCO, Idaho Falls, ID.

LITCO, 1995, Record of Decision: Stationary Low-Power Reactor-1 and Boiling Water Reactor Experiment-I Burial Grounds (Operable Units 5-05 and 6-01), and 10 No Action Sites (Operable Units 5-01, 5-03, 5-04, and 5-11), INEL-95/0282.

LMITCO, 1995a, A Comprehensive Inventory of Radiological and Nonradiological Contaminants in Waste Buried in the Subsurface Disposal Area of the INEL RWMC During the Years 1952-1983, INEL-95/0310 (formerly EGG-WM-10903), Lockheed Martin Idaho Technologies Company, Rev. 1, August.

LMITCO, 1995b, A Comprehensive Inventory of Radiological and Nonradiological Contaminants in Waste Buried or Projected to Be Buried in the Subsurface Disposal Area of the INEL RWMC During the Years 1984-2003, INEL-95/0135, Lockheed Martin Idaho Technologies Company, Rev. 1, August.

Magnuson, S. O., 1995, Inverse Modeling for Field-Scale Hydrologic and Transport Parameters of Fractured Basalt, INEL-95/0637, Lockheed Martin Idaho Technologies Company, Idaho Falls, ID.

Magnuson, S. O., 1996, LITCO Interdepartmental Communication to D. K. Jorgensen, Transmittal of TETRAD Benchmarking Report, SOM-01-96, Lockheed Martin Idaho Technologies Company, Idaho Falls, ID.

Magnuson, S. O., and A. J. Sondrup, 1998, Development, Calibration, and Predictive Results of a Simulator for Subsurface Pathway Fate and Transport of Aqueous and Gaseous Phase Contaminants in the Subsurface Disposal Area at the Idaho National Engineering and Environmental Laboratory, INEL-97/00609, Lockheed Martin Idaho Technologies Company, Draft Rev. 1, March. 
Maheras, S. J., A. S. Rood, S. O. Magnuson, M. E. Sussman, and R. N. Bhatt, 1994, Radioactive Waste Management Complex Low-Level Waste Radiological Performance Assessment, EGG-WM-8773, EG\&G Idaho, Inc., May.

Maheras, S. J., A. S. Rood, S. O. Magnuson, M. E. Sussman, and R. N. Bhatt, 1997, Addendum to Radioactive Waste Management Complex Low-Level Waste Radiological Performance Assessment (EGG-WM-8773), INEEL/EXT-97-00462, LMITCO, April.

Martian, P., 1995, UNSAT-H Infiltration Model Calibration at the Subsurface Disposal Area, Idaho National Engineering Laboratory, INEL-95/0596, Lockheed Martin Idaho Technologies Company.

Merrell, G. B., V. C. Rogers, and T. K. Chau, 1995, The PATHRAE-RAD Performance Assessment Code for the Land Disposal of Radioactive Wastes, RAE-9500/2-1, Rogers \& Associates Engineering Corporation, Salt Lake City, UT.

Nagata, P. K., 1993, Interdepartmental Communication to T. H. Smith, Letter Report on Tritium Release from Buried Beryllium Reflectors, EG\&G Idaho, Inc., December 22.

Nagata, P. K., 1997, LMITCO Interdepartmental Communication to J. A. Logan, Literature Search on Underground Corrosion Rates of Austenitic Steels, September 22, PKN-15-97.

NCRPM (National Council on Radiation Protection and Measurements), 1984, Radiological Assessment: Predicting the Transport, Bioaccumulation, and Uptake by Man of Radionuclides Released to the Environment, NCRP Report No. 76, March.

NCRPM (National Council on Radiation Protection and Measurements), 1985, A Handbook of Radioactivity Measurements Procedures, NCRP Report No. 58, $2^{\text {nd }}$ ed., February 1, 1985.

$\mathrm{Ng}, \mathrm{Y} . \mathrm{C}$. et al., 1978, Methodology for Assessing Dose Commitment to Individuals and to the Population from Ingestion of Terrestrial Foods Contaminated by Emissions from a Nuclear Fuel Reprocessing Plant at the Savannah River Plant, UCID-17743, Lawrence Livermore Laboratory, March.

NRC, 1977, Regulatory Guide 1.109 Calculation of Anmual Doses to Man From Routine Releases of Reactor Effluents for the Purpose of Evaluating Compliance With 10 CFR Part 50 Appendix I, Revision 1.

Orr, B. R, and L. D. Cecil, 1991, Hydrologic Conditions and Distribution of Selected Chemical Constituents in Water, Snake River Plain Aquifer, Idaho National Engineering Laboratory, Idaho, 1986 to 1988, DOE/ID-22096, U.S. Geological Survey Water Resource Investigations Report 91-4047, Idaho Falls, ID.

Peterson, H. T. Jr., 1983, "Terrestrial and Aquatic Food Chain Pathways," in Radiological Assessment - A Textbook on Environmental Dose Analysis, J.E. Till and H.R. Meyer (eds.), NUREG/CR-3332. 
Plansky, L. E. and S. A. Hoiland, 1992, Analysis of the Low-Level Waste Radionuclide Inventory for the Radioactive Waste Management Complex Performance Assessment, EGG-WM9857, Rev. 1, June.

Rodman, G. R., and F. E. Stoll, 1994, Decontamination and Decommissioning Plan for the Borax-V Facility, EGG-ER-10900, Revision 1.

Rodriguez, R. R., A. L. Schafer, J. M. McCarthy, P. Martian, D. E. Bums, D. E. Raunig, N. A. Burch, and R. L. VanHorn, August, 1996, Comprehensive RIFS for the Idaho Chemical Processing Plant OU 3-13 at the INEL-RI/BRA Report (Draft)," DOE/ID-10534, Lockheed Martin Idaho Technologies Company, Rev. 0.

Rood, A. S., 1993, Software Verification and Validation Plan for the GWSCREEN Code, EGGGEO-10798, EG\&G Idaho, Inc., Idaho Falls, ID.

Rood, A. S., 1994, GWSCREEN: A Semi-Analytical Model for the Assessment of the Groundwater Pathway from Surface or Buried Contamination, Version 2.0, Theory and User's Manual, EGG-GEO-10797, EG\&G Idaho, Inc., June.

Rupp, E. M., 1980, "Age-Dependent Values of Dietary Intake for Assessing Human Exposures to Environmental Pollutants," Health Physics, 39, pp. 151-163.

Schnitzler, B. G., 1995, LMITCO Interdepartmental Communication to M. M. Garland, Radionuclide Inventories of Advanced Test Reactor Outer Shim Control Cylinder and Reflector Block Components, August 21, 1995, BGS-12-95.

Shook, G. M., 1995, Development of an Environmental Simulator from Existing Petroleum Technology, INEL-94/0283, Lockheed Martin Idaho Technologies Company, Idaho Falls, ID.

Shook, G. M., and Faulder, D. D., 1991, Validation of a Geothermal Simulator, EG\&G Report, \#EP-9851, October 1991.

Smith, C. S. and C. A. Whitaker, 1993, independent Verification and Limited Benchmark Testing of the GWSCREEEN Computer Code Version 2.0, EGG-GEO-10799, EG\&G Idaho, Inc., Idaho Falls, ID.

Sterbentz, J. W., 1998, LMITCO Interdepartmental Communication to J. A. Logan, Radionuclide Inventories for Advanced Test Reactor Core Components (DRAFT), April 1, 1998, JWS-0498.

Sullivan, T. M., 1993, DUST Data Input Guide, NUREG/CR-6041, April 1993.

Vinsome, P. K. W., and G. M. Shook, 1993, "Multi-Purpose Simulation," Journal of Petroleum Science and Engineering, Vol. 9, pp. 29-38.

Wood, T. R, and G. T. Norrell, 1996, Integrated Large-Scale Aquifer Pumping and Infiltration Tests, Groundwater Pathways OU 7-06, Summary Report, INEL-96/0256, Lockheed Martin Idaho Technologies Company, Rev. 0. 